Gunter Camilo Dablas de Oliveira

\title{
Uma Contribuição para Circuitos Eletrônicos de Medidores de Radiações Ultravioleta para Lentes
}

Dissertação de Mestrado apresentada à Escola de Engenharia de São Carlos da Universidade de São Paulo

Curso de Engenharia Elétrica com ênfase em Eletrônica

ORIENTADORA: Profa. Dra. Liliane Ventura 
Data da Defesa:

\section{Banca Examinadora}

Prof. Dr.:

Julgamento:

Assinatura:

Prof. Dr.:

Julgamento:

Assinatura:

Prof.Dr.:

Julgamento: Assinatura:

Prof. Dr.:

Julgamento:

Assinatura:

Prof. Dr.:

Julgamento: Assinatura: 
Dedico esta dissertação a minha esposa e filhos. 


\section{AGRADECIMENTOS}

Agradeço:

À minha esposa e filhos por toda a dedicação e paciência durante este período; À Profa. Dra. Liliane Ventura pela orientação;

Aos amigos do LIO, Nelson e Victor, pela troca de informações constante durante este período;

Ao Prof. Dr. Lino Misoguti pelo empréstimo do espectrofotômetro para nossas medidas e pela sua sempre presteza com o nosso grupo;

Ao Rui Bertho, pela prontidão nas confecções das peças mecânicas;

Ao Prof. Sidney Júlio de Faria e Sousa pelas críticas e discussões construtivas;

Ao Prof. Edson Gesualdo pela constante colaboração.

À pós-graduação por todo o suporte neste período, principalmente ao Prof. Geraldo da Costa Martins, coordenador da pós;

Às secretárias da pós, neste período todo;

Aos funcionários do Departamento de Engenharia Elétrica da Escola de Engenharia de São Carlos - USP, pelo suporte sempre presente;

À CAPES pelo suporte financeiro. 
Sumário

1. Resumo ................................................................... 10

2. Abstract ................................................................ 12

3. Introdução ............................................................ 13

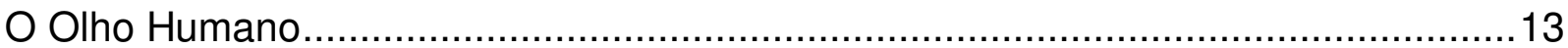

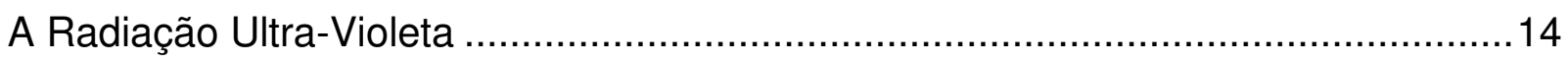

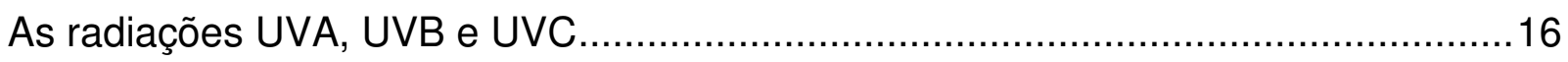

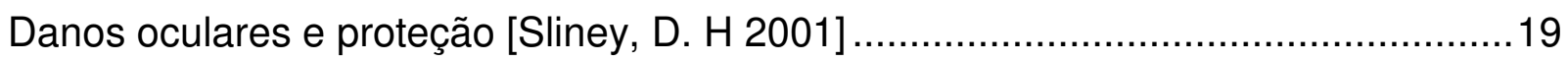

Riscos da Radiação Ultravioleta [NBR15111, 2004] ...........................................24

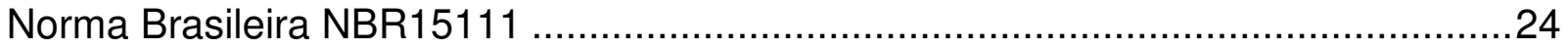

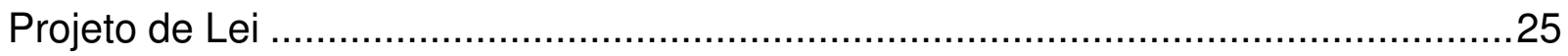

4. Materiais e Métodos ...................................................... 26

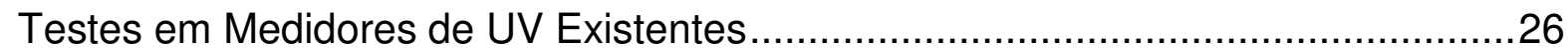

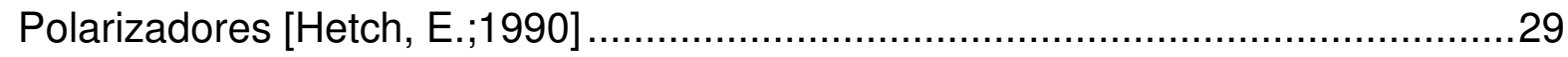

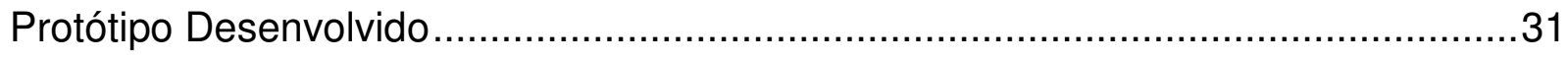

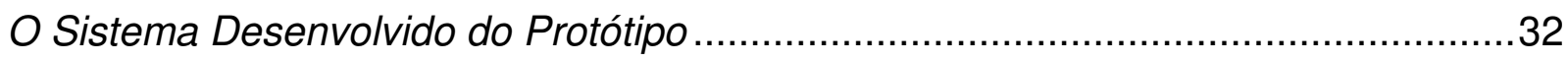

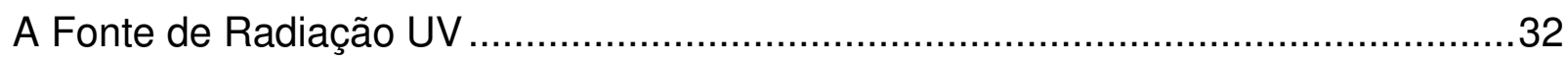

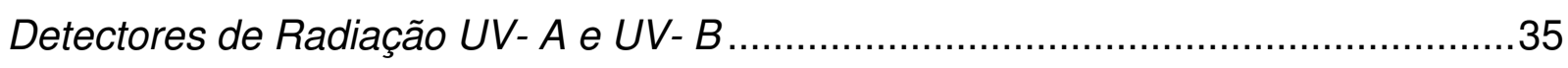

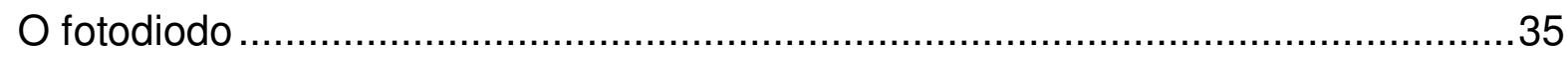

5. O Sistema Eletrônico ..................................................... 38

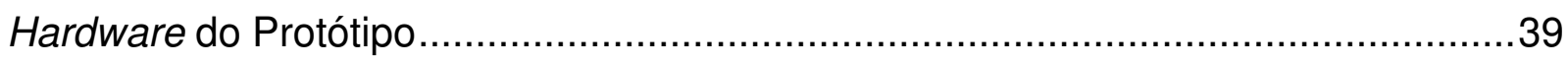

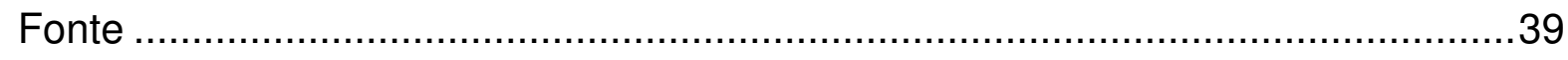

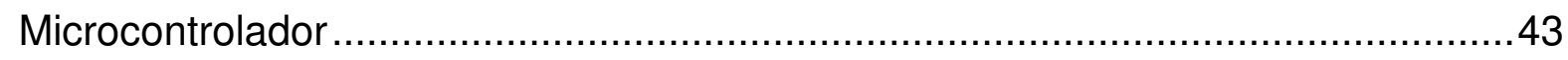

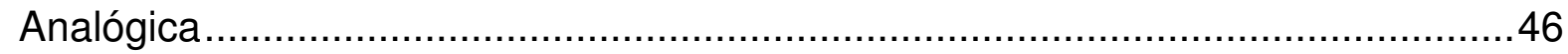

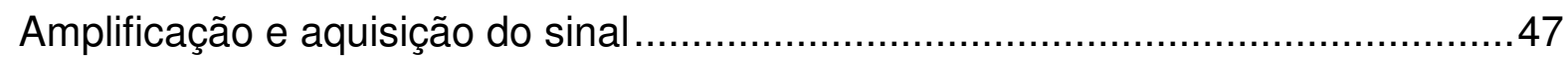

6. Desenvolvimento do Protótipo....................................... 56

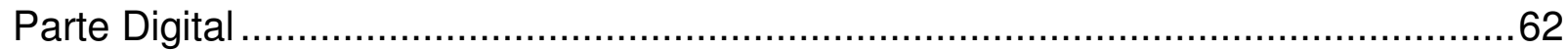

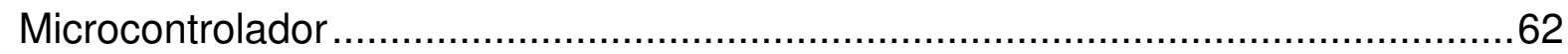

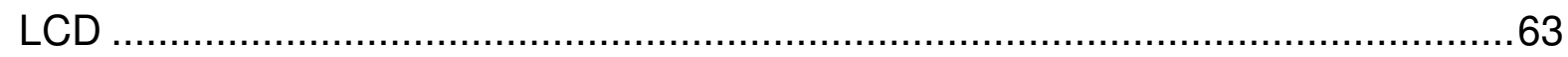

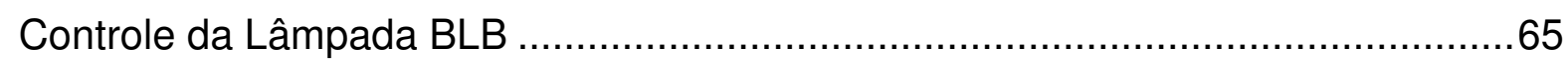

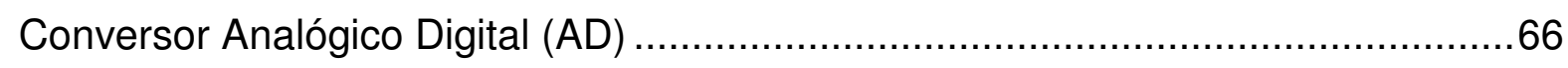

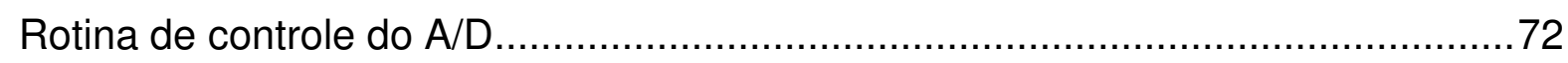

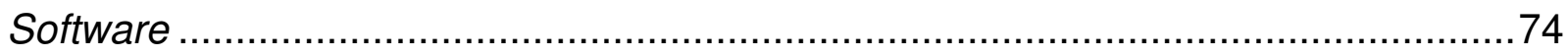




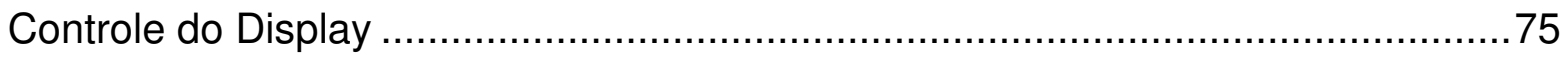

Controle do Conversor A/D ......................................................................... 77

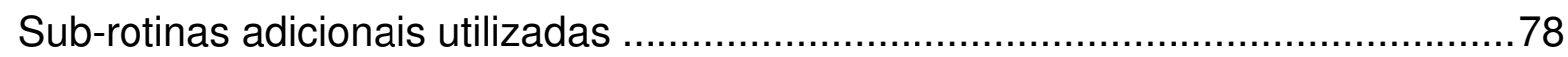

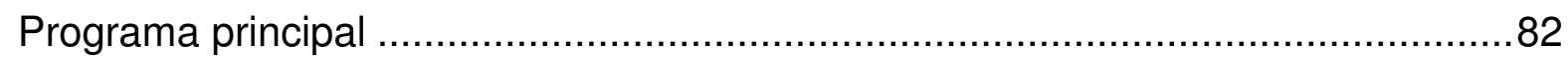

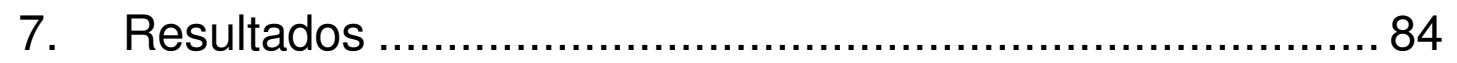

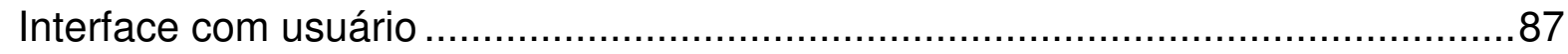

Calibração do sistema .......................................................................... 90

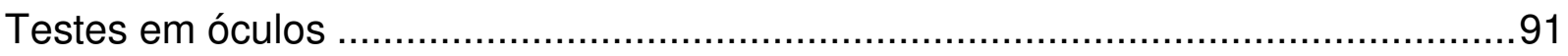

8. Discussão e Conclusão ........................................... 92

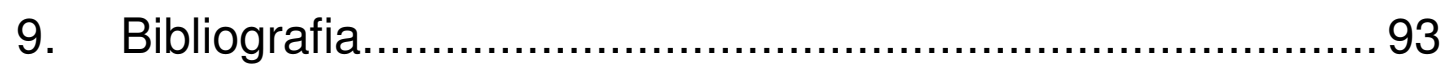




\section{Índice de figuras}

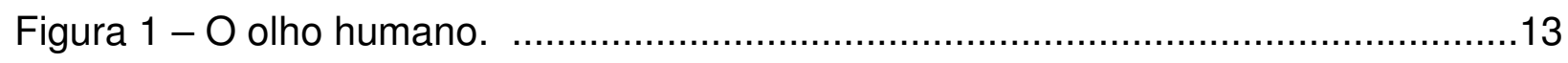

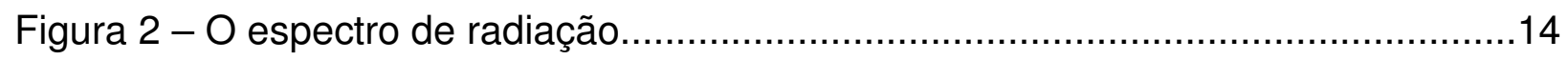

Figura 3 - O espectro de irradiação solar..........................................................15

Figura 4: Espectro de radiação eletromagnética ...................................................18

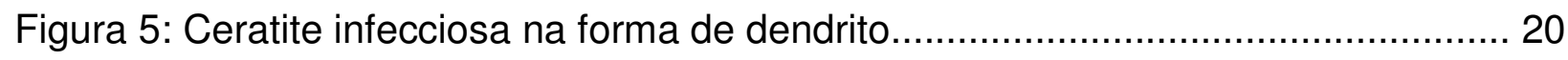

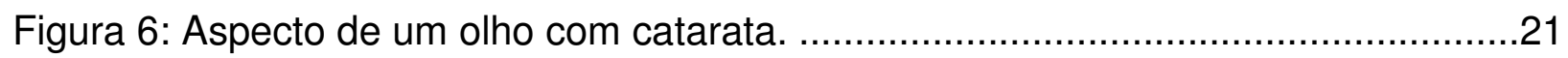

Figura 7 - Os raios UV e a estrutura ocular. Retirada do "website" ..............................23

Figura 8 - O funcionamento da absorção e proteção aos raios UV..............................23

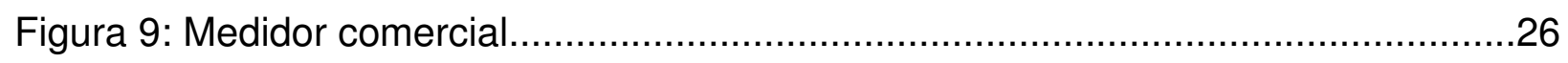

Figura 10: Diagrama em blocos do medidor U.V................................................. 27

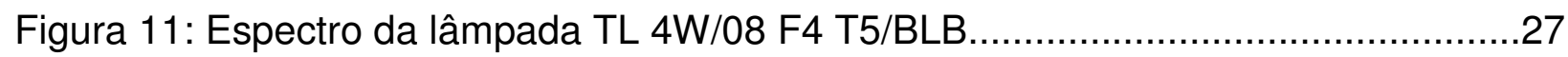

Figura 12: Botão para ajuste do fundo de escala................................................. 27

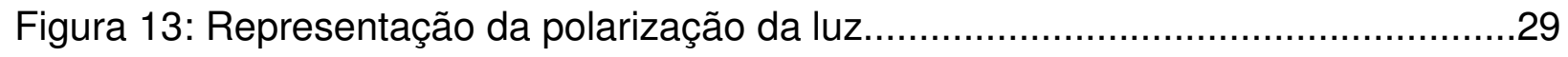

Figura 14: Análise da luz, com dois filtros polarizadores dispostos ortogonalmente.....30

Figura 15: Medidas efetuadas com polarizadores: (a) paralelos; (b) ortogonais; (c) a

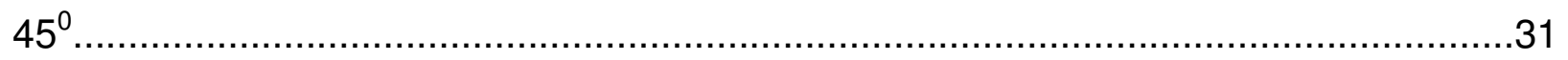

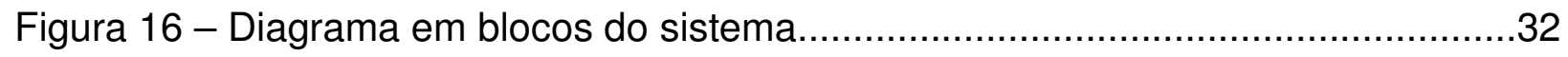

Figura 17: Lâmpadas BLB: 1. Masterkey modelo BLB 2U 9W; 2. Light Express BLB 4W e; 3. Sankyo denki BLB 6W.

Figura 18 - Espectros de emissão das Lâmpadas BLB: 1. Masterkey modelo BLB 2U 9W; 2. Light Express BLB 4W e; 3. Sankyo Denki BLB 6W......................................

Figura 19 - Espectro de sensibilidade dos dois sensores JEC 0.1A (UVA) e JEC 0.1B

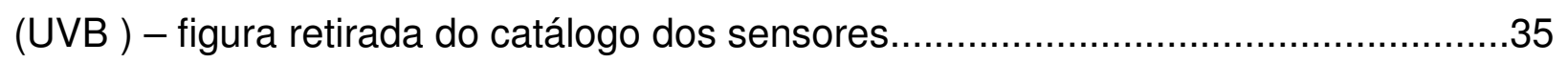

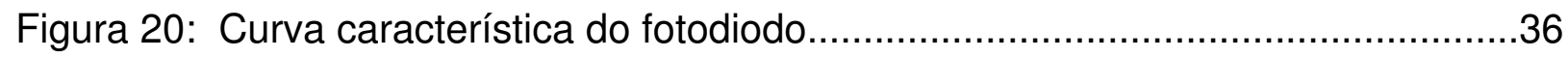

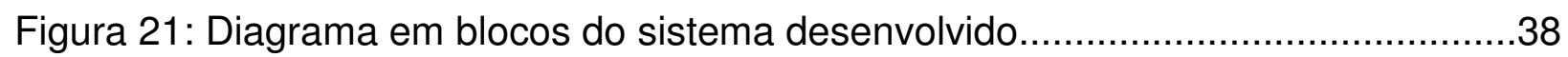

Figura 22: Esquema geral de ligações do medidor.................................................40

Figura 23: Diagrama de blocos da fonte de alimentação..............................................40

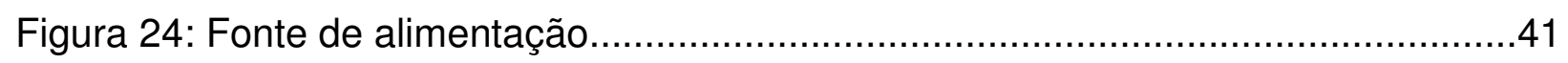

Figura 25: Saída de um retificador de onda completa para uma entrada senoidal imagem retirada do osciloscópio Tektronix TDS 220 
Figura 26: Saída do retificador após filtragem - - imagem retirada retirada do osciloscópio Tektronix TDS 220.

Figura 27: Saída do retificador após o regulador de tensão - imagem retirada retirada do osciloscópio Tektronix TDS $220 .$. 42

Figura 28: Descrição da pinagem do 89S52. 43

Figura 29: Circuito de reset automático e forçado. .44

Figura 30: Esquema de interligações do microcontrolador. 46

Figura 31 - Esquemático do acionamento da lâmpada BLB.

Figura 32: Esquema de interligação entre conversor corrente tensão e amplificador. 48

Figura 33: Diagrama interno do cornversor A/D ADC 0803...................................49

Figura 34: Gerador de clock do ADC0803.......................................................50

Figura 35: Esquema de interligação do ADC0803...........................................50

Figura 36: Conversor corrente - tensão.......................................................... 51

Figura 37: Esquema do conversor corrente tensão com fotodiodo.......................... 52

Figura 38 - Filtro Ativo Passa Baixa.......................................................... 53

Figura 39: Esquemático do amplificador não inversor.........................................54

Figura 40 - Gráfico de Irradiância x Tensão do fotodiodo...................................... 56

Figura 41 - Esquemático dos estágios amplificadores....................................... 57

Figura 42 - Estágio 1 : Conversor corrente - tensão........................................58

Figura 43 - Estágio 2 : Filtro Passa Baixa............................................................58

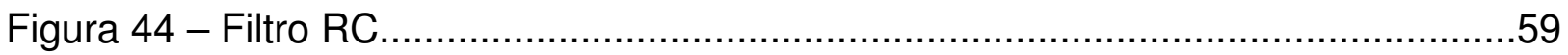

Figura 45: Estágio 3: Amplificador Integrador Miller...........................................59

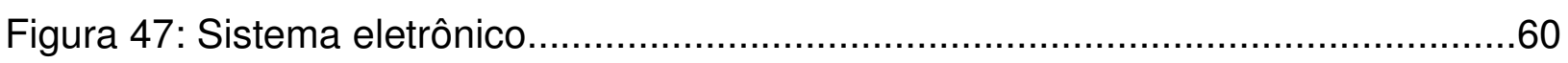

Figura 48: Caixa funcional, sistema eletrônico e lâmpada BLB...............................61

Figura 49 - Pinagem do microcontrolador AT89S52..........................................62

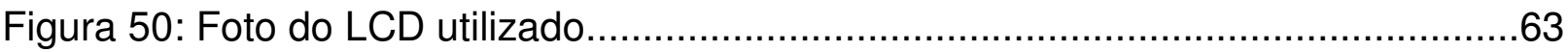

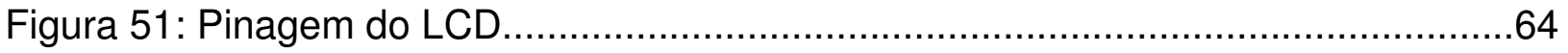

Figura 52 - Esquemático do acionamento da lâmpada BLB...................................66

Figura 53 - Pinagem do conversor ADC0808 ..............................................6

Figura 54 - Diagrama de tempos do conversor A/D utilizado...................................69

Figura 55 - Tensão de entrada versus valor digital na saída do conversor AD............69

Figura 56: Diagrama do circuito definitivo do medidor de ultravioleta..........................71

Figura 57: Saída do software versus entrada no AD.................................................73 


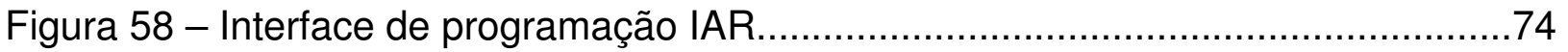

Figura 60: Variação da intensidade de luz, com a variação de corrente de saída -

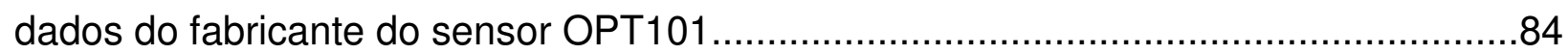

Figura 61: Circuito de deteç̧ão e amplificação de sinal...........................................85

Figura 62 - Display com a mensagem de inicialização do sistema............................87

Figura 63 - Display com a mensagem de calibração do sistema...................................88

Figura 64 - Display exibindo a seleção de teste.................................................. 88

Figura 65: Parte do circuito digital utilizado na simulação.........................................89

Figura 66: Medidas realizadas com polarizador no sistema para calibração..................90 


\section{Índice de Tabelas}

TABELA 1: Efeitos da radiação solar sobre o olho humano (adaptado de Vergaz, 2002). 19

TABELA 2: Valores de Transmitâncias para Filtros Solares de Uso em Óculos - dados retirados na norma NBR15111 25

TABELA 3: Valores de Transmitâncias para Filtros Solares de Uso em Óculos - dados retirados na norma NBR15111. .53

TABELA 4: Funções de cada pino do LCD JHD 162A.........64

TABELA 5: Estado lógico nas linhas de controle do LCD .65

TABELA 6: Pinagem e funções do ADC0808..........67

TABELA 7: - Seleção de entradas do ADC0808.........68

TABELA 8: Erros de conversão do AD .70

TABELA 9: Linhas de comando do programa, com comentários .80

TABELA 10: Programa Principal.......82;83 


\section{Resumo}

OLIVEIRA,G. C. D. (2008) Uma Contribuição para Circuitos Eletrônicos de Medidores de Radiações Ultravioleta para Lentes. Dissertação (Mestrado) - Escola de Engenharia de São Carlos, Universidade de São Paulo, São Carlos, 2008.

O propósito deste trabalho foi o desenvolvimento de um sistema para medir a transmissão das radiações no intervalo $290 \mathrm{~nm}-380 \mathrm{~nm}$, em lentes oftálmicas.

O protótipo é um dispositivo opto-eletrônico, composto por uma fonte de ultravioleta; dois sensores de radiação - UVA e UVB (fotodiodos); um circuito eletrônico para a realização das medidas e um mostrador para fornecer o resultado.

Quando o sistema é ligado, a fonte emite a radiação ultravioleta, e os dois sensores captam os respectivos sinais, no intervalo de UVA e UVB e armazenam estes dados. Ao se colocar uma lente para ser testada, os sensores recebem novamente 0 sinal e dividem pelo sinal armazenado, fornecendo assim, a porcentagem de luz Ultravioleta transmitida pela lente.

Os sinais provenientes dos fotodiodos são amplificados de modo que transformam uma baixa corrente em tensão (na faixa de milivolts), que por sua vez é amplificada para um fundo de escala com tensão máxima igual a 5VCC.

O sinal obtido na saída dos amplificadores é enviado para um conversor analógico digital (A/D); o sinal digital é enviado para um microcontrolador AT89S52, que foi programado para ler dados do conversor $A / D$, ler teclas e proporcionar o laudo escrito em um display.

Polarizadores calibradores e lentes de óculos foram testados no sistema desenvolvido e as medidas comparadas com o espectro de transmissão em um espectrofotômetro Cary 17 - VARIAN. O fator de correlação entre os dois sistemas foi de 0,82 .

O circuito digital apresenta uma imprecisão menor do $1 \%$ nas medidas. Isto tem a implicação direta no fator de correlação entre este protótipo e o espectrofotômetro.

As flutuações da lâmpada também contribuem para a imprecisão, uma vez que a repetibilidade do sistema é de 90\%, em 20 medidas de uma mesma lente. 
Sendo assim, este protótipo é capaz de medir a proteção ultravioleta em lentes de óculos, com uma precisão de $2 \%$. Modificações do sistema serão implementadas no futuro, para que medidas com precisão de 0,5\% sejam atendidas, em protótipo para uso clínico.

Palavras-chave: UVA, UVB, óculos de sol, lente oftálmicas 


\section{Abstract}

The purpose of this work is the development of a system for measuring the transmission of radiation at $290 \mathrm{~nm}-380 \mathrm{~nm}$ range of ophthalmic spectacles. The prototype is an optoelectronic device, assembled by ultraviolet radiation source; two ultraviolet sensors UVA and UVB - (photodiodes); an electronic circuit and a display, as a user interface, for providing the reports.

As the illumination system is turned on, the sensors receive their respective voltage signals, at the UVA and UVB range, and store the data. As a spectacle is placed for testing, the sensors collect the data from the signal and divide them by the previous data stored, providing the percentage of ultraviolet radiation transmitted by the spectacles.

The electronic signals delivered by the photodiodes are amplified in order to convert a low intensity current into voltage (order of milivolts), which is then amplified into a 5 Vcc scale.

The output voltage of the amplifiers is sent to na $A / D$ converter; the digital signal is sent to a microcontroller AT89S52, which is then programmed for reading the data of the converter; reading the keyboard and providing the report on a display.

Calibrating polarizers and spectacles have been tested in the developed system and the data have been compared to the transmission spectrum of a spectrophotometer Cary 17 - VARIAN. The correlation factor was 0.82 .

The electronic digital circuit presents an error lesser than $1 \%$. This has a straight relation on the correlation factor between the prototype and the spectrophotometer.

Output fluctuations of the light source add extra inaccuracy on the system, since the repetitivity of the measurements is $90 \%$, for 20 measurements of the same spectacle.

Hence, the prototype is capable of measuring the ultraviolet protection of spectacles, with a $2 \%$ precision. Modifications on the system should be implemented in a near future, in order to provide $0.5 \%$ accuracy, and then be released for clinical use.

Keywords: UVA, UVB, spectacles, sunglasses 


\section{INTRODUÇÃO}

Para uma melhor saúde ocular, recomenda-se a utilização de óculos com proteção a raios ultravioletas [Atchison, A 2000]. Com o amplo uso popular de óculos escuros e a incerteza quanto à proteção oferecida, há a necessidade de verificação da proteção destes óculos. Este teste deveria ser oferecido em locais de fácil acesso à população como lojas, farmácias, hospitais, laboratórios, etc. O objetivo desta pesquisa é desenvolver um protótipo simples e economicamente acessível para viabilizar este procedimento.

A pesquisa foi iniciada com o estudo dos raios UV e os danos oculares causados [Sliney, D. H 2001], ressaltando que a proteção deve ser total para UVA (315-400nm) e UVB (290-315nm) [Harm, W 1980].

\section{O Olho Humano}

O olho humano pode ser dividido em seis funções físicas fundamentais: a refração, cujos elementos responsáveis são a córnea, o cristalino e os humores aquoso e vítreo; a auto-focalização, feita pelo cristalino e pelos músculos ciliares; o controle da luminosidade interna feito pela íris e pupila; a detecção, feita pela retina (pelos cones e bastonetes); a transmissão da informação ao cérebro, feita pelo nervo e as vias ópticas; e a refrigeração da retina feita pela coróide." Os elementos essenciais do olho, considerado como um sistema ótico, são mostrados na Figura 1.

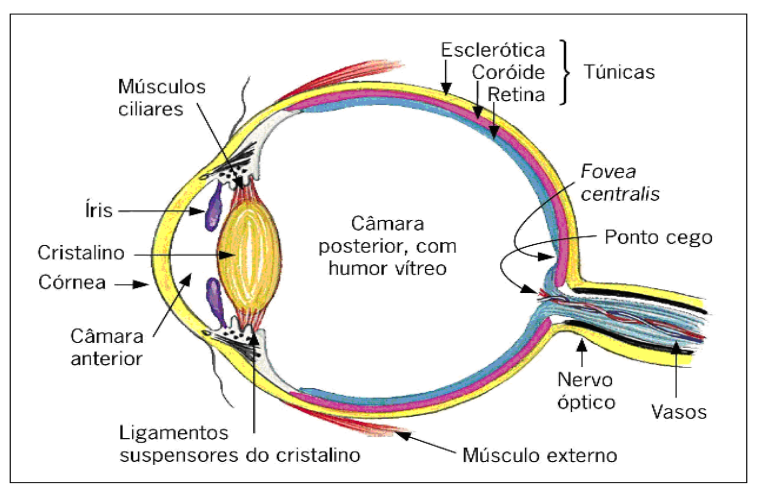

Figura 1 - 0 olho humano. Disponível em < http://www.vision.ime.usp.br/ ronaldo/mac0417-03/aula_02.html> acessado em 07/05/2009 


\section{A Radiação Ultra-Violeta}

Assim como na luz visível, a radiação ultravioleta (RUV) é um tipo de radiação óptica com menores comprimentos de onda e fótons com mais energia (partículas de radiação) do que a porção visível. A maioria das fontes luminosas emite pelo menos uma pequena quantidade de RUV. A radiação ultravioleta está presente na luz do sol e também é emitida por um grande número de fontes ultravioleta, que são utilizadas na indústria, ciência e medicina. Algumas vezes, em ambientes pouco iluminados, fontes muito intensas de ultravioleta podem ser vistas. Porém normalmente a RUV é invisível e pode ser detectada por materiais fluorescentes quando iluminados com a RUV.

Da mesma maneira que a luz pode ser dividida em cores que podem ser vistas em um arco-íris, a RUV é subdividida e suas componentes são denominadas UVA, UVB e UVC. Estas regiões estão distribuídas no espectro como mostra a Figura 2.

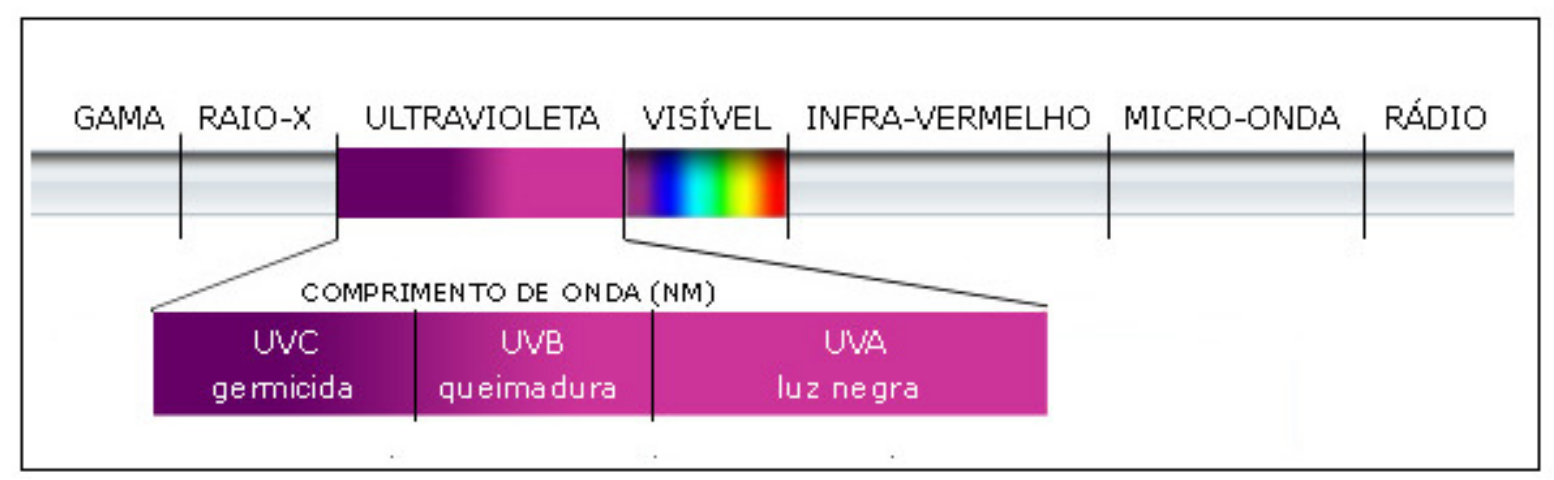

Figura 2 - 0 espectro de radiação. Disponível em <http://www.tratamentodear.com.br/Tratamento-de-arUltravioleta.htm> acessado em 14 maio 2009

Comprimentos de onda da luz e de RUV são geralmente medidos em nanômetros $\left(\mathrm{nm}=10^{-9} \mathrm{~m}\right)$.

As regiões de radiação ultravioleta subdividem-se em:

- UVC: $100-290 \mathrm{~nm}$

- UVB: $290-315 \mathrm{~nm}$

- UVA: $315-380 \mathrm{~nm}$

O UVC na luz solar é absorvido pela atmosfera e não chega até a superfície terrestre. Somente está disponível em fontes artificiais, como lâmpadas germicidas, 
que emitem grande parte de sua energia em apenas um comprimento de onda (254nm), sendo assim bastante eficiente para matar bactérias e vírus em uma superfície ou no ar.

UVB é a radiação ultravioleta mais maléfica para o olho e para a pele. Quase toda sua energia (que é uma componente da luz solar) é absorvida pela atmosfera e produz queimaduras e outros efeitos biológicos. O UVA, que tem o maior comprimento de onda dentro da faixa de RUV, é normalmente encontrado na maioria de fontes luminosas e também é a RUV mais intensa que chega à Terra. Embora o UVA possa penetrar mais profundamente no tecido, o dano provocado não é tão grande como o UVB, pois a energia individual dos fótons são menores do que UVB ou UVC.

Desconsiderando alguma outra fonte de irradiação em conjunto, podemos estimar o espectro da irradiação solar como na Figura 3.

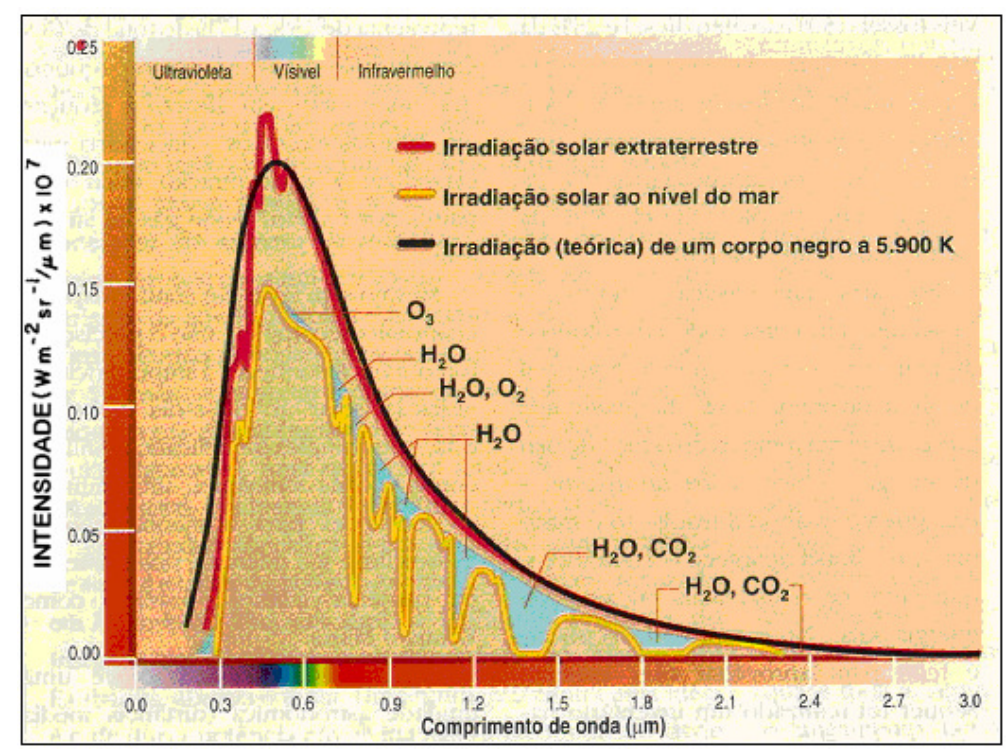

Figura 3 - 0 espectro de irradiação solar. Disponível em <http://www.cptec.inpe.br/satelite/metsat/pesquisa/radsat/radsol.htm> acessado em 04/05/2009

A irradiação teórica do sol é descrita pela curva de cor preta, enquanto que a medida se aproxima ao nível do mar é descrita pela curva de cor amarela.

Através da figura pode-se notar a 'Irradiância Espectral' da região ultravioleta, em comparação à luz visível e infravermelha.

O fato de a camada de ozônio que protege o planeta estar diminuindo, aumenta a irradiação de raios ultravioletas na Terra, pelo Sol. Este fato, junto à notória Irradiância Espectral dos raios UV e sua toxidade ressaltam a importância e preocupação com o controle desta radiação. 
Os efeitos biológicos da radiação ultravioleta são os seguintes [Sliney, D.H 1995]:

- A faixa UVC tem na maioria dos casos um efeito germicida, normalmente não ocasionando sérios danos aos tecidos humanos. Além disso, boa parte da radiação solar UVC é filtrada pela camada de ozônio. Os raios UVC são utilizados comercialmente, por exemplo, para higienização de reservatórios de água e piscinas.

- Os principais efeitos biológicos são causados pelas faixas UVA e UVB da seguinte forma: A energia dos fótons incidentes causa a excitação eletrônica das moléculas atingidas, causando uma reação fotoquímica. Esta reação causa danos à estrutura do DNA e proteínas do tecido atingido.

- A exposição prolongada aos raios UVA e UVB podem causar queimaduras e câncer na pele. Os danos oculares serão explicados a seguir.

\section{As radiações UVA, UVB e UVC}

Em 1801 o físico alemão J.W. Ritter [Beeson, S; Mayer J. W.; 2008 ] realizou uma experiência envolvendo a luz decomposta por um prisma em um pedaço de papel molhado em cloreto de prata. O cloreto de prata escurece quando exposto a luz, como uma chapa fotográfica.

Quando Ritter examinou o pedaço de papel, verificou que ele tinha escurecido num local que estava além da última cor decomposta, o violeta, mostrando que ali havia algum tipo de radiação incidindo. Ritter chamou as radiações que incidiam naquele local de "ultravioleta" (do latim ultra = além), isto é, luz além do violeta. A radiação ultravioleta (UV) é a radiação eletromagnética ou os raios ultravioletas com um comprimento de onda menor que a da luz visível e maior que a dos raios $\mathrm{X}$, de $380 \mathrm{~nm}$ a $1 \mathrm{~nm}$.

A radiação ultravioleta contém fótons com energia mais alta que a luz visível. As propriedades básicas dos raios ultravioletas são as mesmas da luz comum, como: propagação em linha reta com velocidade de $300.000 \mathrm{~km} / \mathrm{s}$ no vácuo e possibilidade de atravessar certos materiais como, por exemplo, o quartzo. A radiação ultravioleta não é totalmente transmitida pelo vidro comum, mas pode atravessar facilmente o quartzo. 
Os raios ultravioletas têm algumas propriedades diferentes da luz visível. Uma das propriedades interessantes é a que torna os raios ultravioletas capazes de excitar determinados materiais, obrigando-os a emitir radiação de menor freqüência. Tem-se, então, uma fluorescência. Incidindo em certos materiais, a radiação ultravioleta consegue deslocar elétrons dos átomos, os quais saltam para níveis superiores de energia, isto é, para órbitas mais afastadas do núcleo. Quando os elétrons voltam para o estado fundamental eles não o fazem num único salto, mas em dois saltos que correspondem a emissões de radiações de menor energia. O resultado é que uma destas energias, ou mesmo as duas, podem corresponder à luz visível. Assim, fazendo incidir um feixe de raios ultravioleta num material deste, ele converterá a radiação ultravioleta em luz visível, brilhando no escuro. Um bom exemplo de material com esta propriedade é o alvejante óptico, utilizado para clarear folhas de papel sulfite. A luz ultravioleta, por sua elevada energia, pode também estimular reações químicas ou agir como catalisador, pois a energia atuará diretamente sobre as moléculas das substâncias que devem reagir. No caso dos seres vivos, a energia elevada desta radiação pode causar a destruição de moléculas orgânicas vitais.

Muitas fontes emitem radiação ultravioleta. O ultravioleta está presente na luz solar e também é emitido por um grande número de fontes usadas na ciência, indústria e medicina. Em algumas instâncias, em um local com baixa luz ambiente uma luz intensa do ultravioleta-próxima ("black light") pode ser vista, mas normalmente a luz ultravioleta é invisível. A luz ultravioleta (UV) é separada em três regiões do espectro: UVA, UVB e UVC . Estas regiões estão distribuídas no espectro como mostra a Figura 4. Quanto menor o comprimento de onda, maior atividade biológica resultante da exposição. 


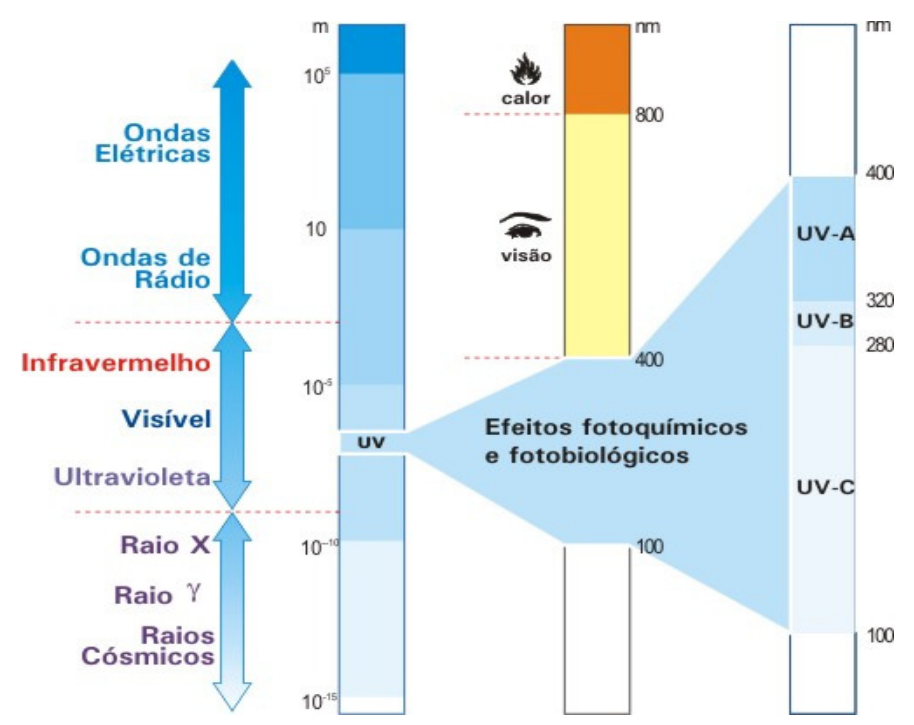

Figura 4: Espectro de radiação eletromagnética .

A radiação UVA é importante para sintetizar a vitamina $D$ no organismo.

A faixa UVB é fortemente absorvida pelo ozônio estratosférico. É prejudicial à saúde humana.

A faixa UVC tem, na maioria dos casos, um efeito germicida, normalmente não ocasionando sérios danos aos tecidos humanos. Além disso, boa parte da radiação solar UVC é filtrada pela camada de ozônio.

Os raios UVC são utilizados comercialmente, por exemplo, para higienização de reservatórios de água e piscinas.

Os principais efeitos biológicos são causados pelas faixas UVA e UVB da seguinte forma: A energia dos fótons incidentes causa a excitação eletrônica das moléculas atingidas, causando uma reação fotoquímica. Esta reação causa danos à estrutura do DNA e proteínas do tecido atingido.

A exposição prolongada aos raios UVA e UVB pode causar envelhecimento precoce queimaduras, câncer na pele e problemas de visão. 


\section{Danos oculares e proteção [Sliney, D. H 2001]}

Do mesmo modo que a radiação ultravioleta pode causar danos à pele humana, ela também pode ocasionar ou intensificar problemas e doenças nos olhos. De um modo geral, a exposição excessiva a qualquer tipo de radiação pode levar a algum tipo prejuízo à saúde dos olhos.

A Tabela 1 apresenta, de acordo com o espectro de radiação, um resumo sobre esses possíveis problemas.

Na tabela 1 o espectro está dividido em: UVC (<280nm), UVB (280-320nm), UVA (320-400nm). Quanto menor o comprimento de onda da radiação, maior o dano causado à estrutura ocular. Por esta razão, as radiações UV são mais nocivas do que a luz nos comprimentos de onda visível e infravermelha.

Outro fator que diferencia os danos causados pela radiação UV é que sua percepção não é imediata. Enquanto a radiação infravermelha se manifesta na forma de calor que pode ser sentido, o UV não provoca nenhuma reação que desperte algum dos sentidos do ser humano.

Da mesma forma que a pele humana, os olhos podem ser mais ou menos sensíveis às radiações. De acordo com a cor, cuidados, idade e condições de saúde do indivíduo, essa sensibilidade tende a ser maior ou menor.

Os tecidos que compõem o globo ocular possuem uma transparência média em relação à luz, e essa transparência é dependente do comprimento de onda. A córnea absorve radiação de comprimento de onda de 300nm (UVB) e tem potencial a sofrer lesões por radiação de $220 \mathrm{~nm}$ a $310 \mathrm{~nm}$, tendo como conseqüência a ceratite.

Tabela 1 - Efeitos da radiação solar sobre o olho humano (adaptado de Vergaz, 2002)

\begin{tabular}{|c|l|l|l|}
\hline Espectro & \multicolumn{1}{|c|}{ Tecido afetado } & Local de absorção & \multicolumn{1}{c|}{ Tipo de dano } \\
\hline UVC / UVB & Córnea & Epitélio & $\begin{array}{l}\text { Fotoquímico: fotoqueratite e } \\
\text { opacidades na córnea }\end{array}$ \\
\hline UVB / UVA & Cristalino & Núcleo & Fotoquímico: Catarata \\
\hline
\end{tabular}


A ceratite é uma doença na qual as células da superfície da córnea morrem. A Figura 5 apresenta a aparência de um olho com ceratite. A causa da ceratite pode ser uma infecção viral, uma infecção bacteriana, olhos secos, a exposição à luz ultravioleta (luz solar, lâmpadas de bronzeamento ou arcos de solda), uma irritação decorrente do uso prolongado de lentes de contato ou do uso de colírios ou uma alergia a esses produtos. A pessoa com ceratite apresenta sintomas de fotofobia, lacrimejamento, sensação de corpo estranho e dor ocular. A figura 5 mostra uma foto de uma ceratite infecciosa.

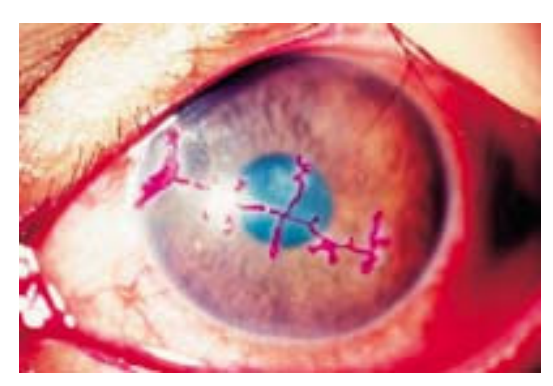

Figura 5: Ceratite infecciosa na forma de dendrito.

A catarata é uma das maiores causas de problemas da visão e cegueira em todo o mundo. Uma das suas principais causas é a radiação UV, especialmente UVB .

O efeito da radiação ultravioleta é cumulativo ao longo dos anos e causa progressivamente uma perda de transparência no cristalino que acaba por afetar a visão. A Figura 6 mostra o aspecto de um olho com catarata. É por isto importante a proteção aos UV em jovens com atividades ao ar livre. As cataratas não aparecem nessa altura, mas o efeito dos UV acumula-se e muitos anos depois, quando aparecem é tarde demais.

Claro que existe cirurgia para isso, mas é melhor se não for necessária. 0 cristalino desempenha um papel importante na proteção às radiações UV e, cirurgias que eliminam esse elemento da estrutura ocular, como a cirurgia de catarata, por exemplo, modificam bruscamente essa condição de proteção e a implantação de lentes protetoras faz-se necessária. Bebês e crianças correm maiores riscos de sofrerem danos oculares devido à maior transparência do cristalino.

Nos adultos esse risco é minimizado, pois o cristalino tende naturalmente a se tornar mais opaco com a idade e, assim, absorver maior quantidade de radiação. Vários estudos têm mostrado que a luz solar aumenta o risco de catarata. 
A radiação ultravioleta danifica o cristalino dificultando a proliferação das células epiteliais alterando as propriedades cinéticas de enzimas no metabolismo aumentando a insolubilidade e diminuindo a solubilidade de proteínas induzindo uma síntese não programada de DNA, atrapalhando o balanço de Sódio Potássio e em conseqüência o balanço de água no cristalino.

Uma das maiores dificuldades nos estudos epidemiológicos tem sido a quantificação da exposição dos raios ultravioletas provenientes do sol. Concomitantemente com a intensidade da luz solar, a dose ocular depende, entre outros fatores, do tempo de exposição.

Sensibilidade ocular versos comprimento de onda e tempo de exposição, que induzem catarata, tem sido estudada experimentalmente em animais. Estudos do limiar da dose de radiação ultravioleta em seu comprimento mais tóxico, que se situa na faixa dos $300 \mathrm{~nm}$, é de $1,5 \mathrm{~kJ} / \mathrm{m}^{2}$ para transiente e $5 \mathrm{~kJ} / \mathrm{m}^{2}$ para o dano permanente do cristalino.

Dedução feita com base nos dados obtidos, com estudos em animais, aplicadas a seres humanos é sempre questionável. Por outro lado é a única opção para o desenvolvimento de uma base empírica e segura de dados sobre a exposição à radiação ultravioleta.

Com base em tais dados, medidas de segurança podem ser tomadas [Sliney D.H; 1986; URBACH, F;1969].

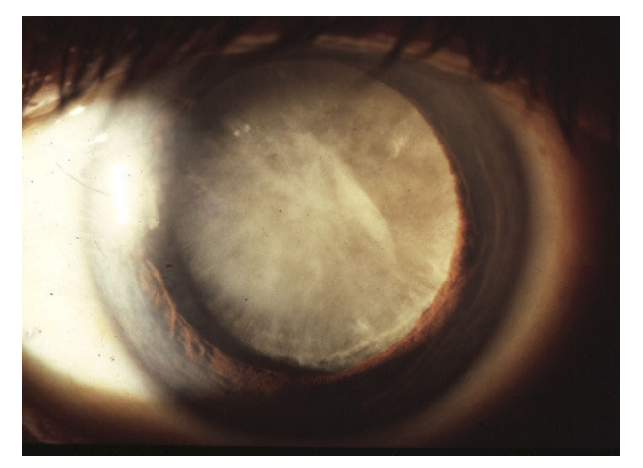

Figura 6: Aspecto de um olho com catarata.

Os danos causados ao olho podem ser divididos em dois tipos distintos de acordo com a forma de exposição: curtas exposições a intensas quantidades de radiação e longas exposições a baixas intensidades de radiação. No primeiro caso o elemento que mais sofre é a córnea, as manifestações são agudas e surgem após um 
período de latência; no outro caso, mais comum nos ambientes de trabalho, o cristalino e a retina são os mais atingidos.

Em ambos os casos a manifestação pode se tornar um processo crônico, mesmo que seja decorrente de um processo agudo. Ainda que não haja uma determinação exata da susceptibilidade do olho à radiação, é certo que doses elevadas produzem fotoconjuntivite (inflamação da conjuntiva) e fotoceratite (inflamação da córnea).

Porém, exposições prolongadas, mesmo a baixas intensidades, podem também produzir cataratas, pterígio ou alguns tipos de carcinomas, que podem ser irreversíveis ou exigir uma intervenção cirúrgica.

Como a R-UV não é necessária para a visão, não existem motivos para evitar métodos de atenuar a intensidade desse tipo de radiação e, conseqüentemente, proteger os olhos.

A radiação solar chega aos olhos de forma direta e indireta (radiação difusa). A Figura 7 ilustra como os raios de ultravioleta atingem a estrutura ocular. Essa segunda forma é ainda mais importante no caso da R-UV, devido ao intenso espalhamento nessa região do espectro.

Os filtros empregados na construção de óculos deveriam ser opacos aos comprimentos de onda menores que 400nm (UV) e maiores que 700nm - infravermelho (IV) [Vergaz, 2002]. Porém, a maioria das lentes permite a passagem de certa quantidade de radiação nesses comprimentos de onda.

Os cristais transparentes reduzem a exposição em cerca de 16\%, enquanto outros orgânicos retêm cerca de 0,2\%. As lentes adequadas devem estar livres de imperfeições, eliminar mais de 99\% da R-UV e entre 75 e 90\% da radiação visível, evitando incômodo ocular e reflexões excessivas.

De acordo com recomendações internacionais [EEC, 1989], os fabricantes devem indicar claramente o grau de proteção de cada lente. Os graus de proteção variam numa escala de 0 a 4.

A radiação da faixa UVA e parte da radiação UVB não são absorvidas pela córnea, portanto é transmitida e causam lesões ao cristalino e à retina [Harm, W 1980].

De um modo geral, o uso de lentes protetoras, que filtram os raios ultravioletas, auxilia a prevenção de várias doenças oculares, como catarata, degeneração macular relacionada à idade e pterígio. 
Pesquisas médicas não comprovaram diretamente, mas através de dados estatísticos demonstram que as doenças citadas acima estão relacionadas à exposição ocular indevida aos raios ultravioletas.

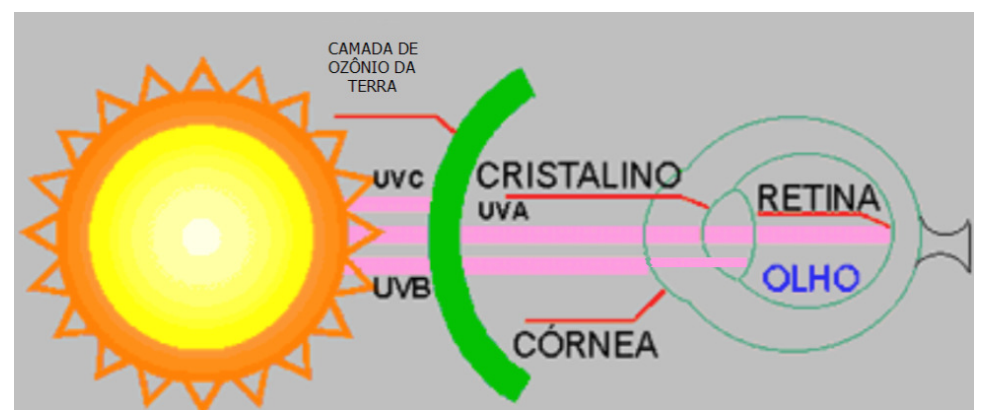

Figura 7 - Os raios UV e a estrutura ocular. Retirada do "website" <http://www.interfacehs.sp.senac.br/br/secao_interfacehs.asp?ed=10\&cod_artigo=173\&pag=3> acessado em 04 de maio de 2009 e modificada.

O olho humano possui mecanismos de defesa naturais que são inibidos pela escuridão proporcionada pelas lentes. A pupila, que automaticamente se fecharia diante da luminosidade, mantém-se dilatada quando se faz uso de lentes escuras. A reação natural do ser humano de fechar os olhos é comprometida pela utilização dos óculos de sol. Portanto, se as lentes não protegem, os raios ultravioletas passam e afetam a retina mais severamente do que se não fosse usado nenhum tipo de lente.

As lentes de uso comum, de vidro ou acrílico, já filtram a radiação na faixa UVC e parte da radiação UVB [Hetch, E. 1990]. Mas, para proteção efetiva, as lentes devem ser tratadas quimicamente para filtrar toda a radiação ultravioleta. Lentes tratadas para este propósito geralmente recebem um selo de garantia de proteção UV do próprio fabricante. A Figura 8 ilustra a absorção e proteção aos raios UV.

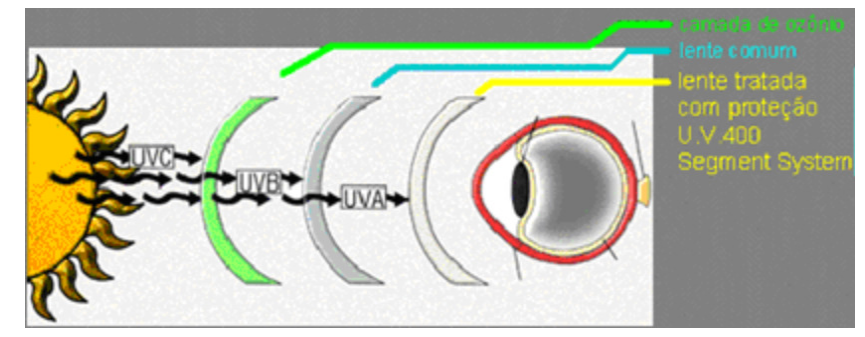

Figura 8 - 0 funcionamento da absorção e proteção aos raios UV. Disponível em <http://www.interfacehs.sp.senac.br/br/secao_interfacehs.asp?ed=10\&cod_artigo=173\&pag=3> acessado em 04 de maio de 2009 


\section{Riscos da Radiação Ultravioleta [NBR15111, 2004]}

As equações de caráter analítico da luz solar ultravioleta [Green, A. E. S. ; et al, 1980] adotadas para cálculo da potência de irradiação da córnea [Hoover, H. L., et al, 1986] mostram que, nas regiões temperadas, o mais importante fator de influência na exposição na exposição dos olhos é a variação sazonal da potência de irradiação solar, seguida da refletividade no solo e , por fim, a hora em relação ao meio dia solar córnea [Hoover, H. L., et al, 1985]. A radiação difusa do céu diminui quando a altitude aumenta [Piazena, H., 1993; Blumenthaler, M. et al, 1985], e a incidência de radiação da córnea permanece quase constante. As bases dos limites do fator de transmitância adotados são, portanto, as doses de exposição calculadas e consideradas sob o ponto de vista biológico, bem como os limites correspondentes do fator de transmissão no ultravioleta para óculos solares que manteriam estas doses abaixo de um limite de segurança reconhecido para experiências excepcionais (superiores ao plausível realizável) da exposição diária [Davis, J. K.; 1990]. São incorporadas margens de segurança, em aditamento às implícitas nas experiências de exposições excepcionais. As especificações de limites espectrais do fator de transmissão (em vez de limites médios ou considerados) aumenta igualmente de modo considerável as margens de segurança [Hoover, H. L., 1987].

Existem várias normas internacionais que descrevem a proteção necessária dos filtros para óculos de sol. São elas: Americana: AMERICAN STANDARD (ANSI Z80.32001); Européia: EUROPEAN STANDARD (EN 1836:2005); Australiana/Neozelandesa: AUSTRALIAN/NEW ZEALAND STANDARD (AS/NZS 1067:2003). A norma brasileira é a NBR15111, que é baseada em normas Européias.

\section{Norma Brasileira NBR15111}

A norma brasileira [NBR15111; 2004], estabelece as características físicas (mecânicas, ópticas etc.) para óculos de sol e filtros de proteção solar com potência 
nominal nula, que sejam lentes para óculos corretivos, mas previstos para uso geral na proteção contra radiações solares e também para uso social e doméstico, inclusive no trânsito.

A norma brasileira é baseada nas normas Européias de proteção de radiação UV em óculos, que afirmam que há necessidade de se proteger as lentes com filtros quanto às radiações de 290nm - 380nm. Existem 5 categorias de óculos, apresentadas na Tabela 2.

TABELA 2: Valores de Transmitâncias para Filtros Solares de Uso em Óculos - dados retirados na norma NBR15111.

\begin{tabular}{|c|c|c|c|c|c|c|}
\hline \multirow[t]{2}{*}{$\begin{array}{l}\text { Catego } \\
\text { ria }\end{array}$} & \multirow[t]{2}{*}{ Perfil da Lente } & \multirow{2}{*}{$\begin{array}{l}\text { Exigência } \\
\text { de } \\
\text { Redução } \\
\text { Solar }\end{array}$} & \multirow{2}{*}{$\begin{array}{c}\text { Região Visível } \\
\text { do Espectro } \\
\text { de } \\
\text { Transmitância } \\
\text { Luminosa }\left(\mathrm{T}_{\mathrm{V}}\right)\end{array}$} & \multicolumn{3}{|c|}{$\begin{array}{c}\text { Transmitância Permitida no } \\
\text { UV }\end{array}$} \\
\hline & & & & $\begin{array}{c}280 \mathrm{~nm} \\
-315 \mathrm{~nm} \\
\text { UVB }\end{array}$ & $\begin{array}{c}\text { 315nm } \\
-350 \mathrm{~nm} \\
\text { UVA }\end{array}$ & $\begin{array}{c}350 \mathrm{~nm} \\
-380 \mathrm{~nm} \\
\text { UVA }\end{array}$ \\
\hline 0 & $\begin{array}{l}\text { Lentes } \\
\text { ornamentais: não } \\
\text { são óculos de sol }\end{array}$ & Pouca & $80 \%-100 \%$ & \multirow{5}{*}{$0,1 \mathrm{~T}_{\mathrm{v}}$} & \multirow{3}{*}{$T_{v}$} & \multirow{3}{*}{$T_{v}$} \\
\hline 1 & $\begin{array}{l}\text { Lentes } \\
\text { ornamentais: não } \\
\text { são óculos de sol }\end{array}$ & Baixa & $43 \%-80 \%$ & & & \\
\hline 2 & Óculos de sol & Média & $18 \%-43 \%$ & & & \\
\hline 3 & Óculos de sol & Alta & $8 \%-18 \%$ & & \multirow{2}{*}{$0,5 \mathrm{~T}_{\mathrm{v}}$} & \multirow{2}{*}{$0,5 \mathrm{~T}_{\mathrm{v}}$} \\
\hline 4 & Óculos de sol & Muito alta & $3 \%-8 \%$ & & & \\
\hline
\end{tabular}

Para transitar ou dirigir, os filtros devem pertencer às categorias $0,1,2$, ou 3 .

\section{Projeto de Lei}

No Brasil existe um projeto de lei (no. 5.534 de 2005), que torna obrigatória a proteção contra ultravioleta nos óculos.

Desta forma, o presente trabalho é de fundamental importância para a contribuição da informação à população sobre esta proteção. 


\section{MATERIAIS E MÉTOdOS}

\section{Testes em Medidores de UV Existentes}

Previamente ao desenvolvimento de nosso sistema, alguns medidores existentes no mercado foram estudados e testados.

Existem três equipamentos comerciais, que medem a quantidade de raios ultravioletas que passam pela lente dos óculos, mas a maioria deles não cobre o espectro de $280 \mathrm{~nm}$ - $400 \mathrm{~nm}$, ou apresentam escalas errôneas de leitura, ou falta informação, etc.

Foi adquirido o medidor comercial para testes. As Figuras 9 e 10 contêm, respectivamente, a fotografia do equipamento e seu diagrama em blocos.

O aparelho comercial utiliza como fonte de luz ultravioleta a lâmpada: - BLB (Black Bulb) TL 4W/08 F4 T5/BLB. O espectro desta lâmpada foi adquirido no espectrofotômetro Cary 17 - Varian e está apresentado na Figura 11.

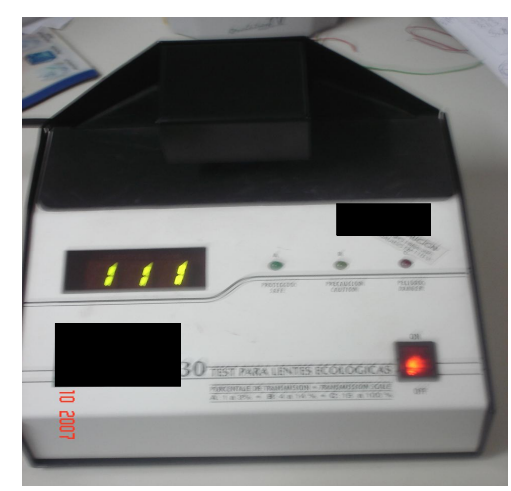

Figura 9: Medidor comercial.

O sensor de UV do equipamento comercial é um fotodiodo de Silício, que tem uma alta sensibilidade no vermelho e infra-vermelho. $O$ circuito eletrônico é composto de amplificador, conversor analógico/digital e microcontrolador. A interface com 0 usuário possui 3 displays de 7 segmentos e três $L E D s$. 


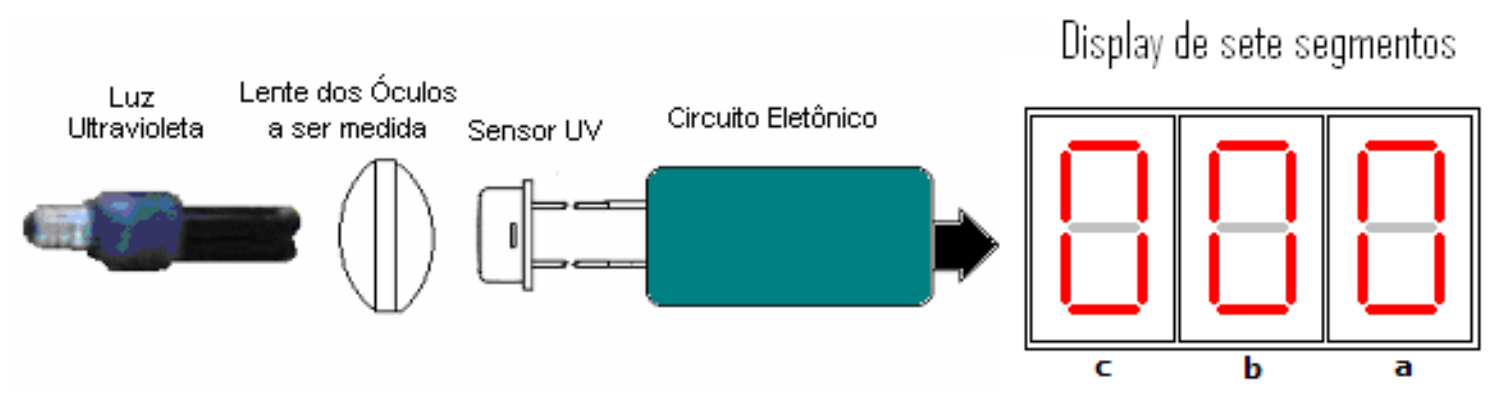

Figura 10: Diagrama em blocos do medidor U.V.

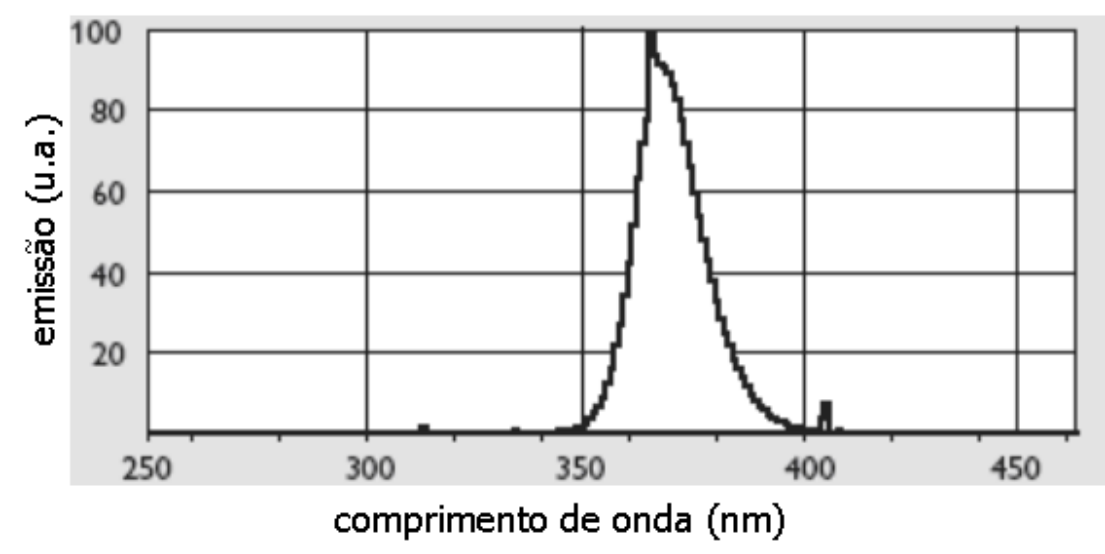

Figura 11: Espectro da lâmpada TL 4W/08 F4 T5/BLB.

Ao se ligar o medidor, são apresentados os dígitos 999 no display; em seguida 888, e assim sucessivamente, até chegar a 000. O tempo da contagem regressiva é o tempo necessário para aquecer a lâmpada, isto é, o tempo supostamente necessário para se obter uma potência de emissão constante. No caso, 10s.

Quando o medidor termina a contagem são apresentados três traços no display. Neste momento é necessário pressionar um botão (vermelho, que fica na lateral do medidor, como apresentado na Figura 12) para o ajuste do de fundo de escala do medidor. 


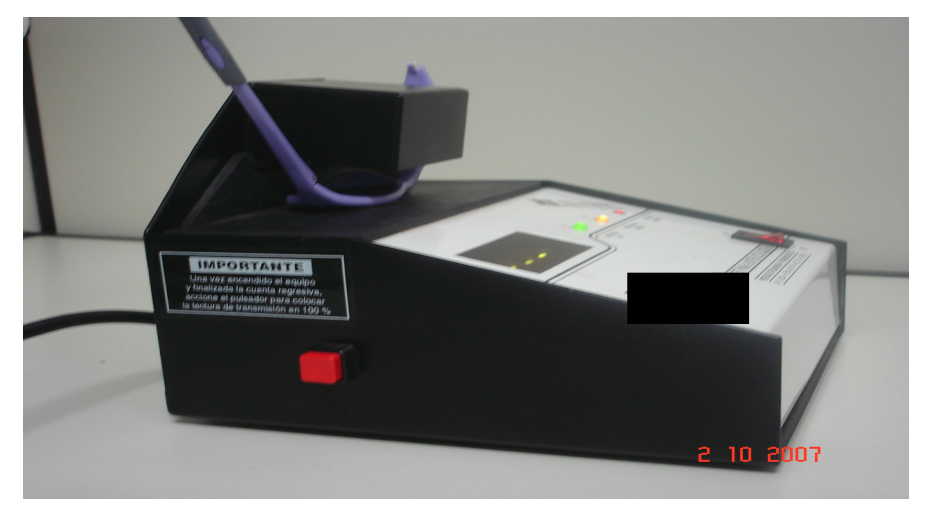

Figura 12: Botão para ajuste do fundo de escala.

Quando o botão da lateral é pressionado, o display passa a exibir $100 \%$. Neste momento é inserida a lente dos óculos a ser medida e o display passa a exibir 0 percentual de luz transmitido pela lente.

Quando a transmitância está na faixa de 1 a $3 \%$ um LED verde acende indicando protegido, quando a transmitância está na faixa de 4 a 14\% um LED amarelo acende indicando precaução e quando a transmitância está na faixa de $15 \mathrm{a}$ $100 \%$ um $L E D$ vermelho acende indicando perigo.

Para aferir o medidor de ultravioleta foram utilizados polarizadores.

A seguir uma breve explanação sobre polarizadores. 


\section{Polarizadores [Hetch, E.;1990]}

A luz é considerada, pela teoria eletromagnética, como ondas transversais, sendo as direções de vibração dos campos elétricos e magnéticos perpendiculares à direção de propagação. As fontes comuns de luz emitem energia radiante que se propaga em todas as direções, abrangendo todo o espectro de freqüência de vibrações e comprimentos de onda. Porém quando a luz comum atravessa um filtro polarizador, apenas os componentes dos trens de onda cujos vetores elétricos vibram paralelamente à direção de orientação do filtro serão transmitidos, neste caso os outros vetores elétricos serão absorvidos pelo filtro.

Por definição, pode-se dizer que a luz polarizada possui vetores elétricos que vibram em planos de orientação paralela - vice Figura 13.

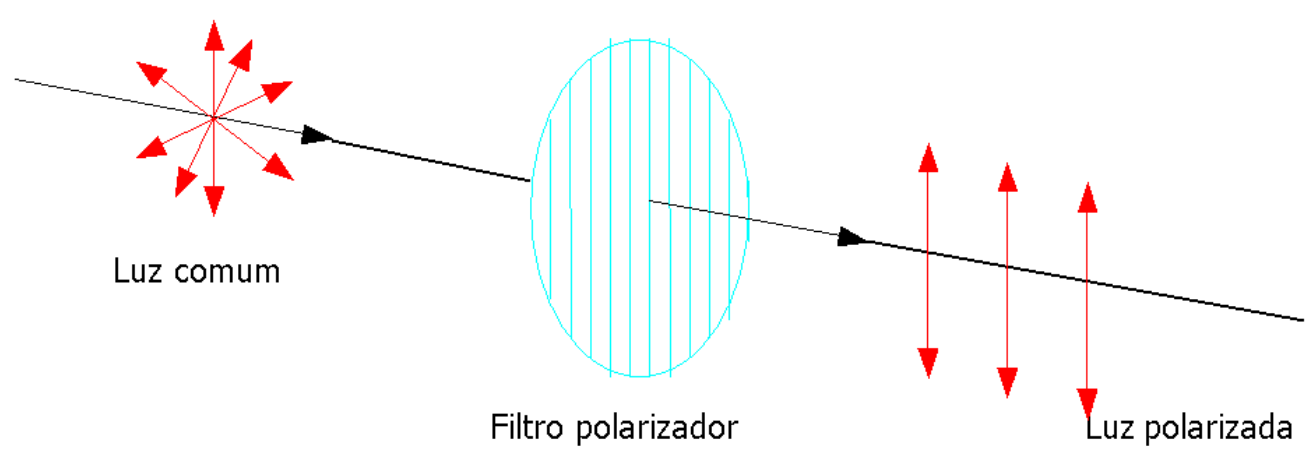

Figura 13: Representação da polarização da luz.

Os filtros polarizadores ou Polaróides basicamente são placas de plástico flexível, nas quais durante o processo de fabricação são inseridas moléculas de cadeia longa. A direção de polarização é estabelecida estirando-a de modo que as moléculas se alinhem todas paralelamente entre si. Desta forma quando um trem de ondas de uma luz comum incidir sobre o filtro, será transmitido apenas o componente paralelo a orientação do filtro. Caso sejam utilizados dois filtros polarizadores no trajeto luminoso, será de extrema importância conhecer-se o ângulo formado entre as orientações de propagação de ambos, pois dele dependerá a intensidade luminosa transmitida, este fenômeno é equacionado pela Lei de Malus [Hetch, E.; 1990]:

$$
I=I_{m} \cos ^{2}(\theta)
$$


Onde: $\mathbf{I}=$ intensidade transmitida

$I_{m}=$ intensidade máxima de transmissão

$\boldsymbol{\theta}=$ ângulo entre as direções de propagação dos filtros

Segundo a Lei de Malus, a intensidade luminosa transmitida será máxima quando o ângulo $\theta$ assumir os valores $0^{\circ}$ e $180^{\circ}$ (orientação paralela) e mínima quando o ângulo $\boldsymbol{\theta}$ assumir os valores $90^{\circ}$ e $270^{\circ}$ (orientações ortogonais) - vide Figura 14.

Luz comum

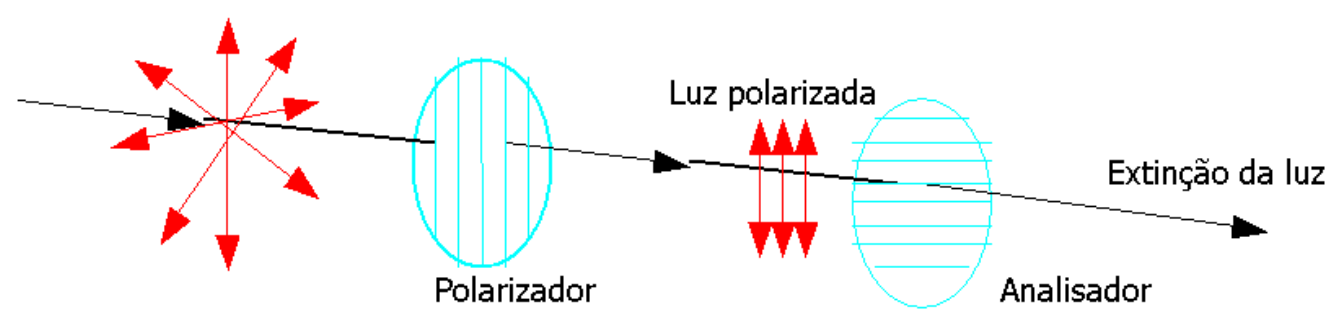

Figura 14: Análise da luz, com dois filtros polarizadores dispostos ortogonalmente.

Para calcular o índice de correlação entre o medidor comercial e o espectrofotômetro, foram utilizados dois polarizadores circulares sobrepostos, com graduação de $1^{0}$ num total de $180^{\circ}$.

Os polarizadores foram posicionados entre a lâmpada (emissor de UV) e o fotodiodo (receptor de UV). Os polarizadores foram sobrepostos de modo que um ficou fixo e o outro era rotacionado, como ilustra a Figura 15.

Foram efetuadas medidas de transmitância a cada $1^{0}$, de $0^{0}-180^{\circ} \mathrm{e}$ comparadas com as do espectrofotômetro.

O fator de correlação foi de 0,75 .

Isto mostra a falta precisão do equipamento testado. 


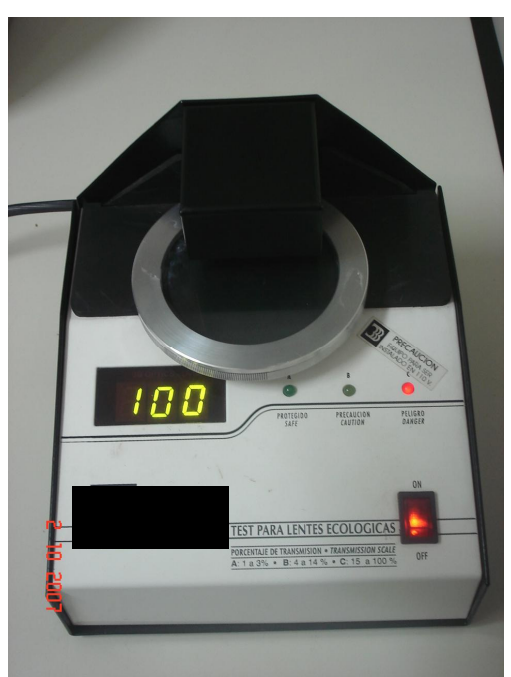

(a)

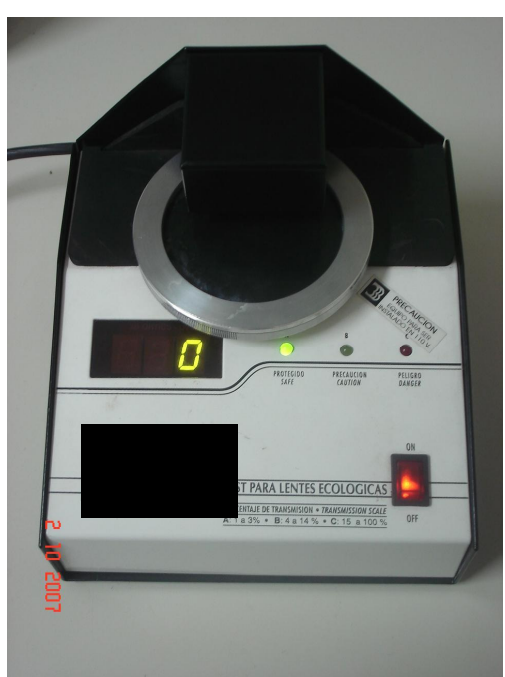

(b)

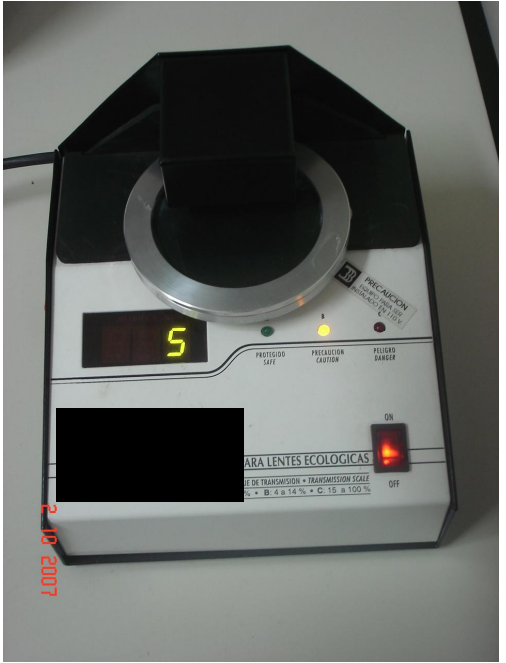

(c)

Figura 15: Medidas efetuadas com polarizadores: (a) paralelos; (b) ortogonais; (c) a $45^{\circ}$.

\section{Protótipo Desenvolvido}

Com esta imprecisão para estes medidores atuais, o propósito foi desenvolver um primeiro protótipo, com a função de medir, com precisão suficiente, as lentes de óculos de sol, quanto a sua proteção às radiações UVA e UVB.

Este trabalho, para seu desenvolvimento, baseou-se na norma brasileira NBR15111 -, com o cunho voltado para filtros de óculos de sol, categoria 4.

Assim, todo desenvolvimento eletrônico foi no sentido de proporcionar precisões e intervalos de medidas que satisfaçam esta norma.

De uma forma sucinta, o protótipo desenvolvido neste trabalho consiste em irradiar a face anterior da lente teste na região do ultravioleta $(290 \mathrm{~nm}-380 \mathrm{~nm})$ e detectar a quantidade de radiação UV relativa transmitida através dela, com um sensor localizado após a face posterior da lente. A quantidade de radiação relativa é dada procedendo-se do seguinte modo: quanto acionado o botão para teste de lente, o sensor capta o sinal em volts (100 valores em 1s e faz uma média) que chega até ele, sem a lente, armazena este dado e quando colocada a lente, o sensor realiza novamente a medida e compara os dois resultados fornecendo o laudo em porcentagem de luz UV transmitida pela lente testada.

O sistema está descrito a seguir. 


\section{O Sistema Desenvolvido do Protótipo}

O protótipo para medidas dos raios UVA $(290 \mathrm{~nm}-315 \mathrm{~nm})$ e UVB $(315 \mathrm{~nm}-$ $400 \mathrm{~nm}$ ) consiste em uma fonte de luz UV, uma lente que será medida, um sensor de UV, um microcontrolador para o processamento eletrônico e um display. O objetivo é medir a proteção de uma lente que deve ser inserida no sistema pelo usuário. A representação da posição onde a lente será inserida pode ser vista na Figura 16.

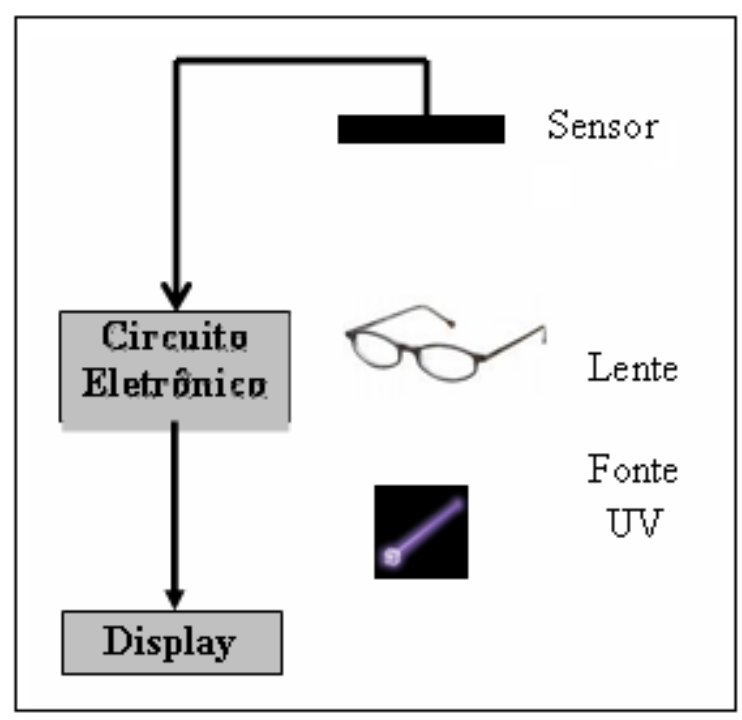

Figura 16 - Diagrama em blocos do sistema.

Esta dever ser posicionada entre a lâmpada e o sensor para evitar que a radiação de UV atinja o sensor quando a lente tiver $100 \%$ de proteção contra radiação ultravioleta. Assim, quando uma lente com $50 \%$ de proteção for inserida no sistema, incidirá no sensor apenas $50 \%$ de radiação UV em relação a um sistema sem lente alguma.

\section{A Fonte de Radiação UV}

Para a escolha da fonte de radiação, foram pesquisadas lâmpadas e leds que possam emitir luz nas faixas UVA e UVB (290 a 380nm).

Os LEDs disponíveis para consumo no Brasil possuem a faixa espectral de radiação muito curta, não cobrindo toda a faixa de radiação pretendida. Existem também LEDs importados, de alto custo (ordem de U\$250 cada) e que são vendidos apenas em grandes quantidades. 
Algumas lâmpadas que também emitem radiação UV: mercúrio (alta/média/baixa pressão) e Mercúrio com aditivos (Xe, Cd, Fe,..), Deutério e lâmpadas fluorescentes.

As lâmpadas de Mercúrio e Deutério têm o seu espectro composto por "raias", que são picos em alguns pontos do espectro da luz, o que não é interessante.

Algumas lâmpadas fluorescentes tipo BLB (Black Bulb), conhecidas no mercado como "Luz Negra", têm espectro que cobre a faixa desejada e são de baixo custo. Foram adquiridos algumas lâmpadas tipo BLB e LEDs UV nacionais para serem testados.

A Figura 17 mostra as lâmpadas adquiridas que foram testadas.

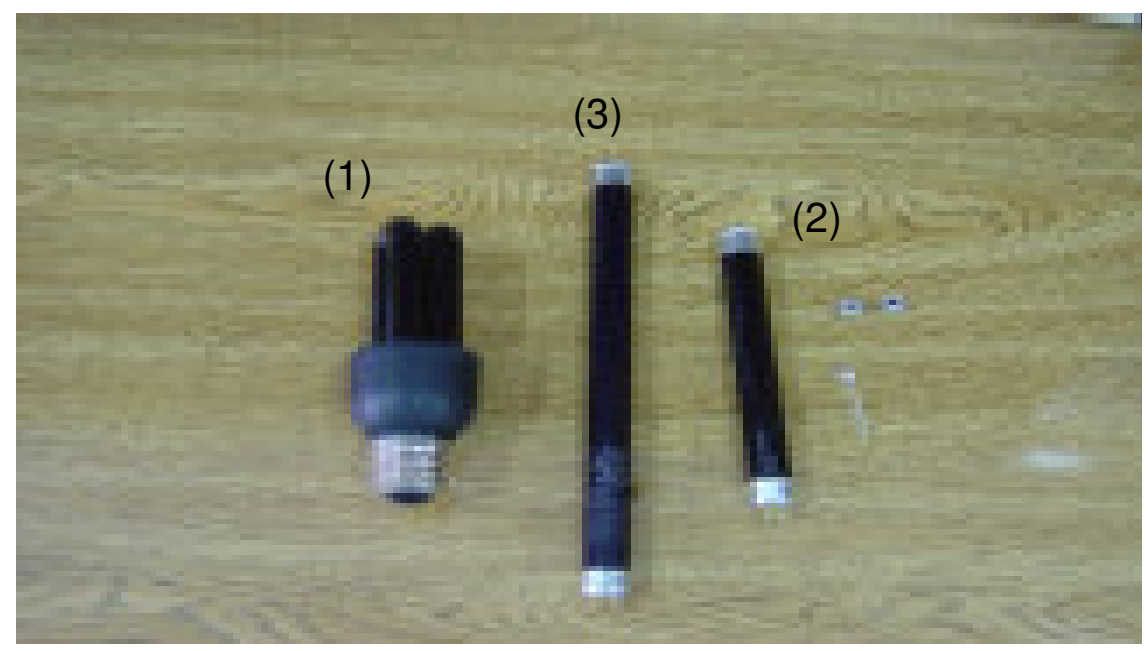

Figura 17: Lâmpadas BLB: 1. Masterkey modelo BLB 2U 9W; 2. Light Express BLB 4W e; 3. Sankyo denki BLB 6W

Os espectros de emissão destas fontes foram medidos num espectrofotômetro Cary 17 da Varian, no Laboratório do Prof. Dr. Lino Misoguti, do IFSC-USP. A Figura 18 apresenta o espectro de cada uma das fontes. 


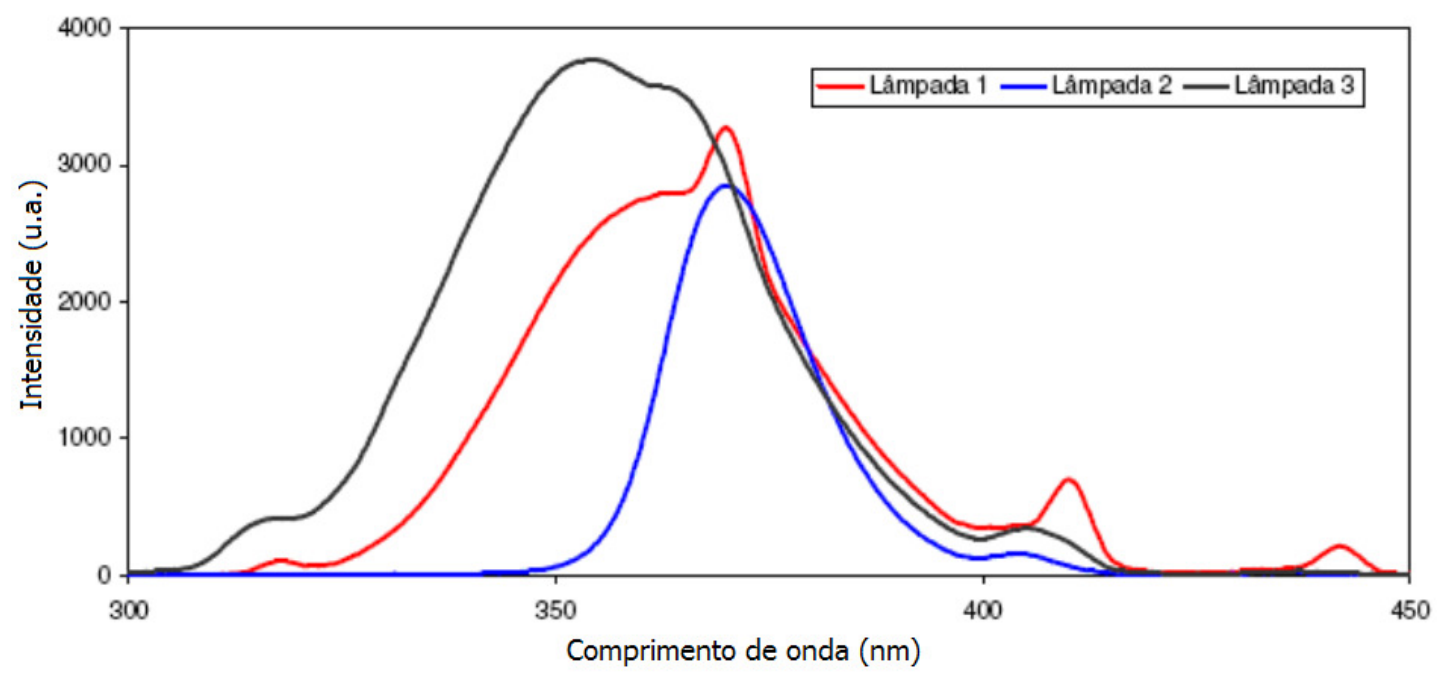

Figura 18 - Espectros de emissão das Lâmpadas BLB: 1. Masterkey modelo BLB 2U 9W; 2. Light Express BLB 4W e; 3. Sankyo denki BLB 6W

No protótipo foi utilizada a lâmpada Sankyo Denki BLB (6W), pois ela é a que cobre a faixa necessária para o projeto. 


\section{Detectores de Radiação UV- A e UV- B}

Como sensor de luz UV, foram pesquisados e utilizados fotodiodos de silício tipo 'PIN'. São comuns no mercado os circuitos integrados OPT-101, que é um fotodiodo acoplado a um amplificador interno.

O OPT-101 é sensível a uma faixa muito grande de radiação, englobando a luz visível, ultravioleta e infravermelho.

Foram escolhidos dois modelos da marca EOC-INC (Eletro Optical Inc.): JEC 0.1A (UVA ) e JEC 0.1B (UVB ), cujos espectros de sensibilidade estão apresentados na Figura 19:

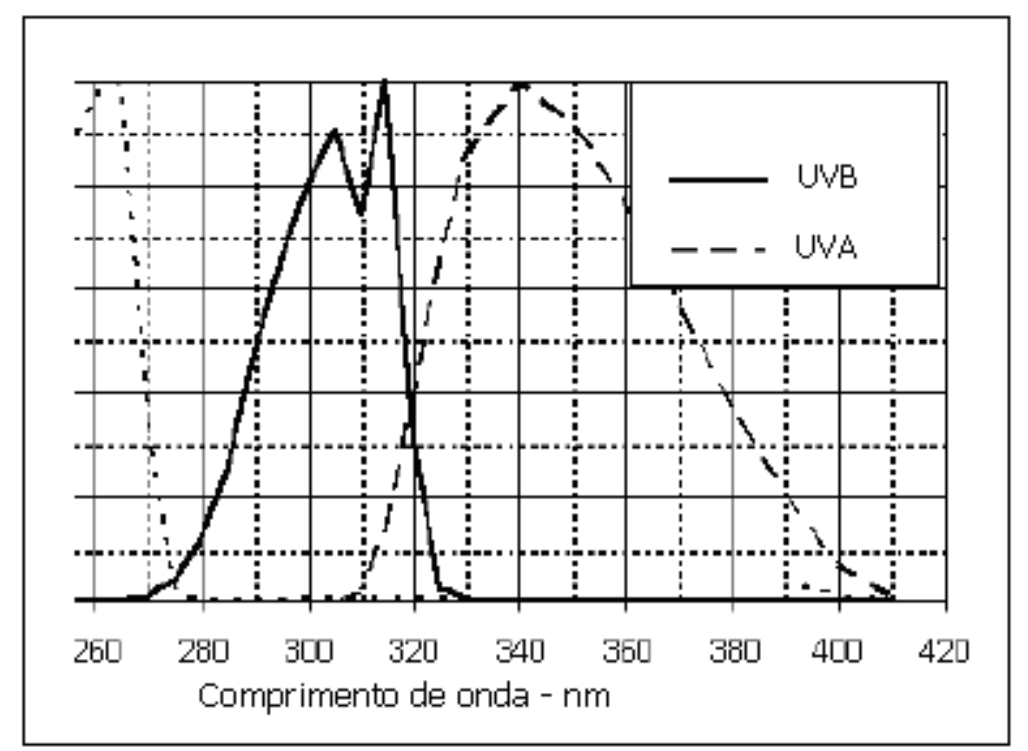

Figura 19 - Espectro de sensibilidade dos dois sensores JEC 0.1A (UVA) e JEC 0.1B (UVB ) - figura retirada do catálogo dos sensores.

\section{O fotodiodo}

O fotodiodo é um diodo de junção construído de forma especial, de modo a possibilitar a utilização da luz como fator determinante no controle da corrente elétrica. É um dispositivo de junção PN semicondutor cuja região de operação é limitada pela região de polarização reversa e caracteriza-se por ser sensível à luz.

Possui uma "janela" ou uma conexão de fibra ótica, responsável por deixar a luz passar e incidir na parte sensível do dispositivo. Também pode ser usado sem a "janela" para detectar raios ultravioleta ou raios-x.

Fotodiodos podem ser usados tanto na polarização reversa quanto na polarização direta. Na polarização direta, a luz que incide sobre o fotodiodo faz a 
corrente transcorrer através do dispositivo, levando-a para o sentido frontal. Isso é conhecido como o efeito fotoelétrico. Diodos geralmente possuem uma altíssima resistência quando a polaridade é revertida. Essa resistência é reduzida quando a luz, em uma apropriada freqüência, brilha na junção. De fato, um diodo de polaridade reversa pode ser usado como um detector, monitorando a corrente que passa por ele.

Circuitos baseados nesse efeito são mais sensíveis à luz que outros baseados no efeito fotovoltaico.

A aplicação de luz à junção resultará em uma transferência de energia das ondas luminosas incidentes (na forma de fótons) para a estrutura atômica, resultando em um aumento do número de portadores minoritários e um aumento do nível da corrente reversa. A corrente negra é a corrente que existirá sem nenhuma iluminação aplicada. A corrente retornará a zero somente se for aplicada uma polarização positiva igual à $\mathrm{V}_{0}$.

Dessa forma, quanto maior a incidência de luz, maior a corrente no fotodiodo polarizado reversamente. Por isso, quando o fotodiodo está trabalhando na região linear de sua curva característica, a corrente reversa tem a mesma forma de onda da amplitude da intensidade luminosa incidente. A corrente inversa e o fluxo luminoso variam quase que linearmente, ou seja, um aumento na intensidade luminosa resultará em um aumento semelhante na corrente inversa. A Figura 20 apresenta as curvas características do fotodiodo.

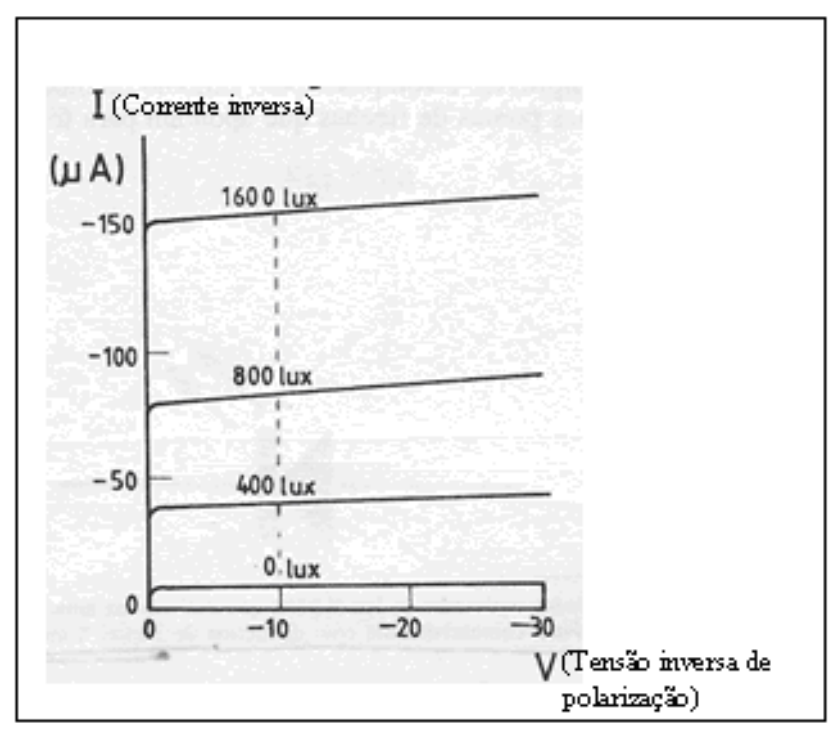

Figura 20: Curva característica do fotodiodo. 
Em resumo, pode-se dizer, então, que a corrente reversa e o fluxo luminoso variam quase que linearmente, ou seja, um aumento na intensidade luminosa resultará em um aumento proporcional na corrente reversa.

Para a montagem do circuito eletrônico era essencial ter a certeza de linearidade dos sensores escolhidos. 


\section{O Sistema Eletrônico}

O objetivo principal do sistema eletrônico é controlar o acionamento das lâmpadas e o conversor analógico digita; fazer a leitura das medidas dos sensores; calibrar o sistema; calcular a porcentagem do sinal analógico recebido pelos sensores; e mostrar em um display alfanumérico a porcentagem de proteção ultravioleta das regiões UVA e UVB.

A interface com o usuário é feita através de um display, 3 botões (UVA, UVB e ESC).

O processo de medição passa pelas seguintes etapas:

1. Ao ligar o aparelho, o usuário recebe o aviso de calibração que é executado automaticamente sem a lente a ser testada;

2. Neste momento, após a estabilização do sinal (da fonte de luz), 100 medidas são realizadas e o dado armazenado num microcontrolador;

3. Após a calibração o usuário deve posicionar a lente no local indicado e escolher o teste de UVA ou UVB para a medição ser aferida.

4. Para cada teste escolhido, o sistema divide o sinal recebido após a inserção da lente, pelo sinal armazenado, apresentando o resultado em porcentagem de luz transmitida;

5. O resultado da proteção da lente é exibido num display e o usuário poderá retornar ao menu anterior para escolher outro tipo de teste.

A Figura 21 apresenta o diagrama em blocos do medidor de ultravioleta.

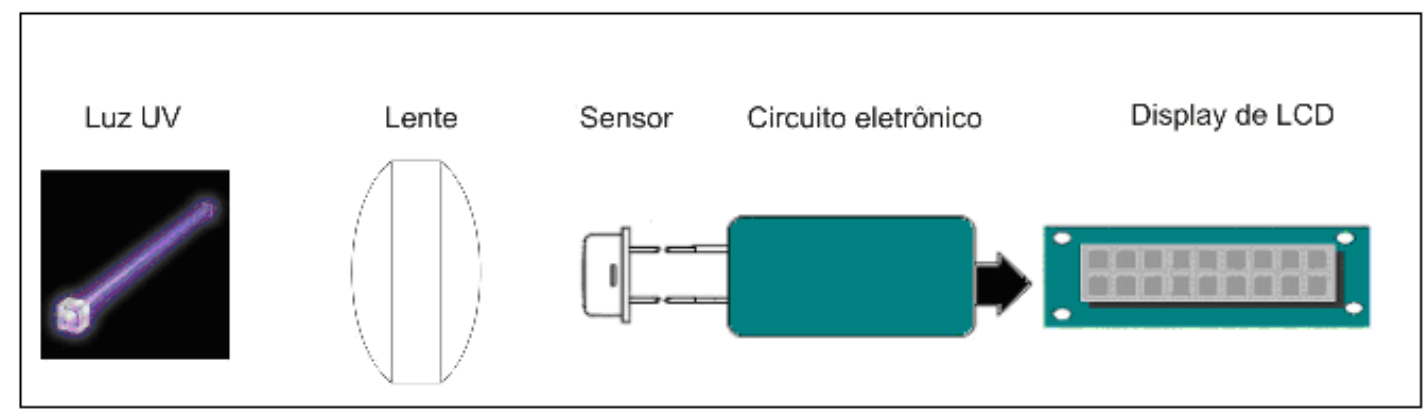

Figura 21: Diagrama em blocos do sistema desenvolvido. 


\section{Hardware do Protótipo}

O hardware pode ser dividido em 5 blocos funcionais:

1. Fonte

2. Microcontrolador

3. Controle das lâmpadas BLB

4. Amplificação e aquisição do sinal

5. Interface com usuário

A Figura 22 mostra o esquema geral de ligações, contendo os componentes utilizados. A função de cada componente será detalhada adiante.

\section{Fonte}

A fonte utiliza um transformador 127 / $15+15 \mathrm{~V} / 1 \mathrm{~A}$, que transforma 127V em 15VAC. A ponte de diodos é para a retificação completa da onda senoidal de entrada. Os circuitos integrados (CI) LM 7805, LM 7812 e LM 7912 são reguladores de tensão e fornecem respectivamente $+5 \mathrm{VCC},+12 \mathrm{VCC}$ e $-12 \mathrm{VCC}$. Estas saídas alimentam todo o circuito. A alimentação simétrica é necessária para alimentar os amplificadores operacionais utilizados no circuito.

O esquema da Figura 23 representa o diagrama de blocos da fonte e a Figura 24 representa o bloco da fonte de alimentação. 


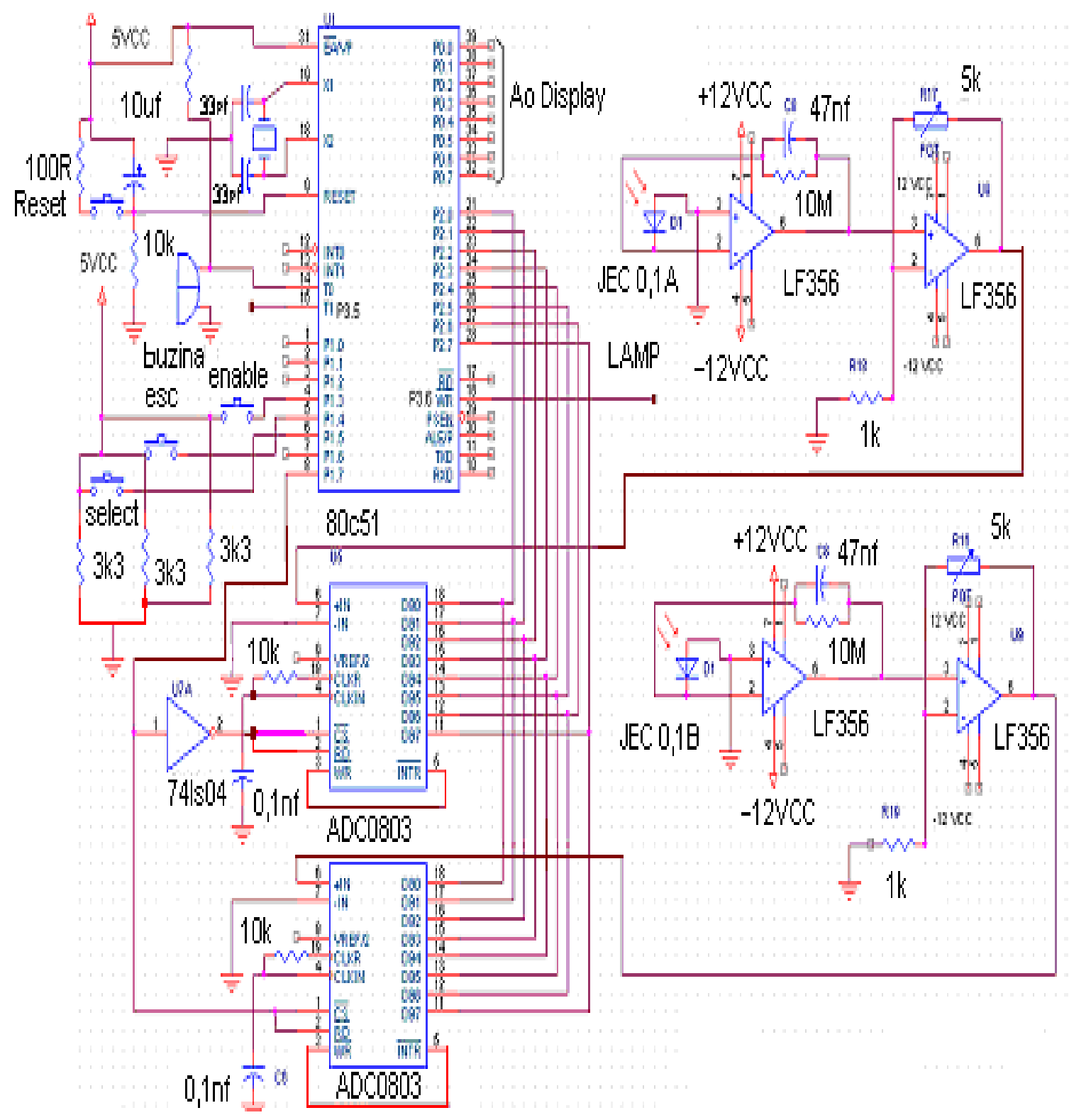

Figura 22: Esquema geral de ligações do medidor.

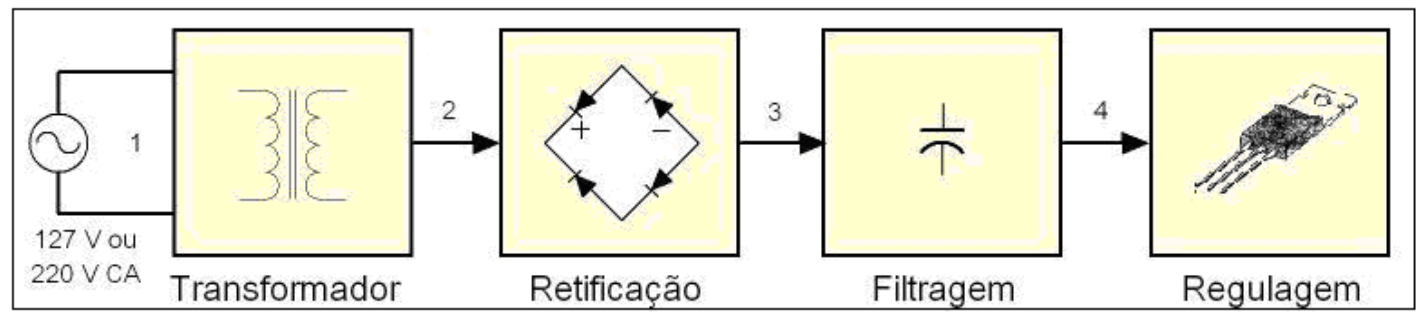

Figura 23: Diagrama de blocos da fonte de alimentação. 


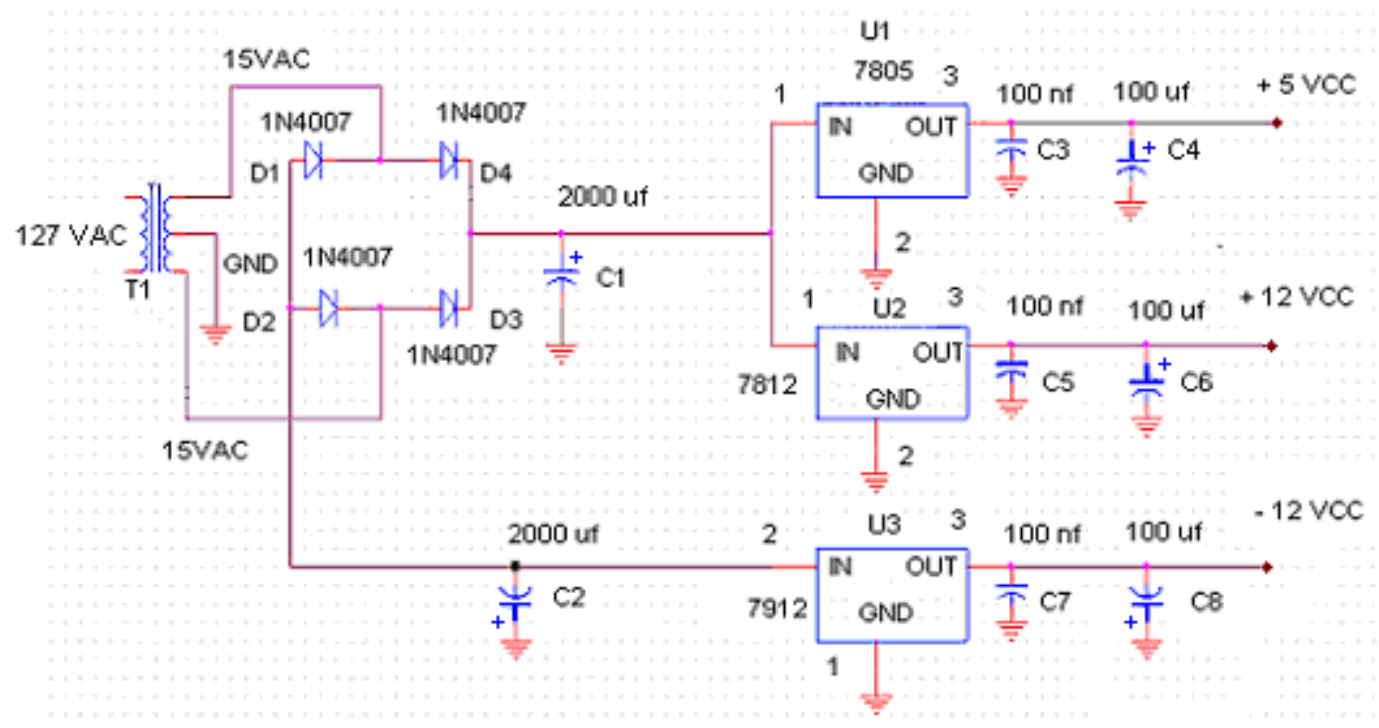

Figura 24: Fonte de alimentação.

A segunda etapa da fonte consiste de uma ponte de diodos. Essa ponte de diodos funciona como um retificador de onda completa. A Figura 25 ilustra as formas de onda de saída um retificador de onda completa produzidas com uma entrada senoidal.

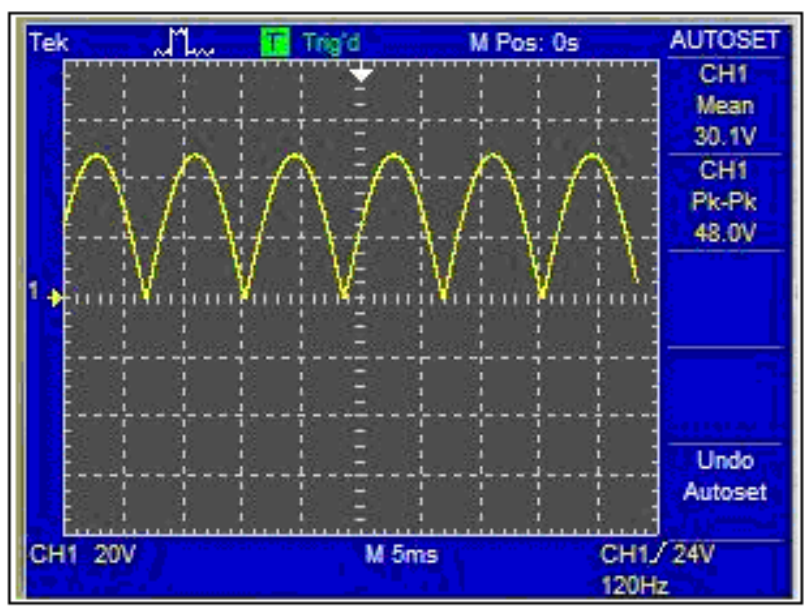

Figura 25: Saída de um retificador de onda completa para uma entrada senoidal - imagem gerada a partir osciloscópio Tektronix TDS 220

A próxima fase consiste de filtros que são feitos por capacitores eletrolíticos que transformam a tensão senoidal retificada em uma tensão contínua com menos ripple, como mostrado na Figura 26. 


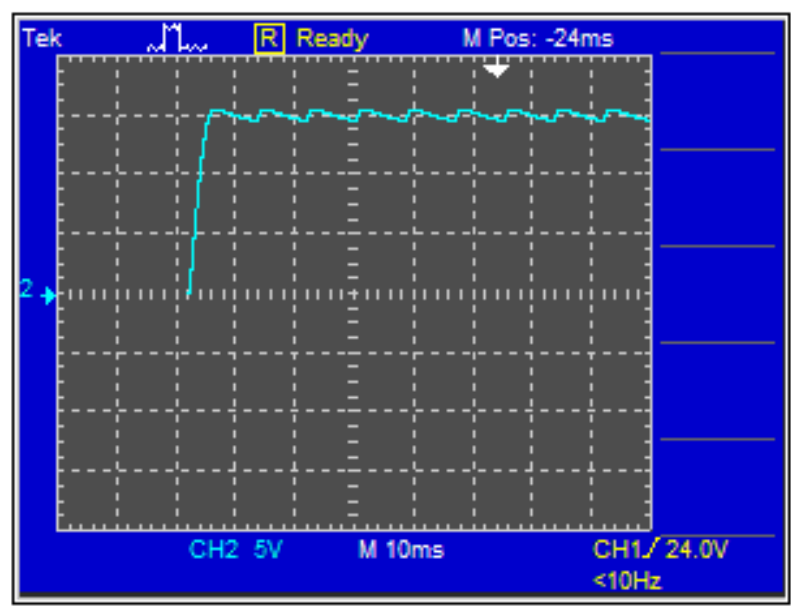

Figura 26 - Saída do retificador após filtragem - - imagem gerada a partir do osciloscópio Tektronix TDS 220

Após passar pelo regulador de tensão o sinal de saída fica com poucas ondulações, como mostrado na Figura 27.

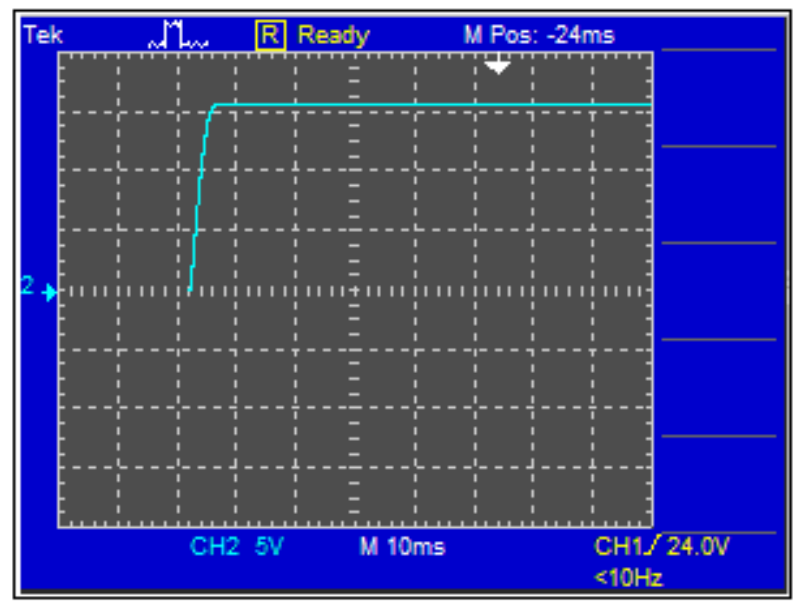

Figura 27: Saída do retificador após o regulador de tensão - - imagem retirada retirada do osciloscópio Tektronix TDS 220 


\section{Microcontrolador}

O microcontrolador utilizado no projeto é o AT89S52 da Atmel. O AT89S52 é um microcontrolador de baixíssimo consumo de potência, CMOS de alto desempenho, com 8 Kbytes de memória flash programável. O dispositivo é fabricado utilizando tecnologia de alta densidade e é compatível com o conjunto de instruções e pinagem do 89C51, de acordo com o datasheet do fabricante. A memória flash on-chip permite programar a memória de programa in-circuit ou por um programador de memória convencional. A Figura 28 contém a pinagem do microcontrolador utilizado no circuito.

O 89552 tem como principais características:

- 8k bytes de memória flash;

- 256 bytes de RAM;

- 32 portas de I/O;

- 3 timers / contadores de 16 bits;

- porta serial full duplex.

\begin{tabular}{|c|c|c|c|}
\hline & & & \\
\hline (T2) P1.0 ᄃ & 1 & 40 & a vcc \\
\hline (T2 EX) P1.1 & 2 & 39 & P0.0 (ADO) \\
\hline P1.2 ᄃ & 3 & 38 & P0.1 (AD1) \\
\hline P1.3 ᄃ & 4 & 37 & $\square$ P0.2 (AD2) \\
\hline P1.4 ᄃ & 5 & 36 & P0.3 (AD3) \\
\hline (MOSI) P1.5 ᄃ & 6 & 35 & P0.4 (AD4) \\
\hline (MISO) P1.6 ᄃ & 7 & 34 & P0.5 (AD5) \\
\hline (SCK) P1.7 ᄃ & 8 & 33 & P P0.6 (AD6) \\
\hline RST ᄃ & 9 & 32 & P0.7 (AD7) \\
\hline (RXD) P3.0 ᄃ & 10 & 31 & EA $\overline{E A P P}$ \\
\hline (TXD) P3.1 ᄃ & 11 & 30 & D ALE/PROG \\
\hline (INT0) P3.2 ᄃ & 12 & 29 & PSEN \\
\hline 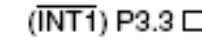 & 13 & 28 & P2.7 (A15) \\
\hline (T0) P3.4 ᄃ & 14 & 27 & P2.6 (A14) \\
\hline (T1) P3.5 ᄃ & 15 & 26 & P2.5 (A13) \\
\hline$(\overline{\mathrm{WR}})$ P3.6 ᄃ & 16 & 25 & P2.4 (A12) \\
\hline$(\overline{\mathrm{RD}})$ P $3.7 \square$ & 17 & 24 & P2.3 (A11) \\
\hline XTAL2 $\square$ & 18 & 23 & P2.2 (A10) \\
\hline XTAL1 & 19 & 22 & P2.1 (A9) \\
\hline GND & 20 & 21 & P2.0 (A8) \\
\hline
\end{tabular}

Figura 28: Descrição da pinagem do 89552. 
As conexões com as portas de $\mathrm{I} / \mathrm{O}$ do microcontrolador foram feitas de modo a deixar a porta apenas como entradas, ou apenas como saídas. Deste modo, as portas P0, P2 e P3 estão configuradas apenas como saídas, enquanto que P1 está configurada apenas como entrada. Existem outros microcontroladores comerciais da família PIC que podem ser utilizados no projeto, porém o utilizado é o mais fácil de ser encontrado comercialmente e é o que apresenta melhor custo benefício em relação aos concorrentes.

As instruções do AT89S52 são cadenciadas por um relógio. O relógio é o elemento que gera e controla os ciclos de trabalho de máquina. Cada ciclo de oscilação será chamado de $\mathrm{P}$ (pulso). A cada dois pulsos $\mathrm{P}$ caracteriza-se um estado $\mathrm{S}$. Uma seqüência de seis estados, S1 a S6 corresponde a um ciclo de máquina. O reset é um pino físico do chip chamado RST, para zerar o microcontrolador. O pino RST deve ficar ao menos dois ciclos de máquina no estado 1,ou seja, high. Na energização do +VCC o capacitor C estará descarregado e assim aplicará um pulso high no pino RST. Em seguida, esse pulso vai para zero, com constante de tempo dada pelo RC. O reset forçado faz o capacitor se descarregar e carregar de novo, aplicando novamente um pulso high no RST. O diagrama da Figura 29 ilustra o circuito de reset adotado no medidor.

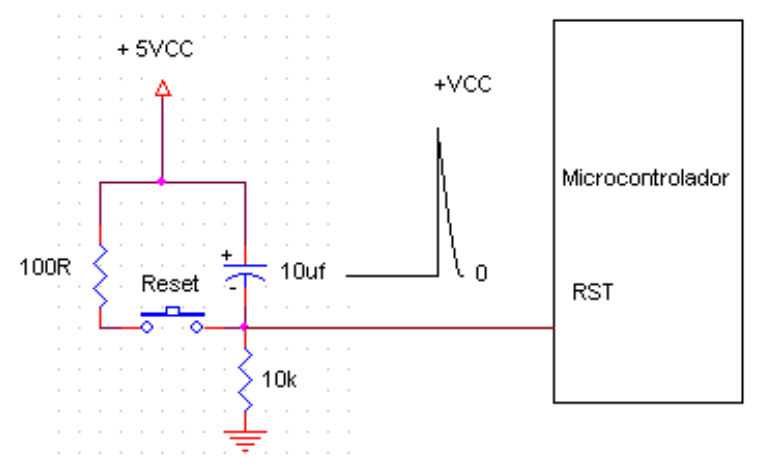

Figura 29: Circuito de reset automático e forçado.

No reset, vários registradores são forçados a estados definidos. O contador do programa, o "PC" é forçado para o início da ROM, isto é, 0000h que é a posição de início do programa.

A porta P0 é de uso geral de oito bits. Ela pode ser usada para fornecer os endereços menos significativos a um latch, através da multiplexação de dados (os mais significativos são fornecidos pela porta P2). Dessa forma, o microcontrolador 
AT89S52 pode trabalhar com a memória externa para multiplexar dados e endereços. Utilizamos o pino ALE, que sinaliza quando está-se transmitindo dados ou endereços.

No projeto do medidor de ultravioleta não foi utilizado o modo multiplexado (memória externa), apenas foi utilizada a memória interna; assim, a porta P0 foi utilizada como duto de dados bidirecional, que foi conectado à via de dados do display $L C D$.

A porta P1 também é uma porta de uso geral, que contém oito bits, onde se pode ler ou escrever nela bit a bit. No projeto, a porta P1.0 foi utilizada como enable do display LCD; a porta P1.1 foi utilizada como Register Select; a porta P1.2 foi ligada ao pino WR do display LCD; as portas $\mathrm{P} 1.3, \mathrm{P} 1.4, \mathrm{P} 1.5$ foram utilizadas, respectivamente, como pinos de entrada para os botões enable, esc e select; e o pino P1.7 foi utilizado para seleção de um dos dois conversores $A / D$,

A porta P2 é de uso geral, se não for utilizada nenhuma memória externa. No projeto do medidor de ultravioleta, a porta P2 está ligada ao dois conversores A/D. Para que não haja conflito de dados, é selecionado um conversor por vez através de seus pinos chip select. Quando o chip select está em nível 1, os pinos de dados do conversor A/D ficam em tri-state. A seleção do conversor A/D é feita pela porta P1.7.

Quando P1.7 está em nível 1, o chip select do conversor A/D número 1, chip U9, que passa por um inversor, está em nível 0. Então, dá-se a troca de dados entre 0 microcontrolador e o conversor $A / D$, número 1. Já o chip select do conversor $A / D 2$, que está ligado diretamente à porta $\mathrm{P} 1.7$, está em nível 1. Em conseqüência, a saída do conversor A/D, número 2, está em tri-state. Quando a porta P1.7 está em 0, dá-se o contrário.

A porta P3 também é um port de uso geral, se não for utilizado para comunicação com os periféricos internos (porta serial TXD, RXD) ou geração de sinais de controle para periféricos externos (RD, WR, PSEN e ALE/P).

No projeto a porta P3.4 foi utilizada para acionar a buzina; a porta P3.5 foi utilizada para acionar o LED; e a porta P3.6 foi utilizada para acionar as lâmpadas ultravioleta. O pino EA é um pino de comando externo, que determina a memória $R O M$ interna ou externa a ser utilizada. No projeto, este pino foi ligado ao nível 1, que implica no uso da memória ROM interna. As portas são constituídas internamente por latches ligados a buffers tri-state e suas saídas são open-colector, o que implica no uso de resistores de pull-up quando da excitação de drivers externos. Como mostra a Figura 30. 


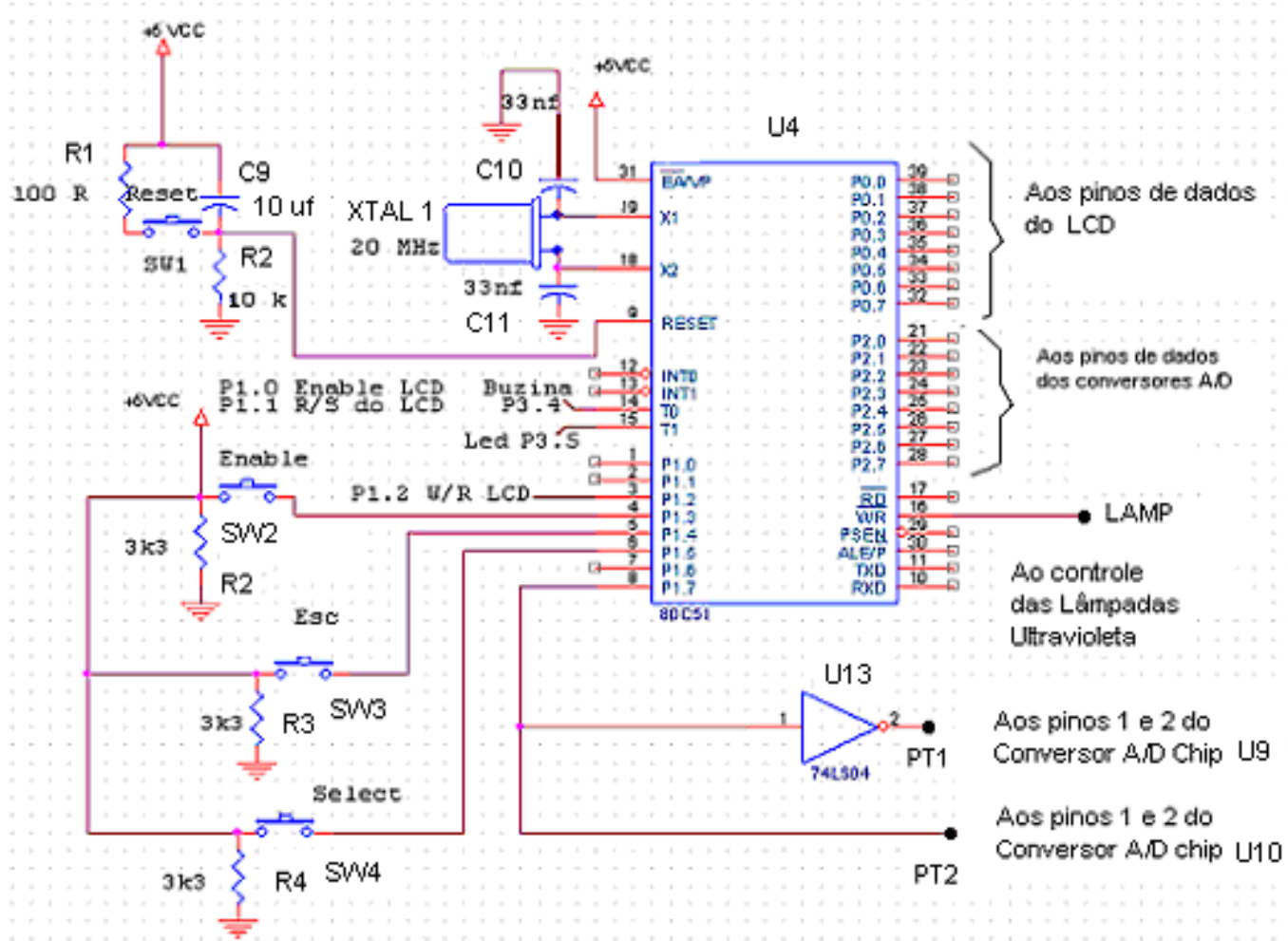

Figura 30: Esquema de interligações do microcontrolador.

A eletrônica do sistema subdivide-se em duas partes: analógica e digital.

\section{Analógica}

\section{Controle da Lâmpada BLB}

O controle da lâmpada BLB é feito por um relé comum (símbolo K1) - Figura 31, que tem 5 terminais.

Inicialmente, os terminais 3 e 5 do relé estão curto-circuitados. Ao aplicar uma tensão de $5 \mathrm{~V}$ nos terminais 1 e 2, o relé mudará a chave e os terminais 3 e 4 estarão conectados.

Para chavear a tensão de 5V no comando do relé, há o transistor Q1. Se o sinal de LAMP estiver em nível 0 , o transistor não conduzirá e o relé estará com $0 \mathrm{~V}$. Se o sinal de LAMP estiver em 1, o relé também estará em 1 com o chaveamento do transistor. O microcontrolador controla, via software, a variável LAMP.

Finalmente, o conector JP2 é ligado em série com um fio de alimentação da lâmpada (de preferência a fase). Deste modo o relé controla se a lâmpada está ligada ou desligada. 


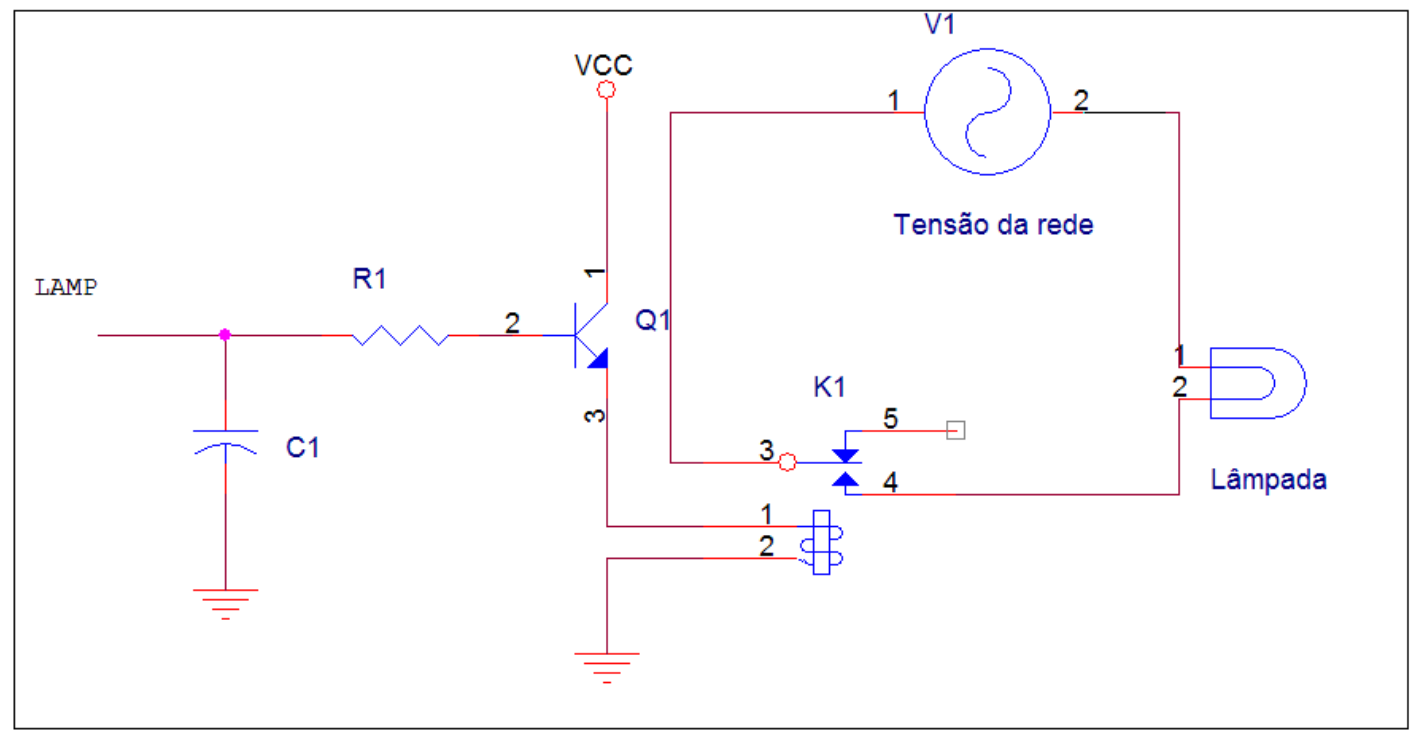

Figura 31 - Esquemático do acionamento da lâmpada BLB.

\section{Amplificação e aquisição do sinal}

Este bloco de amplificação e aquisição do sinal tem como entradas os sinais provenientes dos dois sensores (fotodiodos). Estes sinais entram em conversores corrente/tensão e depois passam por amplificadores. Os amplificadores estão configurados no modo não-inversor e têm ganhos iguais a $(1+R 1 / R 2)$ e $(1+R 3 / R 4)$, respectivamente.

Este ganho deve ser ajustado de acordo com o nível do sinal proveniente do sensor, tal que os amplificadores tenham uma saída máxima de 4 a $8 \mathrm{~V}$ quando 0 sensor está recebendo luz do sistema sem as lentes.

O ajuste da tensão máxima de saída é feito através dos potenciômetros POT1 e POT 2 . A Figura 32 apresenta o esquema dos amplificadores. 


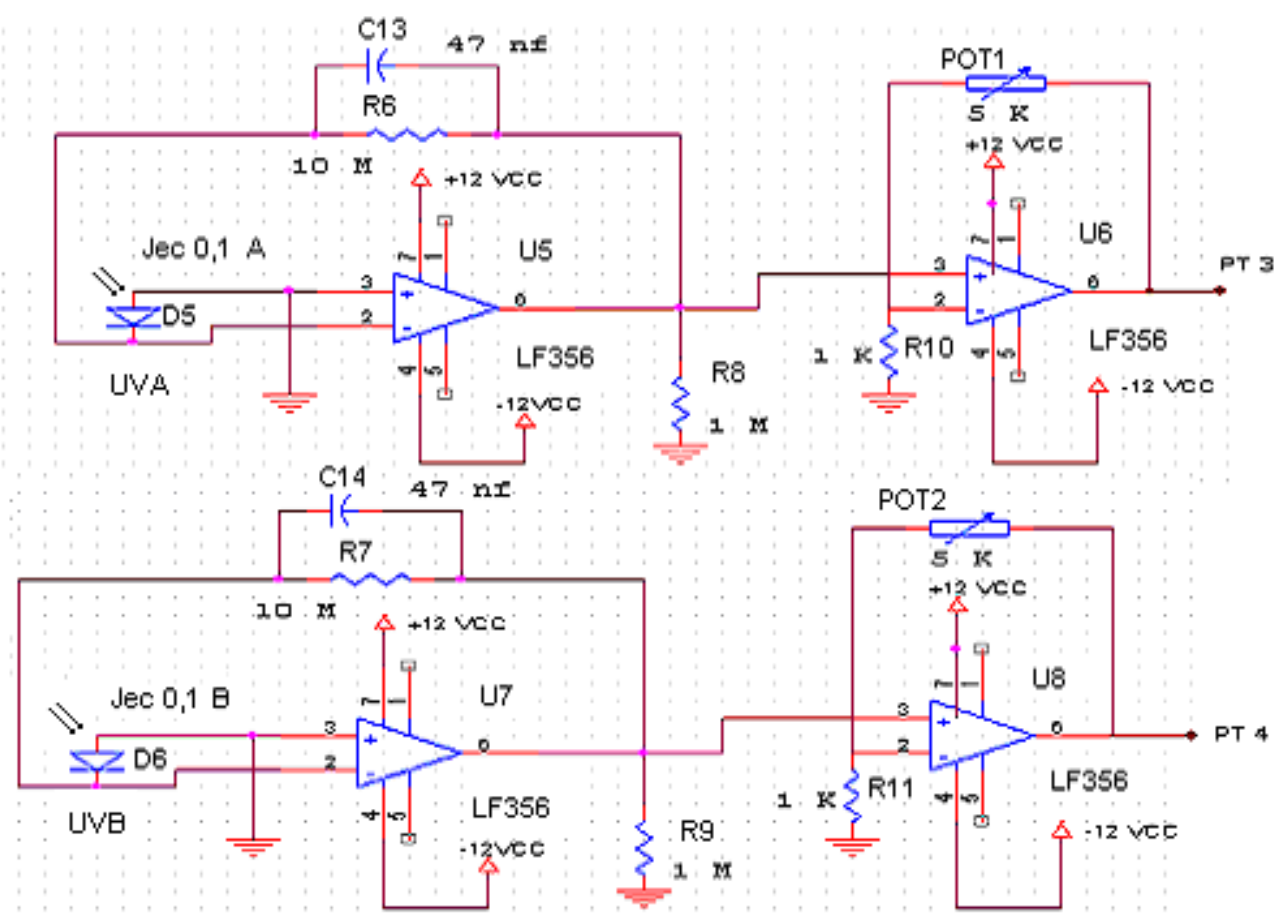

Figura 32: Esquema de interligação entre conversor corrente tensão e amplificador.

Depois de amplificado o sinal é aplicado aos conversores A/D. Para conversor A/D foi utilizado o ADC 0803. O conversor Analógico Digital ADC0803 é um Circuito Integrado capaz de converter uma amostra analógica entre 0 e $5 \mathrm{v}$, em um valor binário de 8 bits. Para sabermos a resolução do conversor temos que saber o valor máximo que a entrada suporta e o tamanho máximo da saída em bits. A equação (2) apresenta o cálculo de resolução para o ADC0803.

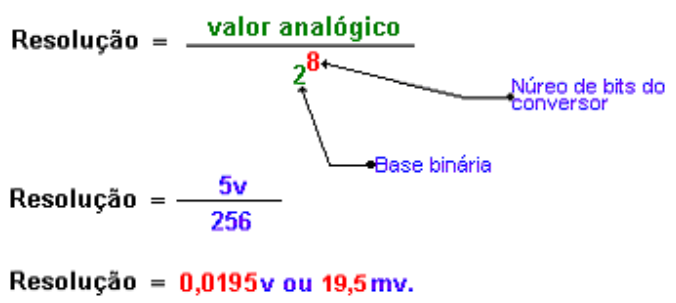

Esse dispositivo trabalha com o princípio de aproximação sucessiva.

Chaves analógicas são fechadas seqüencialmente, pela aproximação lógica, até que, o comparador de auto-zero [VIN(+)-VIN(-)] seja igual a tensão do decodificador. Depois que todos os bits são testados e verificados, os 8 bits binários 
correspondentes a entrada de voltagem é transferido para um latch de saída. A conversão começa com a chegada de um pulso da entrada WR se o CS (chip-select) está em nível baixo.

Na transição de alto para baixo do sinal WR, CS ou SAR é inicializado, o shiftregister é zerado, e a saída INTR (interrupção) é ajustada em nível 1. O A/D irá ficar zerado enquanto CS e WR ficarem em nível 0. A conversão será inicializada no período de 1 à 8 períodos de clock. Depois que a conversão está completa, o pino INTR fará uma transição de nível alto para baixo. Isto pode ser utilizado para interromper um processador, ou ainda, sinalizar o resultado de uma nova conversão. A operação de leitura (RD), com o CS em nível baixo, irá limpar a linha INTR e habilitar a saída dos latches. O dispositivo também funciona de forma independente. Conversões em curso podem ser interrompidas por um novo comando de inicialização. A Figura 33 traz o diagrama em blocos e a pinagem do ADC 0803.

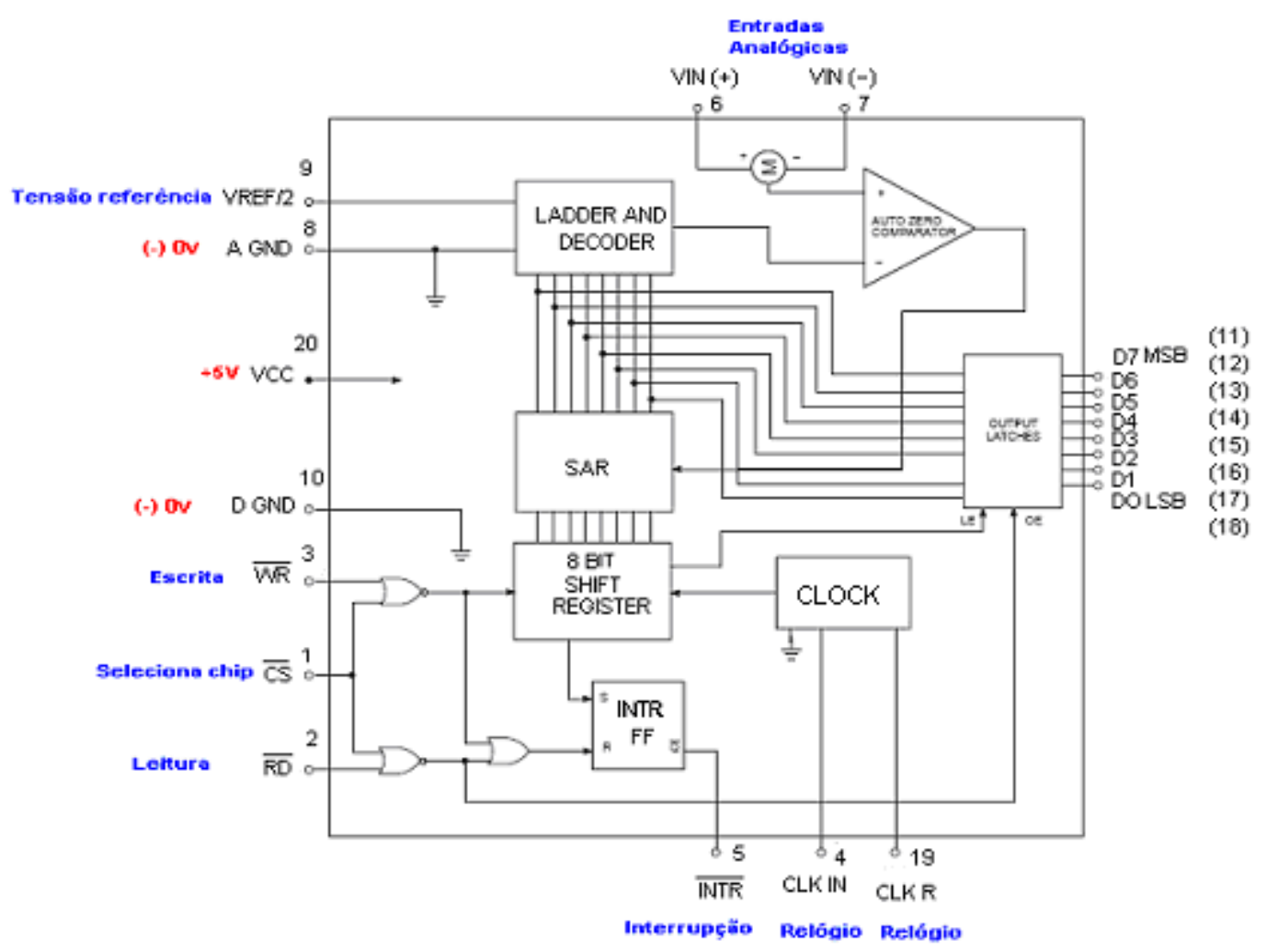

Figura 33: Diagrama interno do cornversor A/D ADC 0803.

O sinal de clock ADC0803 pode ser de fonte externa, tal como um sistema de clock, ou um auto-clock, através da adição de um capacitor e um resistor. O cálculo do valor 
da freqüência de clock e a configuração da rede $\mathrm{RC}$ estão disponíveis na Figura 34. A Figura 35 contém o esquema de interligação dos conversores A/D.

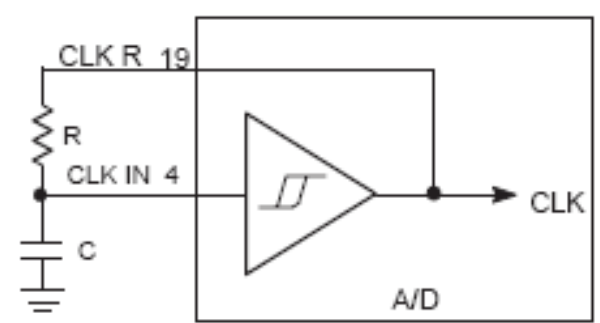

Figura 34: Gerador de clock do ADC0803.

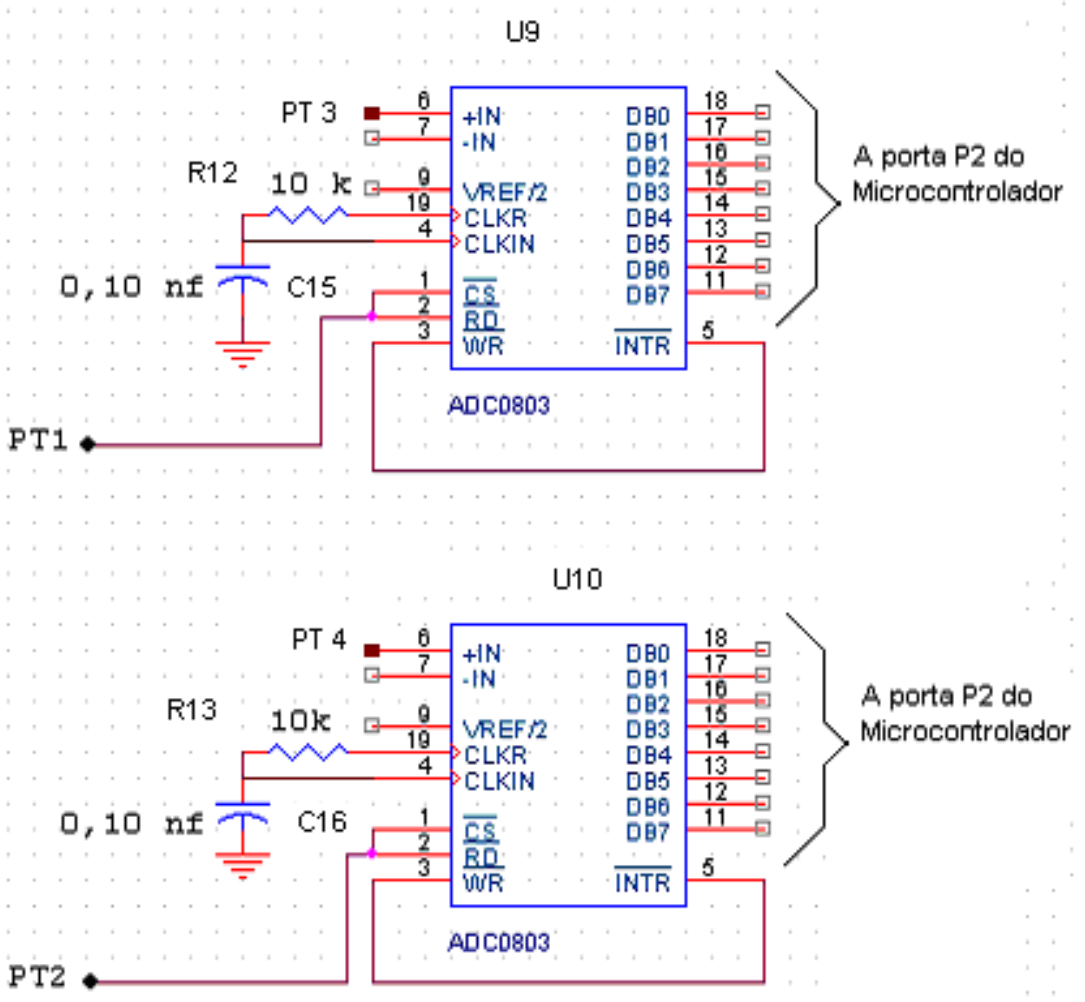

Figura 35: Esquema de interligação do ADC0803 


\section{Conversor Corrente Tensão}

Quando se deseja converter uma corrente fornecida por um dispositivo qualquer, como por exemplo, um fotodiodo, em uma tensão, pode-se fazer uso dos conversores de corrente tensão, ou também conhecidos como amplificador de transimpedância ou transresistência, já que a constante que relaciona a saída com a entrada é uma resistência. A Figura 36 mostra um conversor corrente tensão simples.

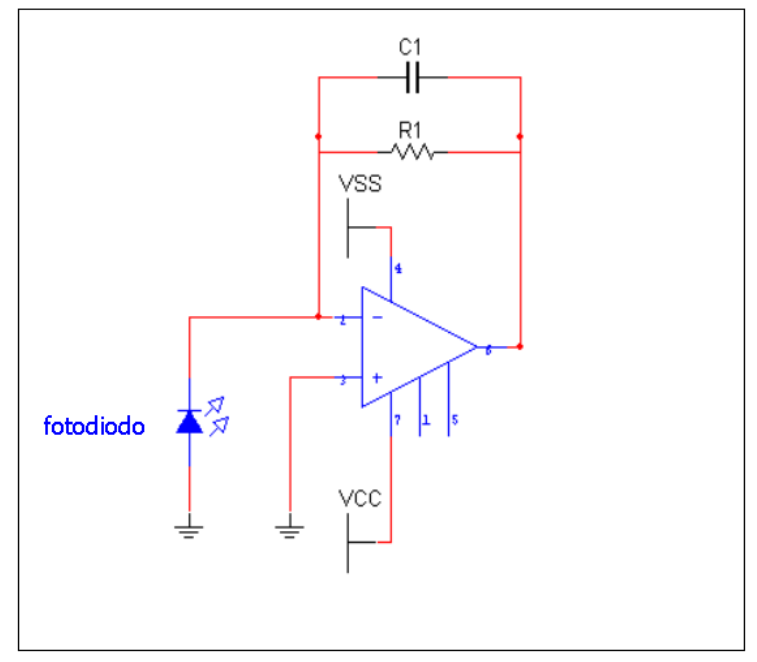

Figura 36: Conversor corrente - tensão.

A polaridade de $V_{o}$ depende da direção de $I_{s}$.

\section{Amplificadores para fotodetectores}

Uma das aplicações mais freqüentes de conversores I-V é em conexão com fotodetectores do tipo corrente, tais como fotodiodos e fotomultiplicadores. Por isso esta é a configuração utilizada no projeto para converter a corrente, que vem do fotodiodo (sensor de silício), em tensão.

Como já dito anteriormente, fotodetectores são transdutores que produzem uma corrente elétrica como resposta à luz incidente. Um amplificador de transresistência é então usado para converter essa corrente em uma tensão. 
Os fotodiodos PIN são ligados de modo a funcionar como fontes de corrente. As correntes geradas pelos fotodiodos são aplicadas a um conversor corrente tensão, como mostrado na Figura 37.

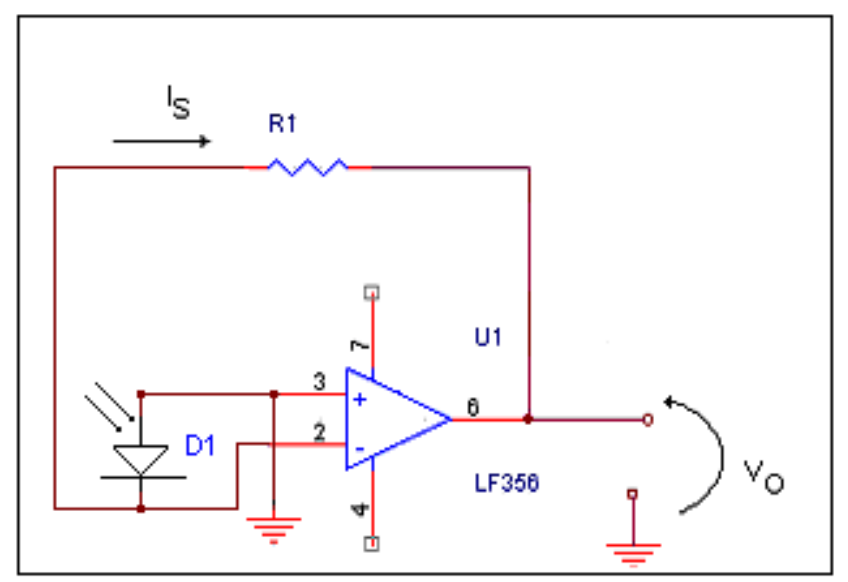

Figura 37: Esquema do conversor corrente tensão com fotodiodo

\section{Filtro Ativo}

Para controlar o ruído no sistema foi utilizado um filtro ativo passa - baixa de ordem 2.

Filtros ativos são construídos com alguns elementos passivos associados a elementos ativos (válvulas, transistores ou amplificadores operacionais). A alta resistência de entrada e a baixa resistência de saída dos amplificadores operacionais, associados as suas outras características, permitem a implementação de filtros de ótimas qualidades.

Existem inúmeras estruturas de implementação para filtros ativos. No projeto foi utilizado a estrutura de fonte de tensão controlada por tensão que costuma também ser denominada estrutura de Sallen e Key, pois possui boa estabilidade, baixa impedância de saída, facilidade de ajuste de ganho e de freqüência.

A implementação do filtro PB de segunda ordem, utilizando a estrutura Sallen Key está indicada na Figura 38. 


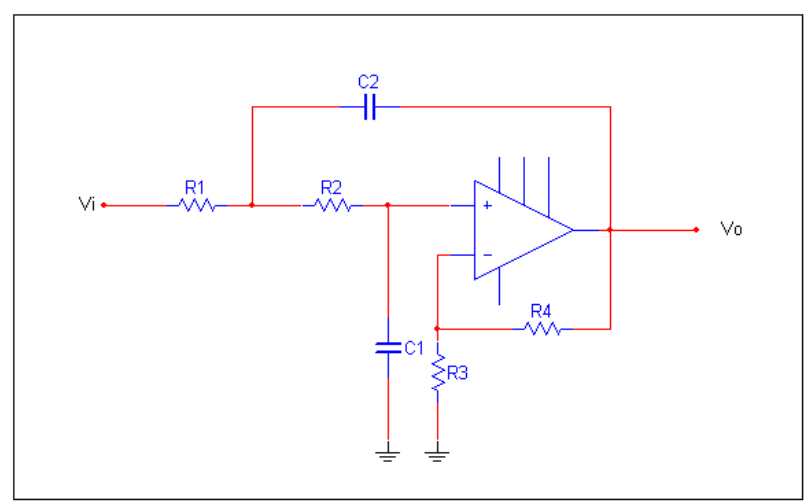

Figura 38 - Filtro Ativo Passa Baixa.

As equações de projeto para esse filtro são [Smith, K. C.; Sedra, A. S.; 1999]:

$$
K=1+\frac{R_{4}}{R_{3}}
$$

Onde R1, R2, R3 e R4 são os resistores, com valores:

$$
\begin{gathered}
R_{1}=\frac{2}{\left[a C_{2}+\sqrt{\left[a^{2}+4 b(K-1)\right] C_{2}^{2}-4 b C_{1} C_{2}}\right] \omega_{c}} \\
R_{2}=\frac{1}{b C_{1} C_{2} R_{1} \omega_{c}^{2}} \\
R_{3}=\frac{K\left(R_{1}+R_{2}\right)}{K-1}
\end{gathered}
$$

Se $K=1, R_{3}$ deverá ser "aberto" e $R_{4}$ será um curto circuito:

$$
R_{4}=K\left(R_{1}+R_{2}\right)
$$

Os parâmetros a e b são obtidos na Tabela 3:

Tabela 3: Parâmetros a e b para filtro ativo de ordem 2

\begin{tabular}{|c|c|c|}
\hline $\mathrm{n}$ & $\mathrm{a}$ & $\mathrm{b}$ \\
\hline 2 & 1,414214 & 1 \\
\hline
\end{tabular}




\section{Amplificador não inversor}

A configuração em malha fechada não inversora está mostrada na Figura 39.

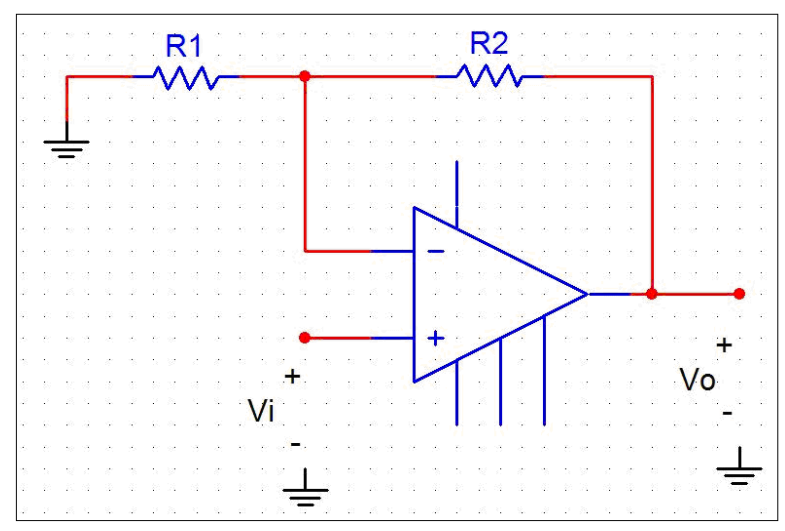

Figura 39: Esquemático do amplificador não inversor.

Nesta malha, o sinal de entrada $\mathrm{V}_{\mathrm{i}}$, proveniente da saída do conversor corrente tensão, é aplicado diretamente ao terminal de entrada positivo do amplificador operacional, enquanto um dos terminais de $\mathrm{R}_{1}$ é conectado ao terra.

O Efeito de um Ganho Finito em Malha Fechada [Smith, K. C.; Sedra, A. S.; 1999]

Supondo que o amplificador operacional seja ideal, com ganho infinito, há um curto-circuito virtual entre seus dois terminais de entrada. Portanto, a diferença dos sinais de entrada é:

$$
V_{+}-V_{-}=\frac{V_{o}}{A}=0 \text { para } A=\infty
$$

Logo, a tensão no terminal da entrada inversora será igual à do terminal da entrada não inversora, no qual está aplicada a tensão $V_{i}$.

A corrente através de $R_{1}$ pode ser determinada por $V_{i} / R_{1}$. Pelo fato de $a$ impedância de entrada do amplificador operacional ser infinita, essa corrente circulará por $\mathrm{R}_{2}$. Agora a tensão de saída pode ser determinada por

$$
V_{o}=V_{i}+\left(\frac{V_{i}}{R_{1}}\right) R_{2}
$$


Ou ainda,

$$
\frac{V_{o}}{V_{i}}=1+\frac{R_{2}}{R_{1}}
$$

Uma nova abordagem sobre a operação da configuração não-inversora pode ser obtida das seguintes considerações: o divisor de tensão no caminho da realimentação negativa faz com que uma fração da tensão de saída apareça no terminal da entrada inversora do amplificador operacional; isto é

$$
V_{i}=V_{o}\left(\frac{R_{1}}{R_{1}+R_{2}}\right)
$$

Então, o ganho infinito do amplificador operacional e o curto-circuito resultante entre os dois terminais de entrada forçam essa tensão a ser igual à do terminal da entrada positiva:

$$
V_{o}\left(\frac{R_{1}}{R_{1}+R_{2}}\right)=V_{i}
$$




\section{Desenvolvimento do Protótipo}

Em virtude da linearidade do sensor informada pelo fabricante; da utilização de um conversor corrente-tensão linear para baixas freqüências; e de um amplificador não inversor linear; a tensão na saída do amplificador, a ser aplicada na entrada do AD, será diretamente proporcional à intensidade luminosa incidente no fotodetector.

De acordo com o gráfico da Figura 40, reproduzido a partir do datasheet do fabricante, foi constatado que o sensor é linear até por volta de $2 \mathrm{~V}$.

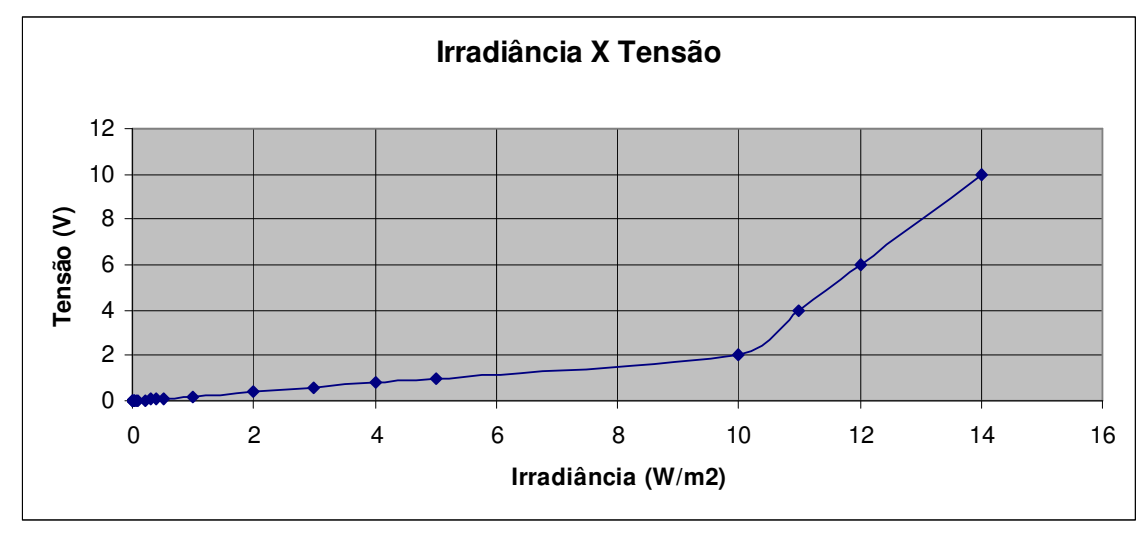

Figura 40 - Gráfico de Irradiância x Tensão do fotodiodo.

A tensão de saída máxima medida na saída do sensor foi de $100 \mathrm{mV}$, assim, pode-se concluir que o sensor é linear na região de operação do sistema.

Como a intensidade luminosa também é dependente do nível de proteção nos espectros UVA e UVB correspondentes, ocorre uma relação proporcional direta entre a tensão de saída e o nível de proteção da lente.

Para medir a intensidade de luz nas duas regiões distintas, UVA e UVB, foram utilizados os dois sensores mencionados.

O nível de corrente gerada pela luz incidente sobre um fotodiodo não é suficiente para que ele possa ser usado em um controle direto, sendo necessário para isto que haja um estágio de amplificação como mostrado na Figura 41. 


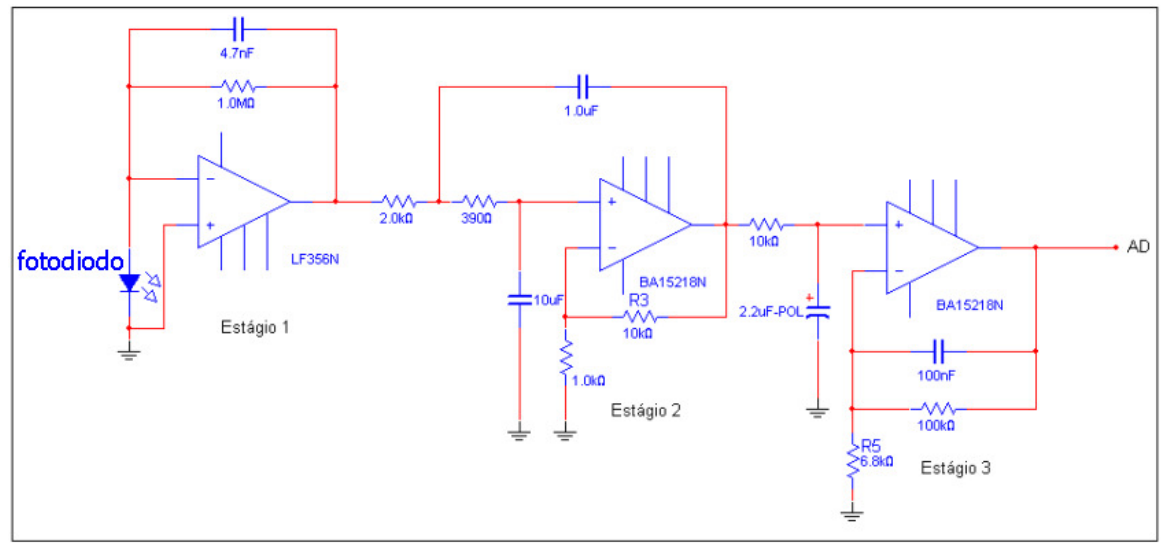

Figura 41 - Esquemático dos estágios amplificadores.

No estágio 1, como mostra a Figura 42, o sinal proveniente do fotodiodo (que pode ser modelado como uma fonte de corrente) é convertido em tensão.

Para montar o conversor corrente - tensão foi utilizado o amplificador operacional LF356N, que é um componente de baixo custo e que possui alta impedância de entrada e baixo off-set, com rejeição de 100 dB.

Os valores de resistência $(R=2,2 \mathrm{M} \Omega)$ e capacitância $(47 \mathrm{nF})$ foram obtidos experimentalmente.

O valor do resistor usado é alto, pois a constante que relaciona a tensão com a corrente é a resistência, e a corrente que vêm do fotodiodo é muito pequena.

Os pinos 1 e 5 do amplificador são utilizados para fazer o ajuste de off-set do circuito.

Foi usado um capacitor para controlar o ruído do sinal (sinal da saída do conversor muito ruidoso). No estágio 2, o sinal é filtrado por um filtro ativo passa - baixa de ordem 2.

Para os estágios de filtragem e amplificação foi utilizado o circuito integrado BA15218N, que possui dois amplificadores operacionais no mesmo integrado.

O filtro foi calculado para uma freqüência de corte de $60 \mathrm{~Hz}$ para eliminar o ruído causado pela pulsação da lâmpada na freqüência da rede.

Os valores de resistência e de capacitância utilizados no filtro ativo foram calculados através das equações $(1-5)$. 


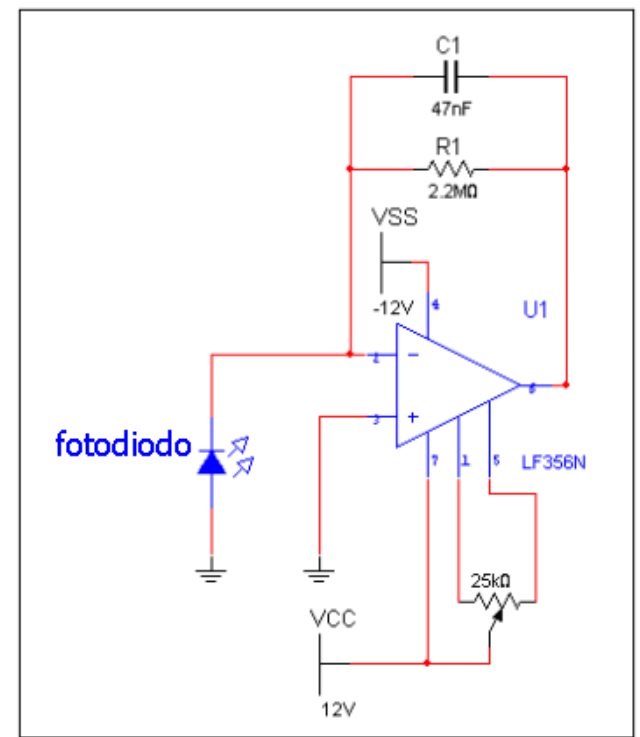

Figura 42 - Estágio 1 : Conversor corrente - tensão.

A Figura 43 mostra em detalhes o estágio 2.

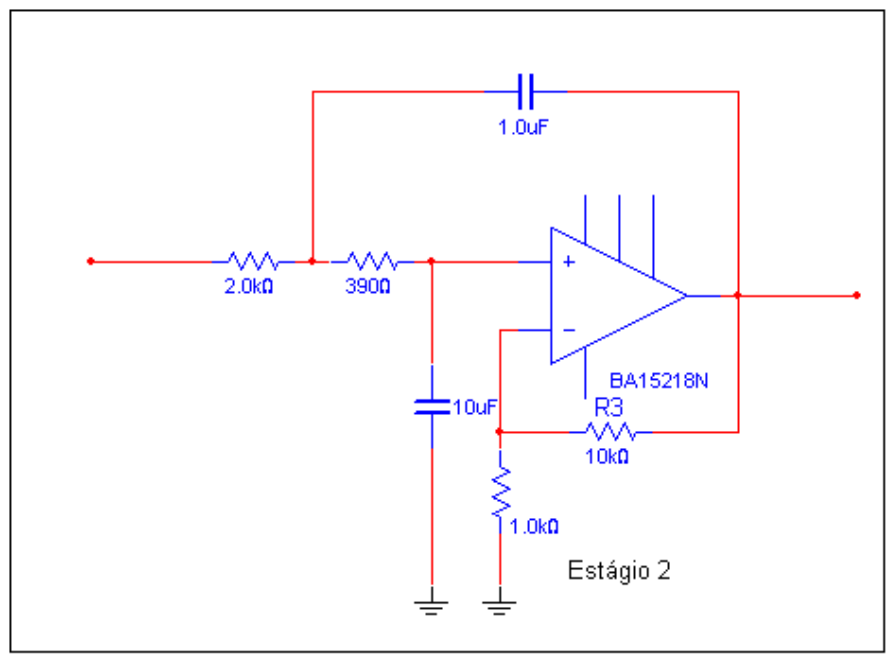

Figura 43 - Estágio 2 : Filtro Passa Baixa.

Na saída do filtro ativo, o sinal passa por um filtro RC como mostra a Figura 44. O filtro possui freqüência de corte $\left(w_{c}\right)$ de 1/RC.

No terceiro e último estágio, mostrado na Figura 45 , tem - se um circuito amplificador integrador Miller [Smith, K. C.; Sedra, A. S.; 1999]. 


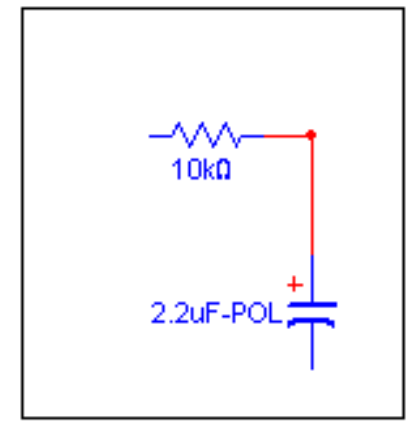

Figura 44 - Filtro RC

O amplificador possui ganho CC de $1+(100 \mathrm{k} / 6.8 \mathrm{k})$, de aproximadamente 16X e freqüência de corte dada por 1/RC.

Com esses valores, os ganho total, dos estágios 2 e 3, é de aproximadamente 147X, proporcionando, desta forma, uma tensão de saída de $4 \mathrm{~V}$, como pode ser observado na Figura 46, que mostra o sinal após a saída do último estágio.

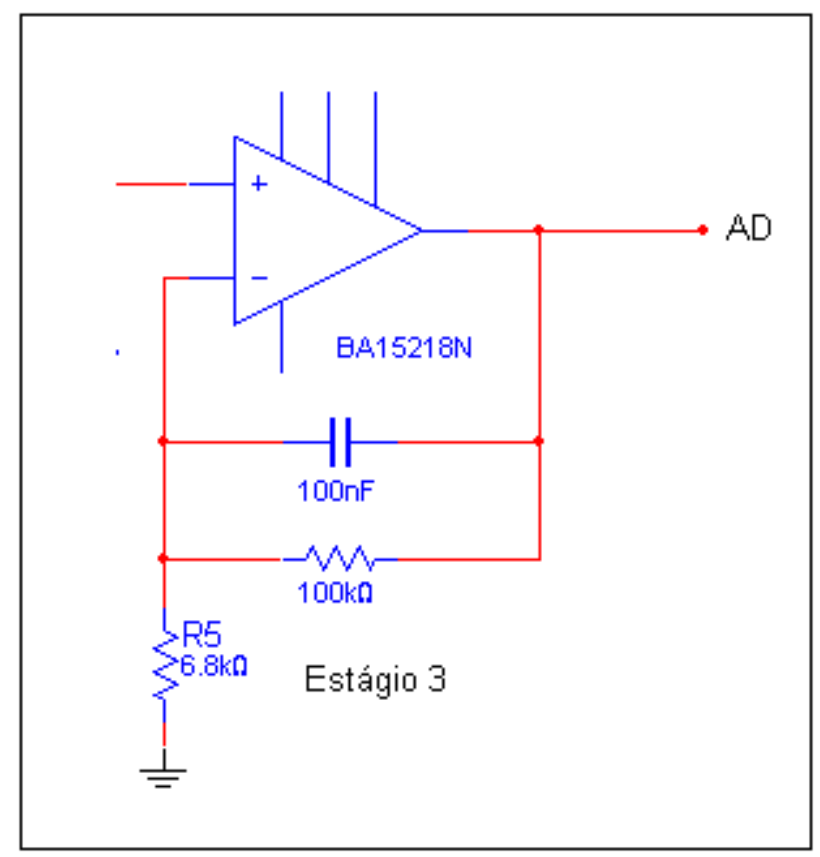

Figura 45: Estágio 3: Amplificador Integrador Miller 


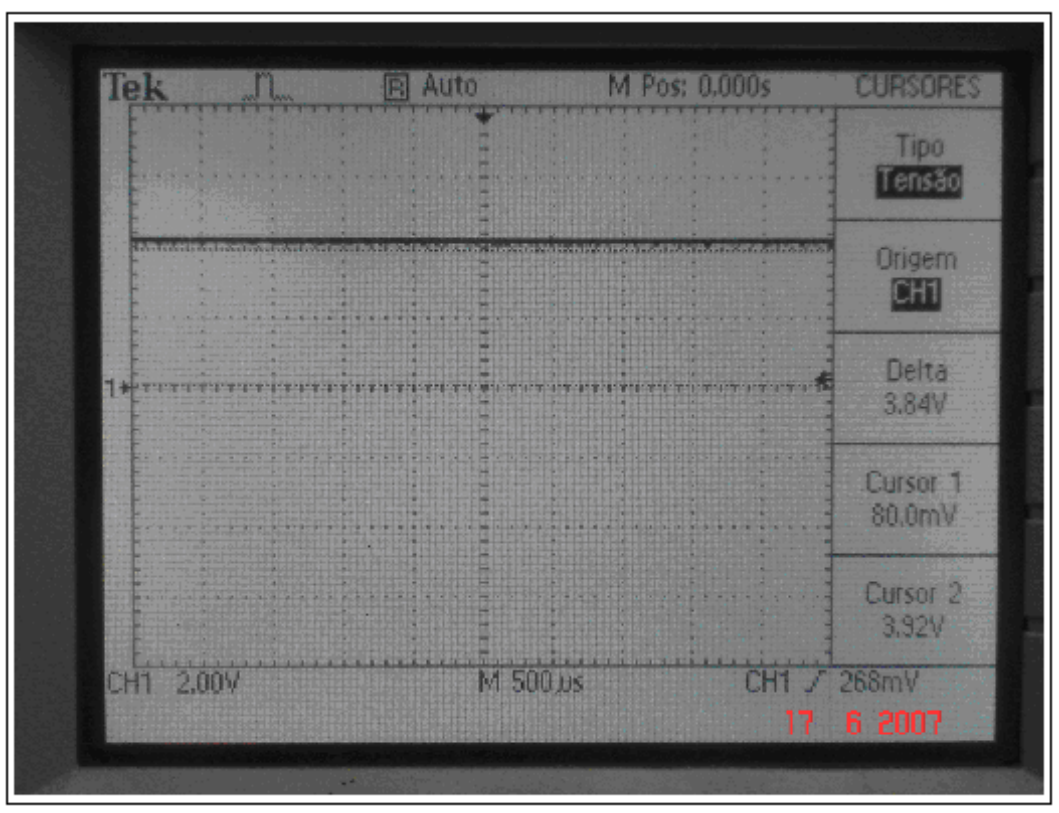

Figura 46: Sinal de saída do último estágio.

Nas Figuras 47 e 48, pode-se observar o sistema em bancada.

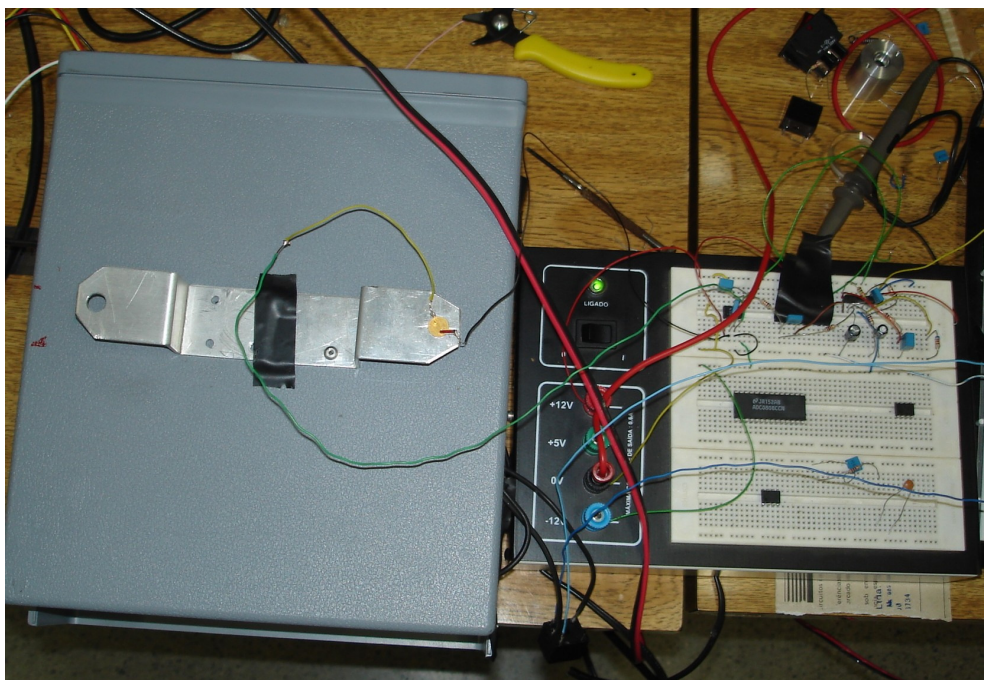

Figura 47: Sistema eletrônico. 


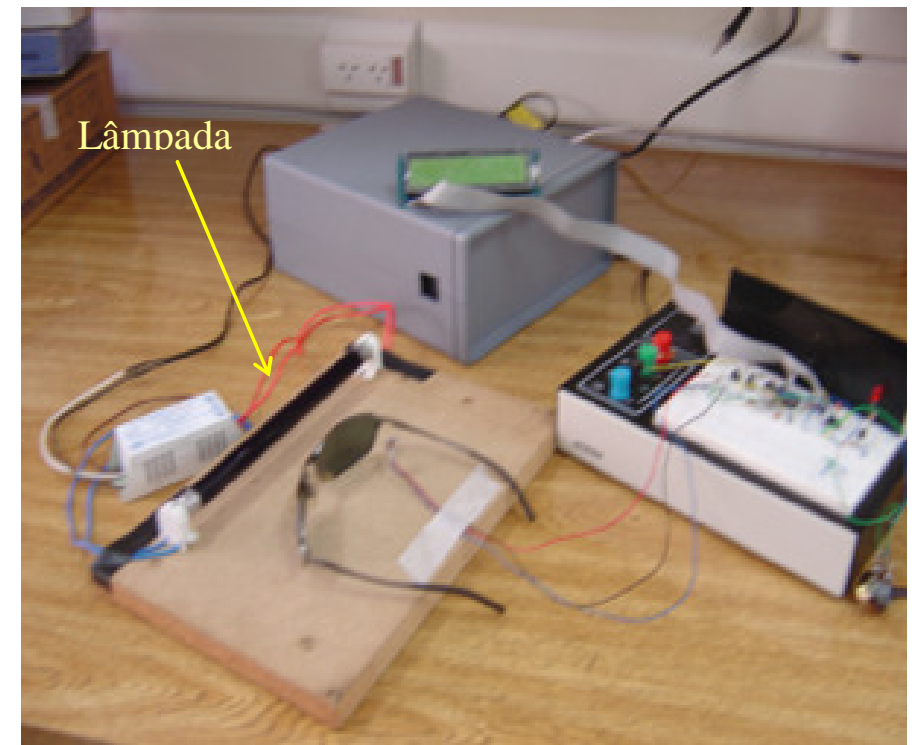

Figura 48: Caixa funcional, sistema eletrônico e lâmpada BLB. 


\section{Parte Digital}

\section{Microcontrolador}

O microcontrolador utilizado no projeto é o AT89S52 da Atmel (Figura 49), que é de baixíssimo consumo de potência, CMOS de alto desempenho, com 8 Kbytes de memória flash programável. O dispositivo é fabricado utilizando tecnologia de alta densidade e é compatível com o conjunto de instruções e pinagem do $89 \mathrm{C} 51$, de acordo com o datasheet do fabricante. A memória flash on-chip permite programar a memória de programa in-circuit ou por um programador de memória convencional.

O 89552 tem como principais características:

- $8 \mathrm{k}$ bytes de memória flash;

- 256 bytes de RAM;

- 32 portas de $\mathrm{I} / \mathrm{O}$;

- 3 timers / contadores de 16 bits;

- porta serial full duplex.

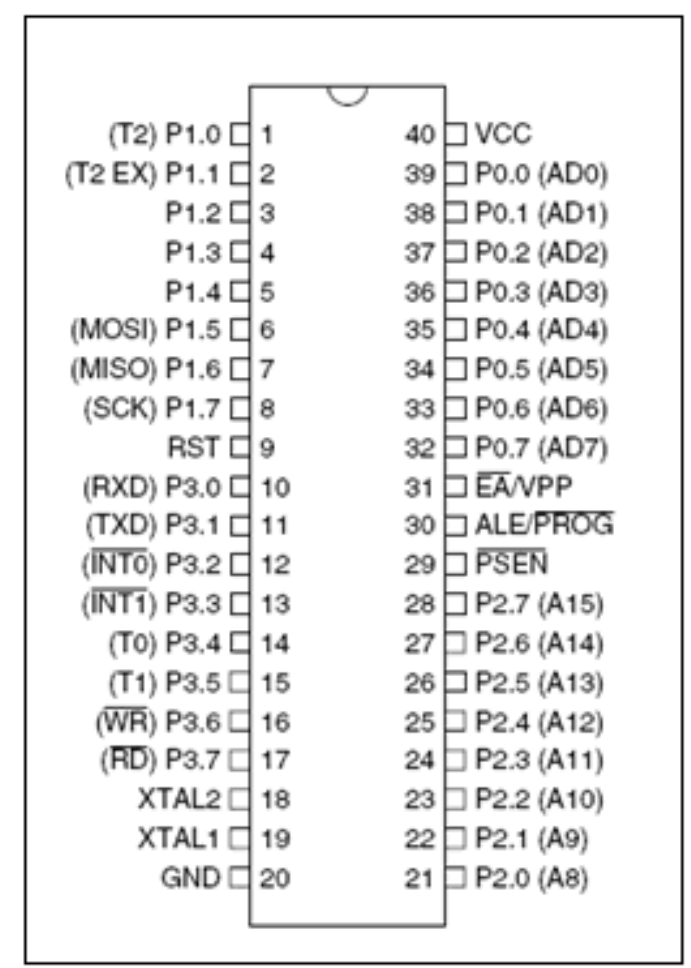

Figura 49 - Pinagem do microcontrolador AT89S52. 
As conexões com as portas de $\mathrm{I} / \mathrm{O}$ do microcontrolador foram feitas de modo a deixar a porta apenas como entrada ou apenas como saída, para evitar erros ou conflitos. Deste modo, as portas P0, P2 e P3 estão apenas como saídas, enquanto que P1 está apenas como entrada.

LCD

O LCD é um dispositivo de saída utilizado nesse projeto para exibir ao usuário o resultado da medição UV da lente e os menus de navegação. O LCD utilizado é o JHD 162 A, que segue o padrão HD44780 e está mostrado na Figura 50.

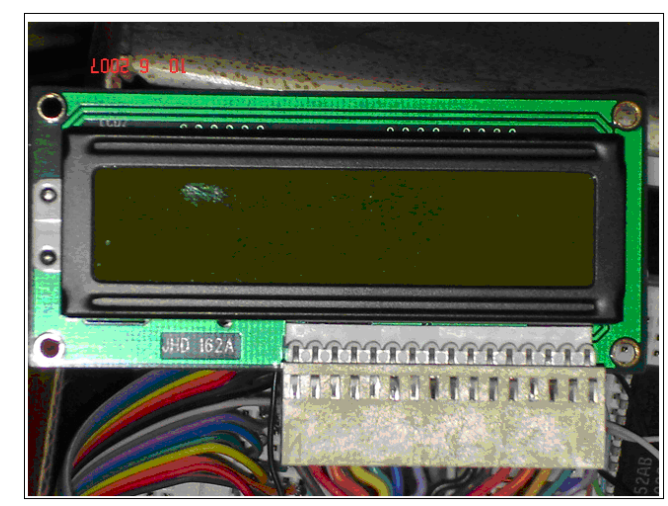

Figura 50: Foto do LCD utilizado.

O HD44780 possui dois registradores de 8 bits, um registrador de instrução (IR) e um registrador de dados (DR). O registrador de instrução é responsável pelas operações de configuração, rolagem de tela, posicionamento do cursor, entre outras. $O$ registrador de dados contém o dado que deve ser escrito no LCD.

O padrão HD44780 requer três linhas de controle e também quatro ou oito linhas de I/O para o duto de dados. No caso do projeto foram utilizadas oito linhas de I/O para o duto de dados. Quando o display LCD não está habilitado, as linhas de dados tristate assumem o estado de alta impedância (como se estivessem desligadas do circuito), de modo que, não interferem com o funcionamento do microcontrolador.

O LCD baseado no controlador Hitachi HD44780 ou equivalente possui a seguinte pinagem e sugestão de ligação, mostradas na Erro! Fonte de referência não encontrada.51. 


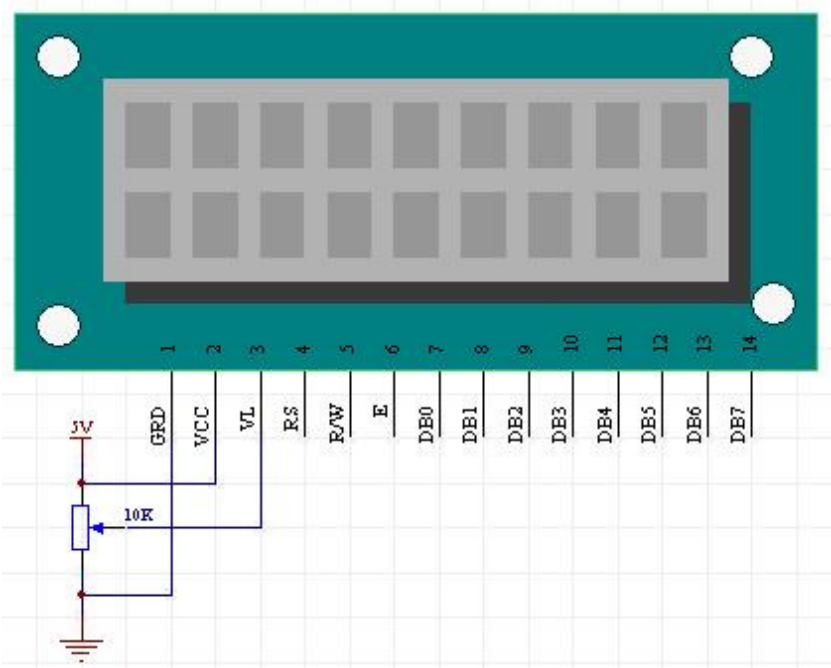

Figura 51: Pinagem do LCD.

As funções de cada pino estão descritas na Tabela 4:

Tabela 4- Funções de cada pino do LCD JHD 162 a

\begin{tabular}{|l|l|}
\hline Pino & Função \\
\hline 1 & Terra \\
\hline 2 & Alimentação positiva (Vcc) \\
\hline 3 & Tensão de contraste \\
\hline 4 & Seleção de registrador \\
\hline 5 & Leitura ou Escrita \\
\hline 6 & Habilita/Desabilita \\
\hline 7 ao 14 & Barramento de dados bidirecional \\
\hline
\end{tabular}

A linha Enable (E) permite a ativação do display e a utilização das linhas R/W (Read/Write) e RS (Register Select). Quando a linha de "habilitar" (Enable) está em nível baixo, o LCD fica inibido e ignora os sinais R/W e RS. Quando (E) está em nível alto, o LCD verifica os estados das duas linhas de controle e responde de acordo com estes.

A linha R/W determina o sentido dos dados entre o microcontrolador e o LCD. Quando está em nível baixo, os dados serão escritos no LCD. Quando está em nível alto, os dados serão lidos do LCD.

Com a ajuda da linha de RS, o LCD interpreta o tipo de dados presentes nas linhas de dados. Quando está em nível baixo, uma instrução será escrita no LCD. Quando está em nível alto, será escrito um caractere no LCD. 
A Tabela 5 apresenta o estado lógico nas linhas de controle.

Tabela 5 - Estado lógico nas linhas de controle do LCD.

\begin{tabular}{|l|l|l|}
\hline Linha de Controle & Nível Lógico & Estado \\
\hline \multirow{2}{*}{ E } & 0 & Acesso ao LCD desabilitado \\
\cline { 2 - 3 } & 1 & Acesso ao LCD habilitado \\
\hline \multirow{2}{*}{ R/W } & 0 & Escrever dados no LCD \\
\cline { 2 - 3 } & 1 & Ler dados do LCD \\
\hline \multirow{2}{*}{ RS } & 0 & Instruções \\
\cline { 2 - 3 } & 1 & Caracteres \\
\hline
\end{tabular}

A escrita dos dados no LCD é feita em várias etapas:

1. Designar o bit $R / W$ em nível baixo

2. Designar o bit $R S$ em nível lógico 0 (instrução) ou em nível lógico 1 (caractere)

3. Colocar o dado na linha de dados (se for uma operação de escrita)

4. Designar a linha $E$ em nível alto

5. Designar a linha $\mathrm{E}$ em nível baixo

6. Ler o dado das linhas de dados (no caso de uma operação de leitura)

\section{Controle da Lâmpada BLB}

O controle da lâmpada BLB é feito por um relé comum - Figura 52. Para chavear a tensão de $5 \mathrm{~V}$ no comando do relé (K1), há o transistor Q1. Se o sinal de LAMP estiver em nível 0 , o transistor não conduzirá, e o relé estará com $0 \mathrm{~V}$. Se o sinal de LAMP estiver em 1, o relé também estará em 1 com o chaveamento do transistor. $O$ microcontrolador controla via software a variável LAMP.

Finalmente, o conector JP2 é ligado em série com um fio de alimentação da lâmpada (de preferência a fase). Deste modo, o relé controla se a lâmpada está ligada ou desligada. 


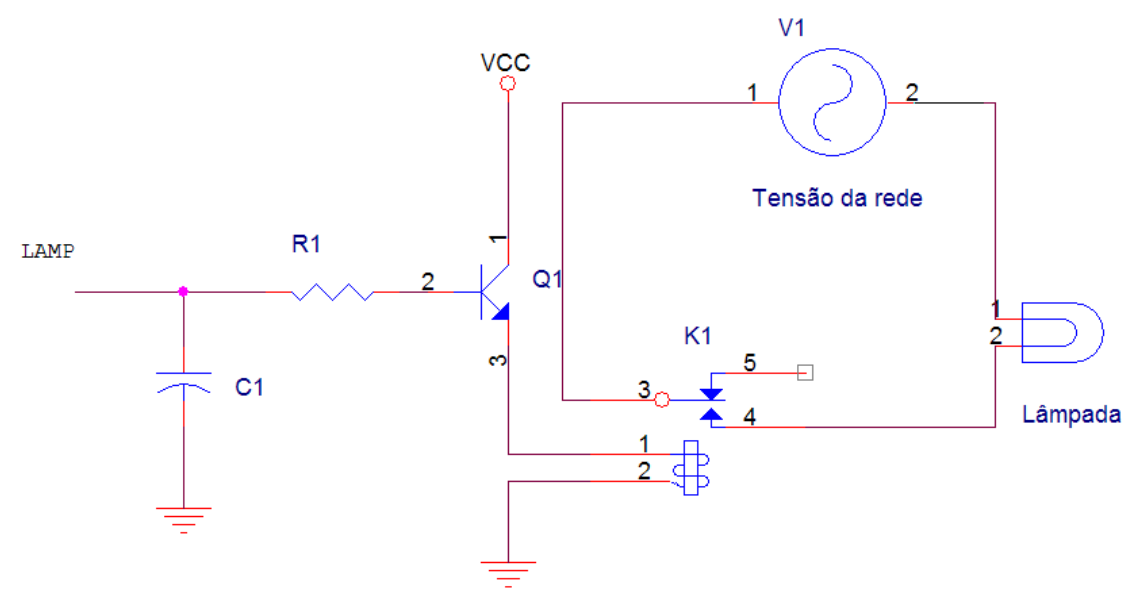

Figura 52 - Esquemático do acionamento da lâmpada BLB

\section{Conversor Analógico Digital (AD)}

O AD utilizado na aplicação é o ADC0808 da National Semiconductor. É um AD de 8 bits de resolução com fonte de alimentação simples, tempo de conversão de $100 \mu \mathrm{s}$ e consumo de apenas $15 \mathrm{~mW}$ de potência. Além disso, não necessita de ajuste de zero ou de fundo de escala para as conversões, sendo um AD de 8 canais multiplexados, com endereçamento lógico.

A Figura 53 mostra a pinagem do AD utilizado.

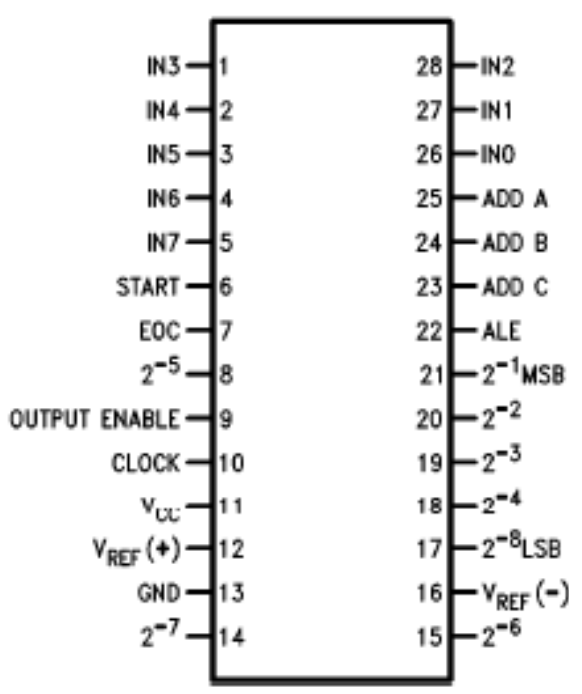

Figura 53 - Pinagem do conversor ADC0808.

A Tabela 6 apresenta a pinagem e a função de cada um dos pinos do integrado. 
Tabela 6 - Pinagem e funções do ADC0808.

\begin{tabular}{|c|c|c|}
\hline Pino & Nome & 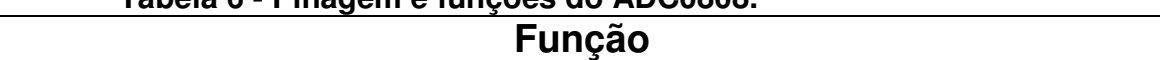 \\
\hline 01 & IN3 & Entrada analógica \#3. \\
\hline 02 & IN4 & Entrada analógica \#4. \\
\hline 03 & IN5 & Entrada analógica \#5. \\
\hline 04 & IN6 & Entrada analógica \#6. \\
\hline 05 & IN7 & Entrada analógica \#7. \\
\hline 06 & Start & Início da conversão. \\
\hline 07 & EOC & $\begin{array}{l}\text { End of conversion. O pino vai para nível lógico zero depois do } \\
\text { pulso de Start, fica assim durante toda a conversão e volta para } \\
\text { nível alto após a conversão. }\end{array}$ \\
\hline 08 & DB3 & Saída de dados \#3. \\
\hline 09 & OE & $\begin{array}{l}\text { Output Enable. Quando } \mathrm{OE}=0, \quad \text { DB0-DB7 } \\
\text { impedância: } O E=1 \text {, DB0-DB7 são em saídas ativas. }\end{array}$ \\
\hline 10 & CLK & Entrada do sinal de clock para o AD. \\
\hline 11 & $\mathrm{~V}_{\mathrm{cc}}$ & Alimentação positiva. \\
\hline Pino & Nome & Função \\
\hline 12 & $+V_{\text {ref }}$ & Tensão de referência positiva. \\
\hline 13 & GND & $\begin{array}{l}\text { Terra. Todas as entradas e saídas analógicas e digitais são } \\
\text { referentes a esse nível de tensão. }\end{array}$ \\
\hline 14 & DB1 & Saída de dados \#1. \\
\hline 15 & DB2 & Saída de dados \#2. \\
\hline 16 & $-V_{\text {ref }}$ & Tensão de referência negativa. \\
\hline 17 & DB0 & Saída de dados \#0. \\
\hline 18 & DB4 & Saída de dados \#4. \\
\hline 19 & DB5 & Saída de dados \#5. \\
\hline 20 & DB6 & Saída de dados \#6. \\
\hline 21 & DB7 & Saída de dados \#7. \\
\hline 22 & ALE & $\begin{array}{l}\text { Address Latch Enable. Quando é aplicado um pulso nesse pino, } \\
\text { são lidos os níveis de tensão em ADDR0-2 e selecionada a } \\
\text { entrada (IN1-7) para conversão. }\end{array}$ \\
\hline 23 & ADDR0 & $\begin{array}{l}\text { Endereço de entrada para o multiplexador. Sinal para seleção da } \\
\text { entrada analógica. }\end{array}$ \\
\hline 24 & ADDR1 & $\begin{array}{l}\text { Endereço de entrada para o multiplexador. Sinal para seleção da } \\
\text { entrada analógica. }\end{array}$ \\
\hline 25 & ADDR2 & $\begin{array}{l}\text { Endereço de entrada para o multiplexador. Sinal para seleção da } \\
\text { entrada analógica. }\end{array}$ \\
\hline 26 & IN0 & Entrada analógica \#0. \\
\hline 27 & IN1 & Entrada analógica \#1. \\
\hline 28 & IN2 & Entrada analógica \#2. \\
\hline
\end{tabular}


A entrada do sinal analógico a ser convertido para digital deve ser aplicada em um dos pinos de entrada identificados por IN $x$, em que $x$ é o número da entrada que será utilizada. Apesar de a entrada poder ser aplicada em 8 pinos diferentes, a saída sempre será vista nos pinos com indicação $2^{-y}$, onde y é o nível do bit em relação ao fundo de escala. $O$ bit em que $y=1$ corresponde ao bit mais significativo (MSB) e o bit em que $y=8$ corresponde ao bit menos significativo da conversão (LSB). Para identificar qual entrada está sendo utilizada, devem-se utilizar os pinos de endereçamento ADD A, ADD B e ADD C, de acordo com a Tabela 7

Tabela 7 - Seleção de entradas do ADC0808

\begin{tabular}{|c|c|c|c|}
\hline \multirow{2}{*}{ Entrada Selecionada } & \multicolumn{3}{|c|}{ ADD } \\
\cline { 2 - 4 } & C & B & A \\
\hline IN 0 & 1 & 1 & 1 \\
\hline IN 1 & 1 & 1 & 0 \\
\hline IN 2 & 1 & 0 & 1 \\
\hline IN 3 & 1 & 0 & 0 \\
\hline IN 4 & 0 & 1 & 1 \\
\hline IN 5 & 0 & 1 & 0 \\
\hline IN 6 & 0 & 0 & 1 \\
\hline IN 7 & 0 & 0 & 0 \\
\hline
\end{tabular}

Após selecionar a entrada através dos pinos de endereçamento, é preciso dar um pulso no pino ALE (Address Latch Enable), para que o microcontrolador faça a leitura dos pinos ADD A, ADD B e ADD C e "saiba" a partir de qual entrada a conversão deve ser feita. Então, a conversão iniciar-se-á com um pulso no pino de START, a partir da entrada selecionada nos pinos, no momento do pulso em ALE. Durante a conversão, o pino EOC estará em nível baixo. Ao término desta, o pino EOC assumirá o valor digital "1", e o resultado será obtido digitalmente nos pinos de saída.

O diagrama de tempos do conversor pode ser visto na Figura 54. 


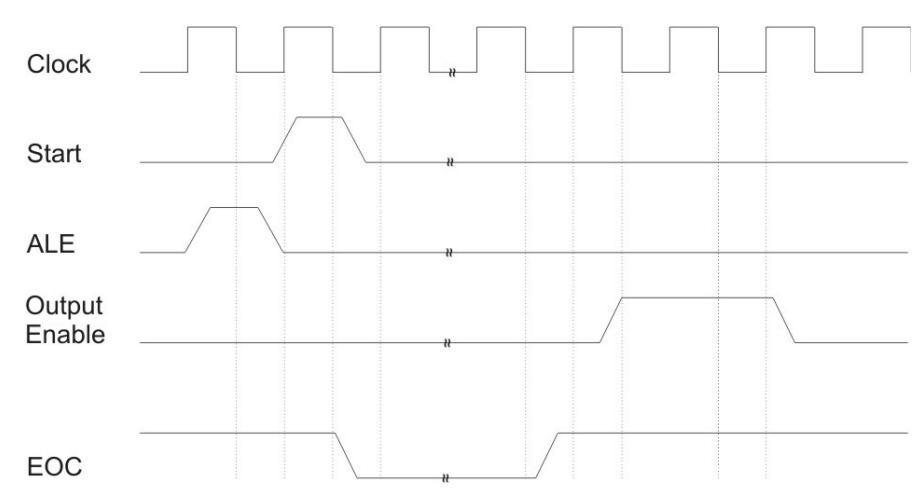

Figura 54 - Diagrama de tempos do conversor A/D utilizado.

Na Figura 55 e na Tabela 8 pode-se notar a linearidade do conversor AD e o baixo erro na tensão de saída.

Os dados da tabela foram medidos colocando na entrada do AD um sinal analógico proveniente de uma fonte comercial da marca Minipa, modelo MPC-303Di. Está fonte tem o inconveniente de não fornecer tensões menores que 0,25V. Foram ligados LEDs à saída do conversor, após fazer a leitura do sinal digital, este foi convertido para analógico novamente através da equação (11):

$$
V_{\text {analógico }}=\left(2^{-8}+2^{-7}+2^{-6}+2^{-5}+2^{-4}+2^{-3}+2^{-2}+2^{-1}\right) \times V_{f}
$$

onde, $V_{f}$ é o valor de fundo de escala do conversor A/D. Este valor de fundo de escala é a tensão aplicada no pino Vref+ quando Vref- é aterrado. Os coeficientes $2^{-y}$ da fórmula acima devem ser computados somente quando o bit no conversor $A / D$ correspondente à saída y estiver em nível alto, ou seja, 5 volts.

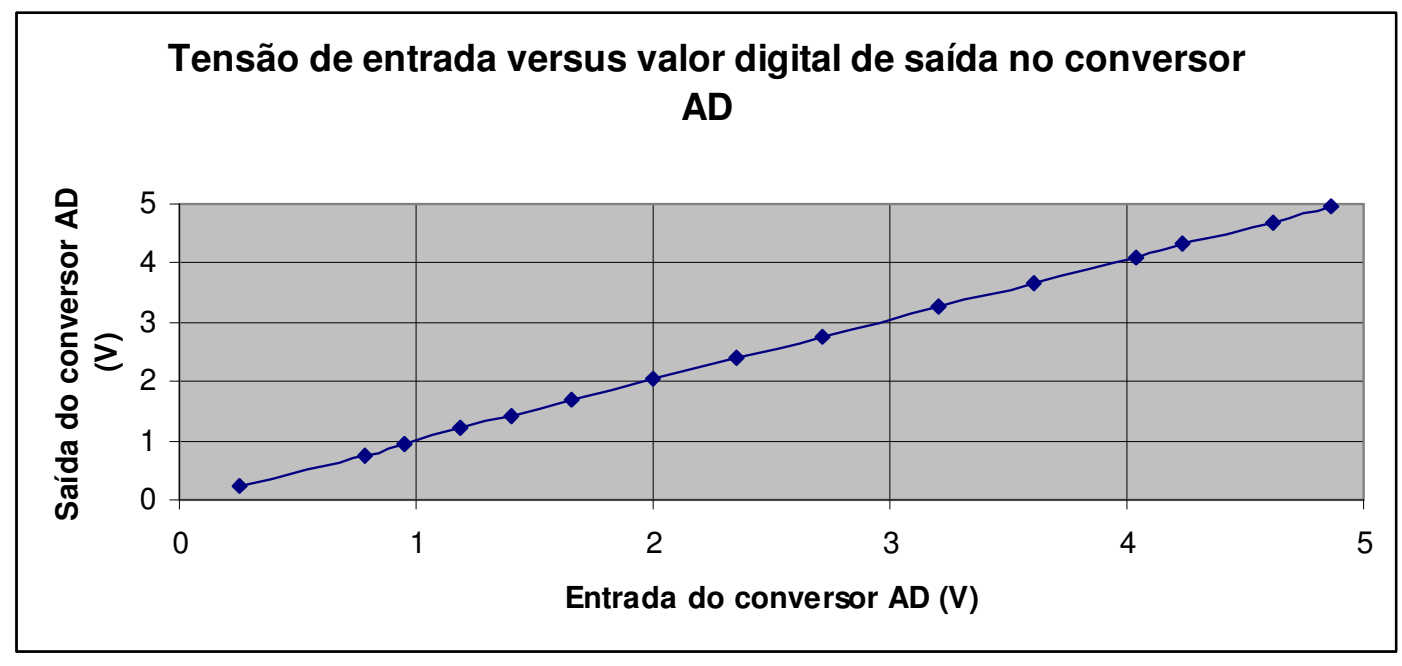

Figura 55 - Tensão de entrada versus valor digital na saída do conversor AD. 
Tabela 8 - Erros de conversão do AD

\begin{tabular}{|r|r|r|}
\hline $\begin{array}{c}\text { Entrada AD } \\
\text { (V) }\end{array}$ & $\begin{array}{c}\text { Saída AD } \\
\text { (V) }\end{array}$ & Erro \\
\hline & & \\
\hline 0,25 & 0,234375 & $6,25 \%$ \\
\hline 0,78 & 0,76171875 & $2,34 \%$ \\
\hline 0,95 & 0,95703125 & $0,74 \%$ \\
\hline 1,19 & 1,2109375 & $1,76 \%$ \\
\hline 1,4 & 1,42578125 & $1,84 \%$ \\
\hline 1,66 & 1,6796875 & $1,19 \%$ \\
\hline 2 & 2,03125 & $1,56 \%$ \\
\hline 2,35 & 2,3828125 & $1,40 \%$ \\
\hline 2,72 & 2,75390625 & $1,25 \%$ \\
\hline 3,21 & 3,26171875 & $1,61 \%$ \\
\hline 3,61 & 3,671875 & $1,71 \%$ \\
\hline 4,04 & 4,1015625 & $1,52 \%$ \\
\hline 4,24 & 4,31640625 & $1,80 \%$ \\
\hline 4,62 & 4,6875 & $1,46 \%$ \\
\hline 4,86 & 4,94140625 & $1,68 \%$ \\
\hline & &
\end{tabular}

Os A/Ds ADC0803 foram substituídos pelo ADC0808. Assim, foi implementado e montado um novo circuito como indicado na Figura 56.

As portas P0 do microcontrolador foram ligadas aos pinos de dados do display; a porta P1.0 foi ligada ao enable do displa; a porta P1.1 foi ligada ao pino $\boldsymbol{R S}$ do display; e a porta P1.2 foi ligada ao pino $\boldsymbol{R} \boldsymbol{W}$ do display. As portas P3.3, P3.4 e P3.5 foram ligadas aos botões ESC, UVA e UVB, respectivamente. Os circuitos ligados aos botões têm a função de eliminar ruídos. As portas P2 foram ligadas aos pinos de dados do conversor A/D. O circuito integrado U5 é um timer e sua função é gerar pulso de clock para o conversor A/D. O pino INO, do circuito integrado U3, foi ligado a saída do amplificador ligado ao fotodiodo UVA; e o pino IN1 foi ligado à saída do amplificador ligado ao fotodiodo UVB. O pino de referência positiva foi ligado a 5VCC, enquanto o pino de referência negativa foi ligado ao terra. Dessa forma, o ADC0808 trabalha com níveis de tensão máximo e mínimo iguais aos níveis ajustados nos amplificadores. 


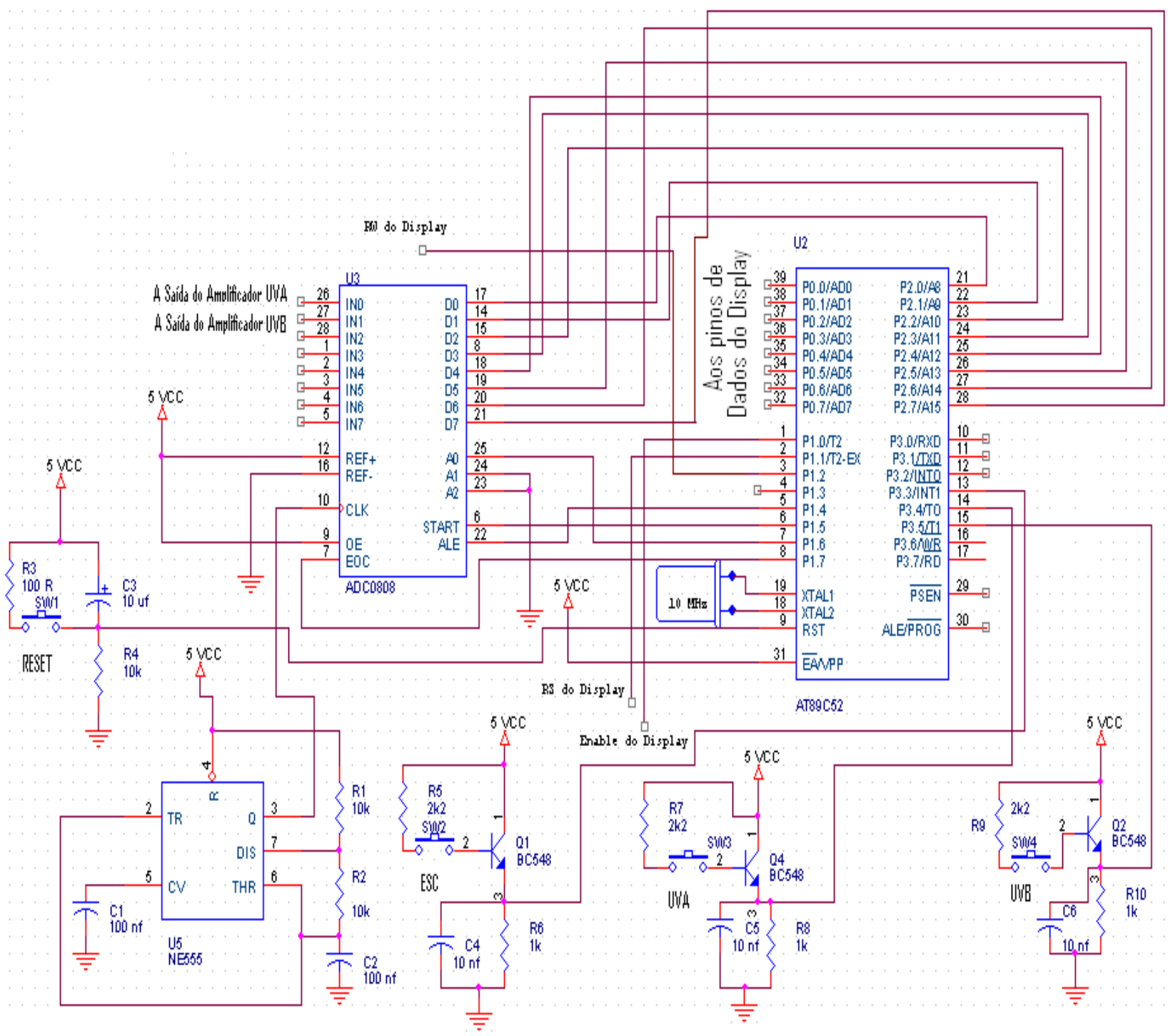

Figura 56: Diagrama do circuito definitivo do medidor de ultravioleta. 


\section{Rotina de controle do A/D}

O programa a seguir seleciona a entrada analógica, que se deseja converter para digital (pulso no pino ALE); inicia-se a conversão (pulso no pino START); esperase o fim da conversão (pino EOC); e armazena o resultado em uma variável (AD_RESP).

unsigned char $A D$ (unsigned char UV)

\{

$A D \_A L E=0$; // Coloca o pino em nível baixo

wait(10); // Função de espera

$A D \_S E L=U V ;$ // Seleciona no pino SEL do $A D$ qual lâmpada foi selecionada UVA $(U V=0)$

ou UVB (UV=1)

wait(2); // Função de espera

$A D \_A L E=1 ; / /$ Coloca o pino em nível alto

wait(10); // Função de espera

$A D \_A L E=0$; // Coloca o pino em nível baixo

wait(2); // Função de espera

$A D \_S T A R T=1 ;$ // Coloca o pino em nível alto

wait(10); // Função de espera

$A D \_S T A R T=0 ; / /$ Coloca o pino em nível baixo

while (!AD_EOC); // Espera o fim da conversão monitorando o $A D \_E O C$

$A D \_R E S P=P 2$; // Lê a porta $P 2$ e armazena o resultado em $A D \_R E S P$

return $A D \_R E S P$; // Retorna $A D \_R E S P$ como resultado da função

\}

Testes finais

Através de testes em bancada de laboratório, verificou-se que sem amostra, ou seja, com a intensidade total de luz atingindo o sensor, este apresenta uma tensão de saída de aproximadamente $5 \mathrm{~V}$ e com obstrução total da luz no sensor, apresenta 
tensão nula. Foram realizados alguns testes com o auxílio de potenciômetros para simular na entrada do AD o valor analógico modulado pelas lentes com proteção UV vide Figura 57.

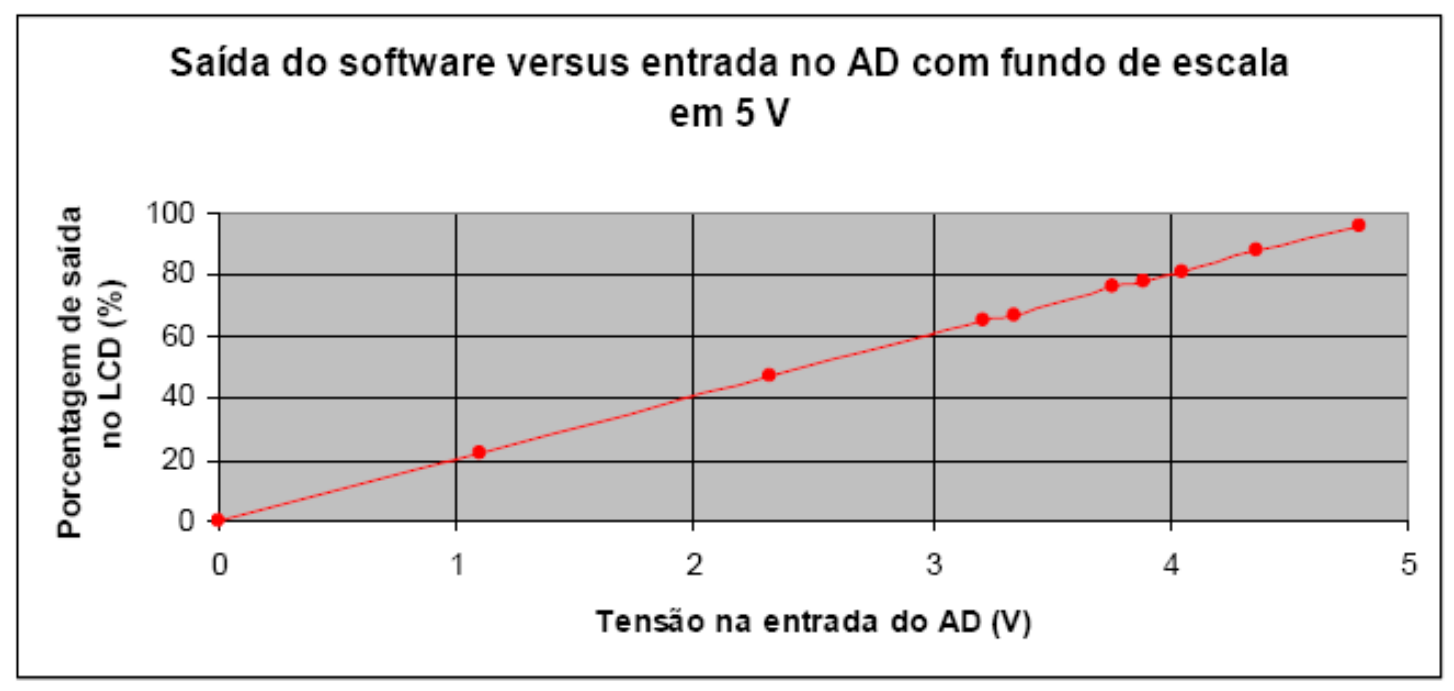

Figura 57: Saída do software versus entrada no AD. 


\section{Software}

A programação do 89552 foi feita em linguagem $C$ através da interface IAR mostrada na Figura 58. Pelo software é possível compilar o programa e gerar o arquivo “.hex”, que é necessário para a gravação do microcontrolador.

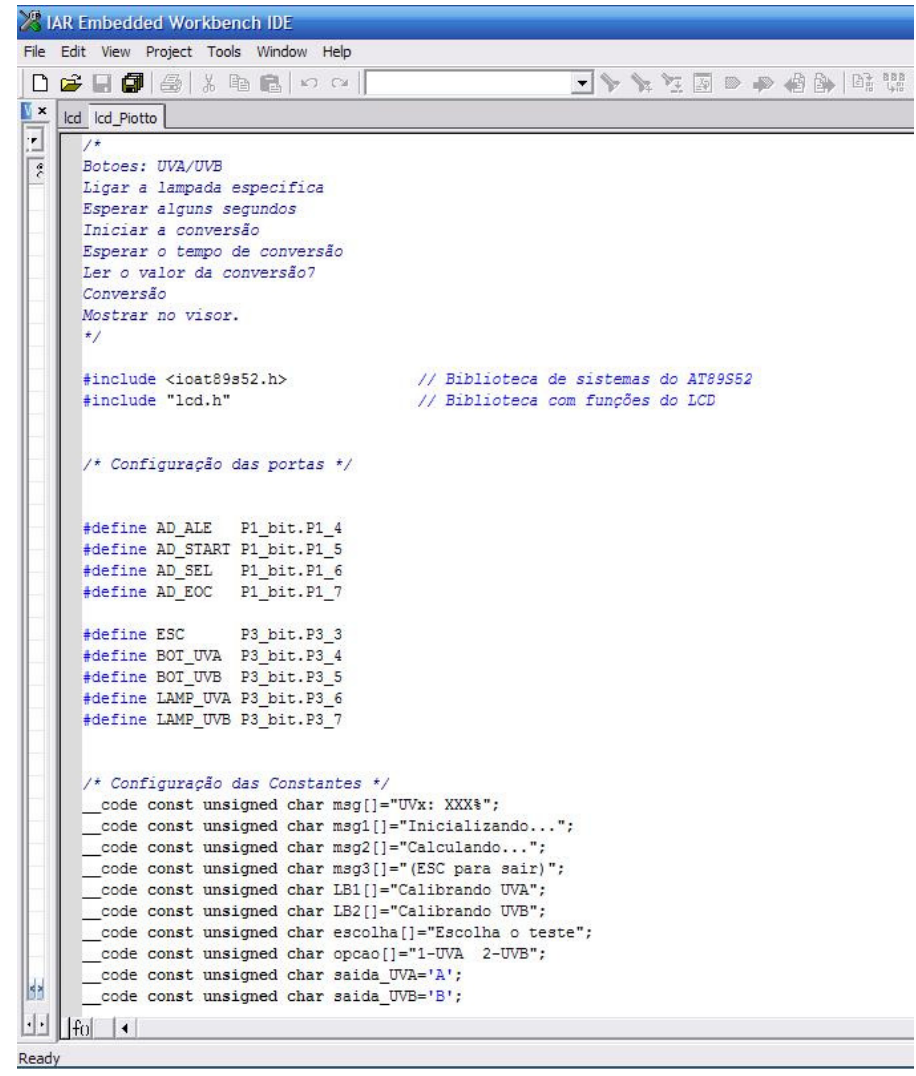

Figura 58 - Interface de programação IAR.

O software pode ser dividido em 04 blocos básicos:

1. Biblioteca de escrita no LCD

2. Controle de acionamento das lâmpadas

3. Aquisição do sinal do AD

4. Processamento da leitura do AD para impressão no display LCD 


\section{Controle do Display}

Para facilitar o uso do display de LCD foi escrita uma biblioteca em C exclusivamente para tal fim. Isso faz com que o programa principal torne-se mais enxuto e modularizado.

A seguir a biblioteca criada para a utilização do LCD comentada detalhadamente. A biblioteca abaixo pode ser utilizada também para displays com 4 linhas.

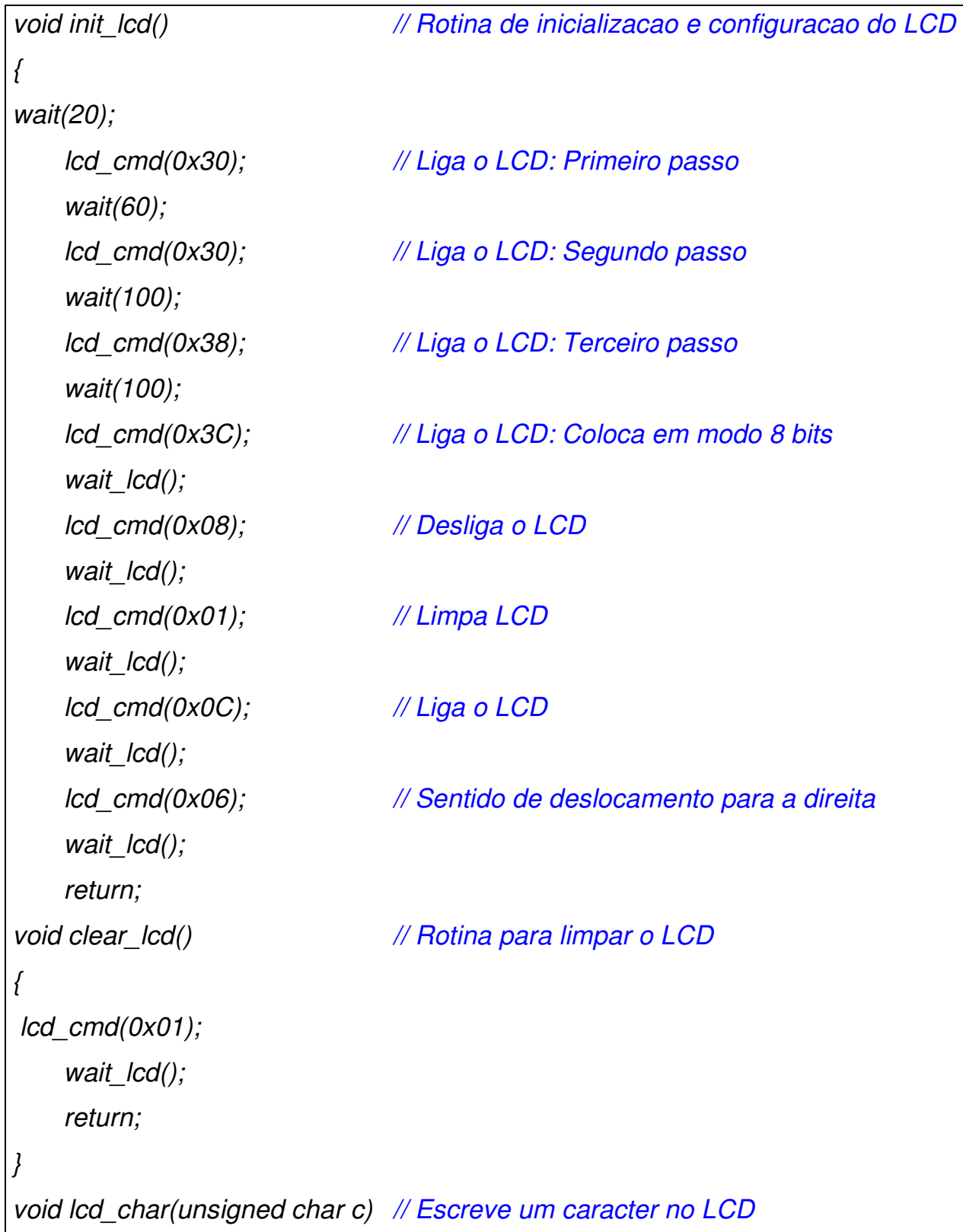




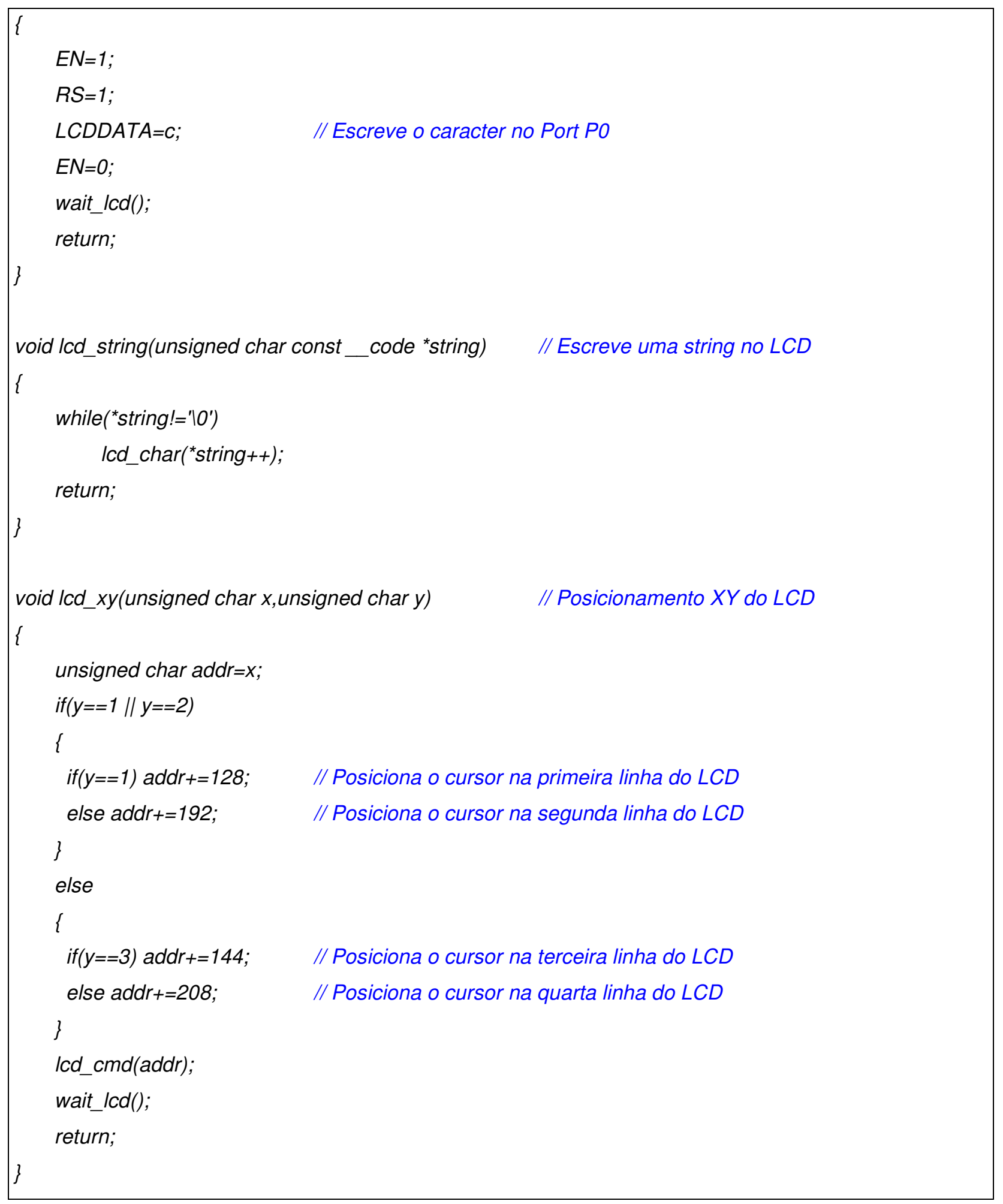




\section{Controle do Conversor A/D}

Para realizar o controle do conversor $A D$ deve-se atentar ao diagrama de tempos do conversor $A D$, exibido na Figura 54.

A função a seguir seleciona a entrada analógica que se deseja converter para digital (pulso no pino ALE). Inicia-se a conversão (pulso no pino START), espera o fim da conversão (pino EOC) e armazena o resultado em uma variável (AD_RESP).

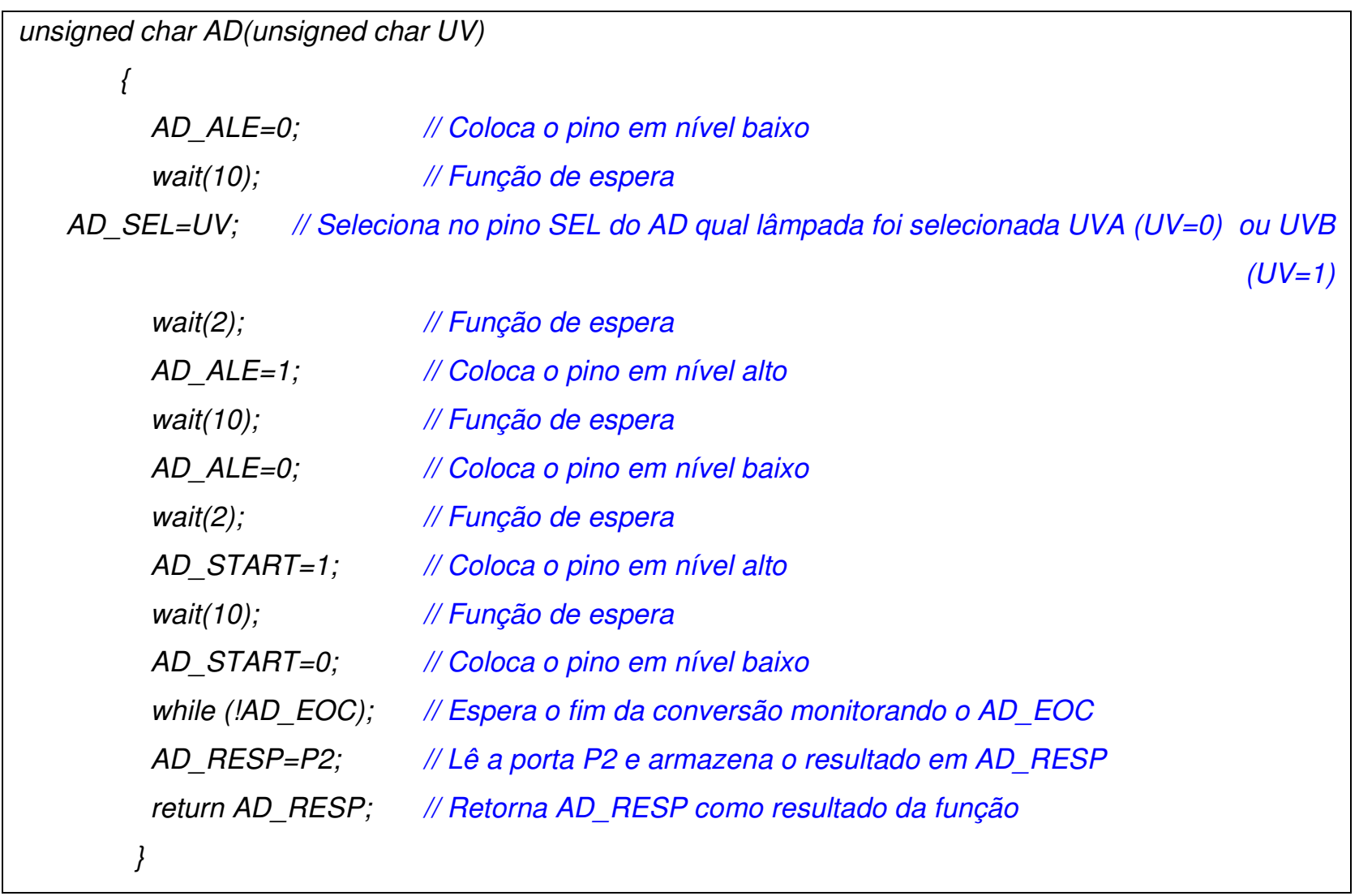




\section{Sub-rotinas adicionais utilizadas}

As sub-rotinas utilizadas no software estão comentadas em azul dentro do programa e explicadas individualmente para um melhor entendimento.

As sub-rotinas realizam as seguintes etapas:

1. Subrotina Executa:

a. Faz a leitura de qual botão foi pressionado, o de UVA ou o UVB;

b. Limpa o LCD;

c. Escreve a msg "Calculando..." no display;

d. Acende a lâmpada de UVA ou de UVB de acordo com o botão pressionado;

e. Atraso de 4 segundos;

f. Chama a sub-rotina AD para o conversor iniciar a conversão e armazena o resultado na variável val;

2. Sub-rotina para Cálculos de ajuste:

a. Multiplica o valor lido do AD por 100, devido a problemas de arredondamento, pois apesar do microcontrolador ser programado em $\mathrm{C}$, este não considera casas decimais nos cálculos;

b. Divide o valor obtido, quando o botão para calcular foi apertado pelo valor de fundo de escala adquirido quando o equipamento foi iniciado sem lente alguma. A partir disso trabalha-se com um valor normalizado, facilitando assim a impressão em porcentagem do valor de proteção da lente;

c. Calcula-se o valor da centena dividindo o valor normalizado por 100. Esse valor pode ser zero ou um. Será zero quando a lente não tiver proteção e deixar passar $100 \%$ dos raios de UV e será zero quando ela possuir algum tipo de filtro.

d. O valor da dezena é calculado fazendo a divisão do valor normalizado por 10. Como o microcontrolador não considera as casas decimais, 
realizando-se a subtração de dez vezes o valor da centena, tem-se o valor da dezena.

e. O valor a unidade é calculado com o valor total subtraindo-se 100X o valor da centena, subtraindo-se 10X o valor da unidade. Com isso, tem-se o valor porcentual para ser enviado ao LCD.

f. Corrige os valores para o número correspondente na tabela ASCII para serem impressos no LCD.

Exemplo de cálculos de ajuste:

Valor de fundo de escala: 5

Valor lido pelo AD após a inserção da lente: 2,1

Normalização:

$$
\frac{2,1}{5}=0,42
$$

Resultado da multiplicação por 100:

$$
0,42 \times 100=40
$$

Cálculo da centena da porcentagem sem considerar casas decimais:

$$
\frac{42}{100}=0
$$

Cálculo da unidade da porcentagem sem considerar casas decimais:

$$
\frac{42}{10}-10 \times 0=4
$$

Cálculo da centena da porcentagem sem considerar casas decimais:

$$
42-(100 \times 0+10 \times 4)=2
$$

Portanto, quando o microcontrolador exibir no LCD o resultado da conversão, esta será $42 \%$, que é o valor correto de acordo com os valores citados no exemplo.

3. Sub-rotina para Apresentação do resultado no LCD:

a. Escreve no LCD a máscara UVx: XXX\% para ser substituída posteriormente pelos valores. Essa fase é executada tão rapidamente, que não é perceptível ao usuário os valores XXX. 
b. Posicionamento do cursor no display de LCD para impressão do tipo de UV (A ou B). Nessa etapa o UVx será substituído por UVA ou UVB.

c. Posicionamento do cursor no display de LCD para impressão dos dígitos da centena, dezena e unidade no display. Nessa etapa o XXX\% será substituído pelo valor correto da porcentagem.

4. Sub-rotina com Procedimento para sair da rotina "Executa":

a. Posiciona o cursor na segunda linha;

b. Escreve a mensagem: "Pressione ESC para sair";

c. Loopimg para ficar aguardando o usuário apertar o botão ESC;

d. Ao pressionar o botão ESC, o microcontrolador limpará o display de LCD e escreverá as instruções para o usuário escolher o tipo de teste que deseja fazer na próxima medição.

A seguir, na Tabela 9 está exposta, em detalhes, a lista de comandos do programa, com os respectivos comentários.

Tabela 9: Linhas de comando do programa, com comentários

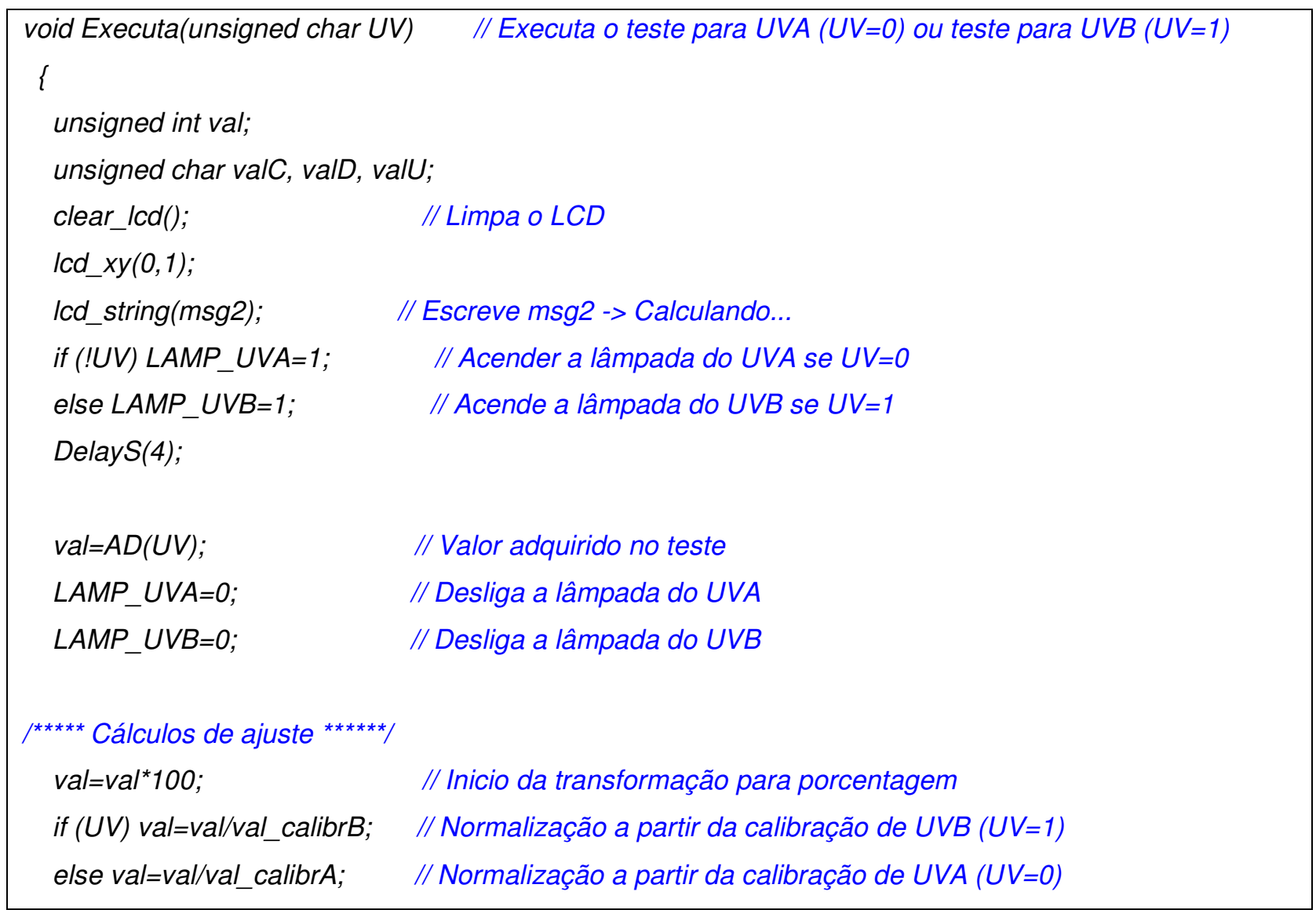




\begin{tabular}{|c|c|}
\hline $\mathrm{valC}=\mathrm{val} / 100$ & // Valor da centena \\
\hline val $D=(v a l / 10)-10^{*} v a l C$ & // Valor da dezena \\
\hline valU=val-((100*valC)+(10*valD)); & // Valor da unidade \\
\hline valC $+=48$ & //Correção para a tabela ASCII \\
\hline val $+=48$ & //Correção para a tabela ASCII \\
\hline val $U_{+=48}$ & //Correção para a tabela ASCII \\
\hline \multicolumn{2}{|l|}{${ }^{*}$ Apresentação do resultado no LCD */ } \\
\hline clear_lcd(); & // Limpa o LCD \\
\hline Icd_string(msg); & // Escreve MSG-> UVx: XXX\% \\
\hline Icd_xy $(2,1)$ & // Posiciona o cursor \\
\hline if (UV) Icd_char(saida_UVB); & // Se for teste de UVB $(U V=1)$ \\
\hline else Icd_char(saida_UVA); & // Se for teste de UVA $(U V=0)$ \\
\hline Icd_xy $(5,1)$ & // Posiciona o cursor \\
\hline Icd_char(valC); & // Escreve o digito da centena \\
\hline Icd_char(valD); & // Escreve o digito da dezena \\
\hline Icd_char(valU); & // Escreve o digito da unidade \\
\hline \multicolumn{2}{|c|}{${ }^{*}$ Procedimento para sair da rotina Executa* } \\
\hline$I c d \_x y(0,2)$ & // Posiciona na segunda linha \\
\hline lcd_string(msg3); & // Escreve msg3 -> "[ESC para sair]" \\
\hline while(!ESC); & // Aguarda teclar o botao ESC para sair \\
\hline \multicolumn{2}{|l|}{ clear_lcd(); } \\
\hline \multicolumn{2}{|l|}{ Icd_xy $(0,1)$} \\
\hline Icd_string(escolha); & // Escreve escolha -> "Escolha o teste" \\
\hline \multicolumn{2}{|l|}{ Icd_xy $(0,2)$} \\
\hline Icd_string(opcao); & // Escreve opcao -> "1-UVA 2-UVB" \\
\hline
\end{tabular}




\section{Programa principal}

O programa principal está comentado em azul e faz menção às sub-rotinas explicadas anteriormente, como apresentado na Tabela 10.

Basicamente consiste em:

1. Zerar todas as variáveis do sistema;

2. Inicializar o LCD;

3. Ligar as lâmpadas de UV, por 20 segundos, para aquecimento;

4. Faz a leitura do AD para as lâmpadas de UVA e UVB, sem lente posicionada, e assume esse valor como fundo de escala;

5. Escreve as mensagens para o usuário selecionar o tipo de medida a ser selecionada;

6. Looping para detectar qual botão foi pressionado.

Tabela 10: Programa Principal

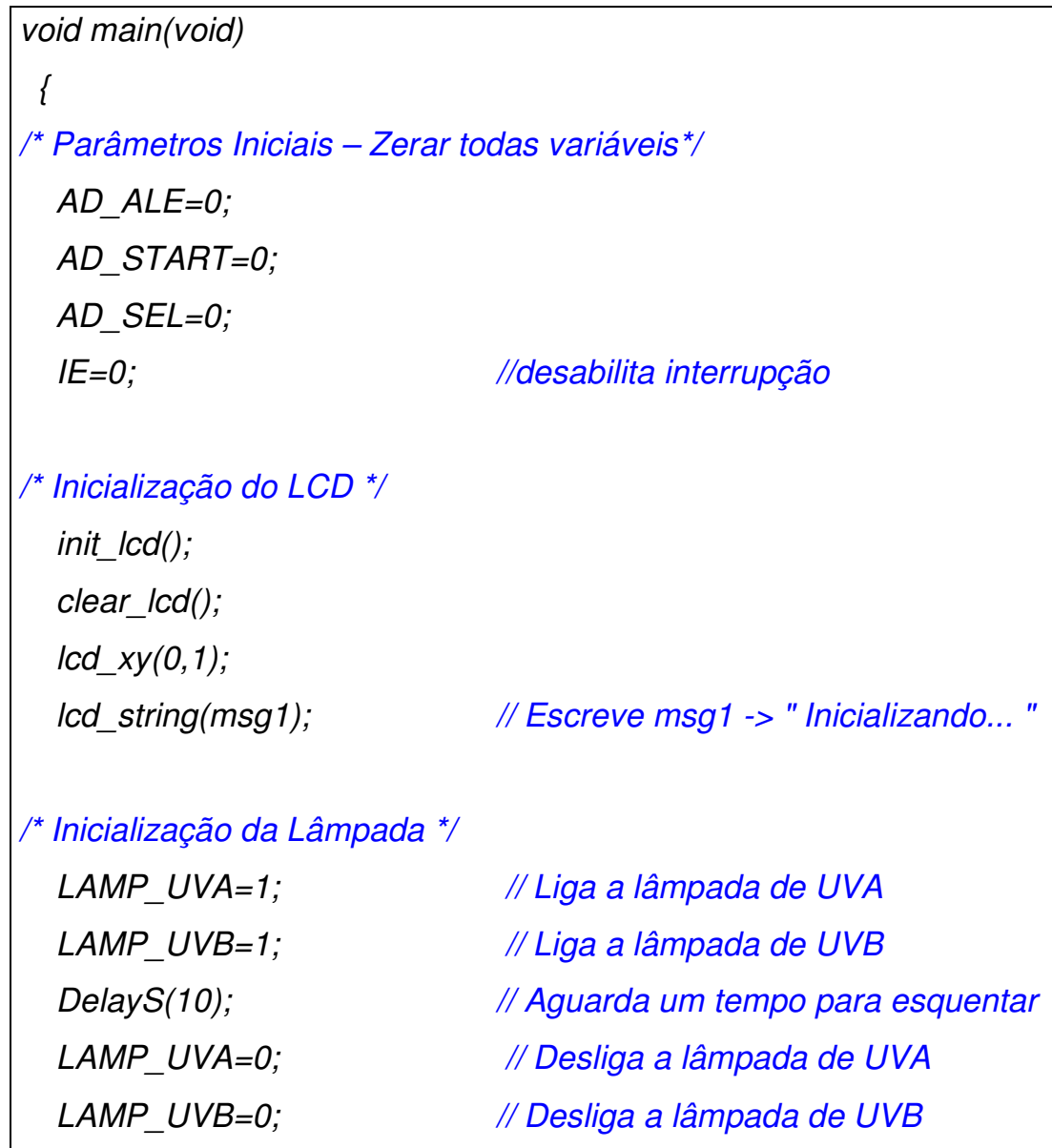


/ Calibração Lâmpada UVA */

DelayS(1);

clear_lcd();

Icd_xy $(0,1)$;

Icd_string(LB1); $\quad$ // Escreve LB1 -> " Calibrando UVA"

wait(150);

LAMP_UVA=1; $\quad$ // Liga a lâmpada de UVA

DelayS(3);

val_calibrA=AD(0); $\quad$ // Recebe o valor do $A D$ para ajuste de calibração de UVA (fundo de escala)

LAMP_UVA=0; $\quad$ // Desliga a lâmpada de UVA

* Calibração Lâmpada UVB */

DelayS(1);

clear_lcd();

Icd_xy $(0,1)$;

Icd_string(LB2); $\quad$ // Escreve LB1 -> " Calibrando UVB "

wait(150);

LAMP_UVB=1; $\quad$ // Liga a lâmpada de UVB

DelayS(3);

val_calibrB=AD(1); $\quad$ // Recebe o valor do $A D$ para ajuste de calibração UVB (fundo de escala)

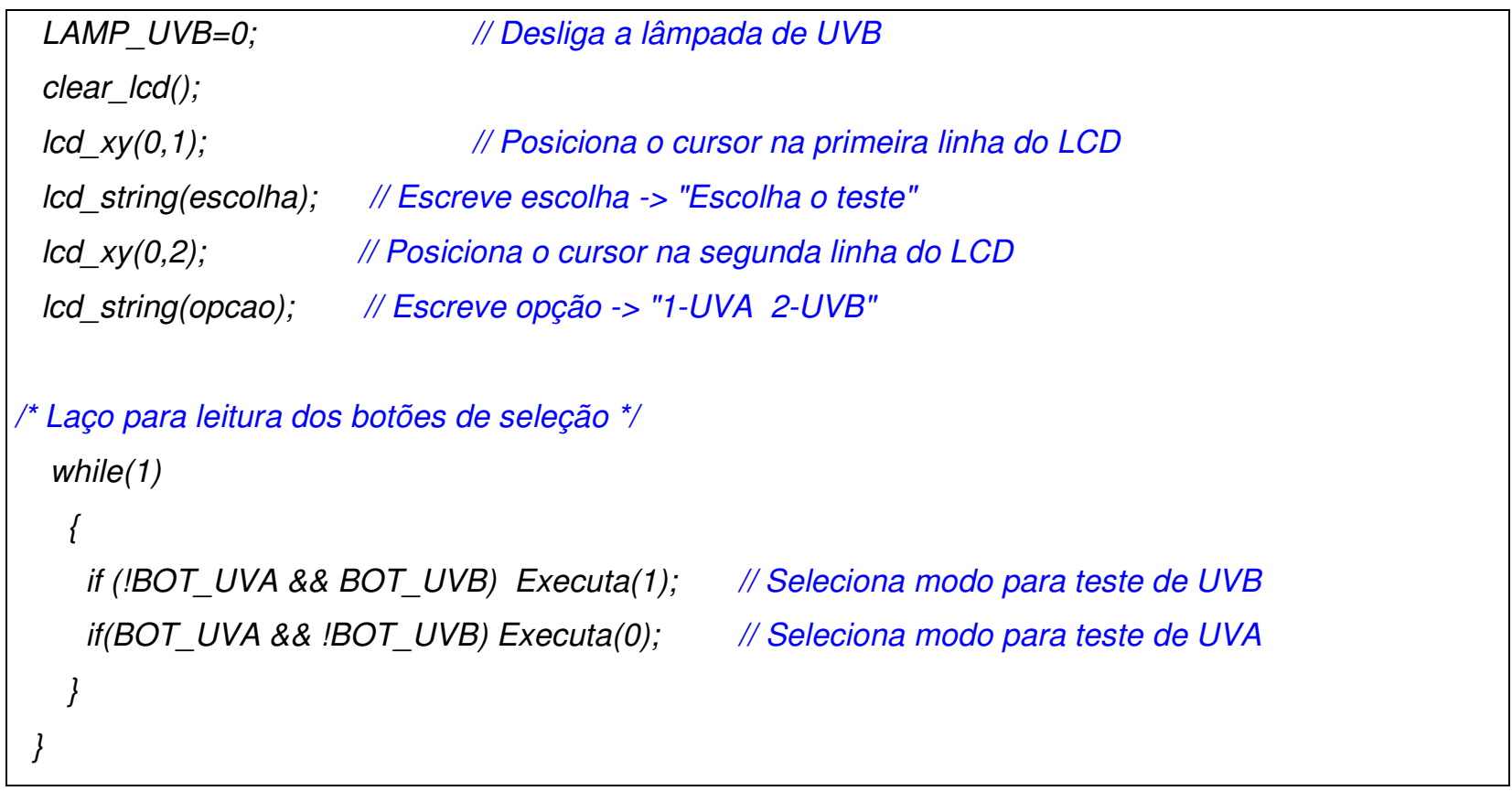




\section{Resultados}

Segundo dados do fabricante, o sensor tem um comportamento linear na relação da variação da intensidade de luz, com a variação de tensão de saída, como indica o gráfico da Figura 60.

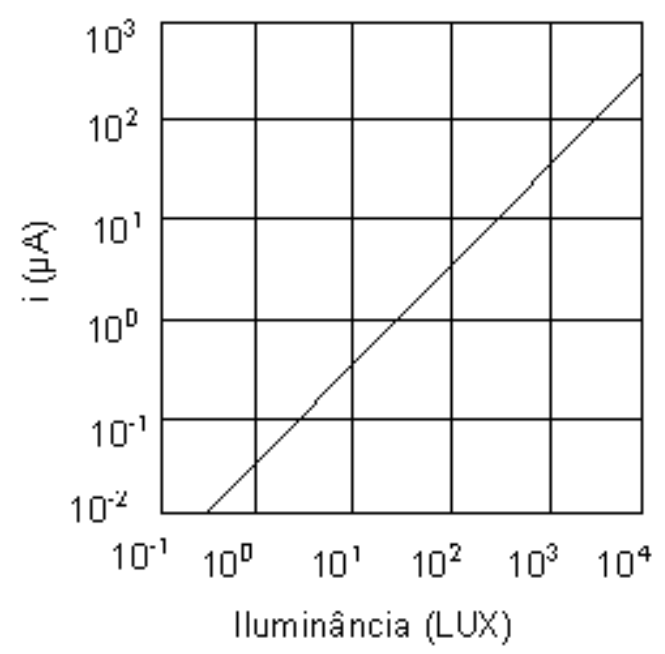

Figura 60: Variação da intensidade de luz, com a variação de corrente de saída - dados do fabricante do sensor OPT101.

As partes analógica e digital foram realizadas baseadas nesta linearidade. Através de testes em bancada de laboratório, verificou-se que sem amostra, ou seja, com a intensidade total de luz atingindo o sensor, este apresenta uma tensão de saída de aproximadamente $5 \mathrm{~V}$ e com obstrução total da luz no sensor, apresenta tensão nula.

Para testar o dispositivo de detecção e amplificação foi montado o circuito da Figura 61. 


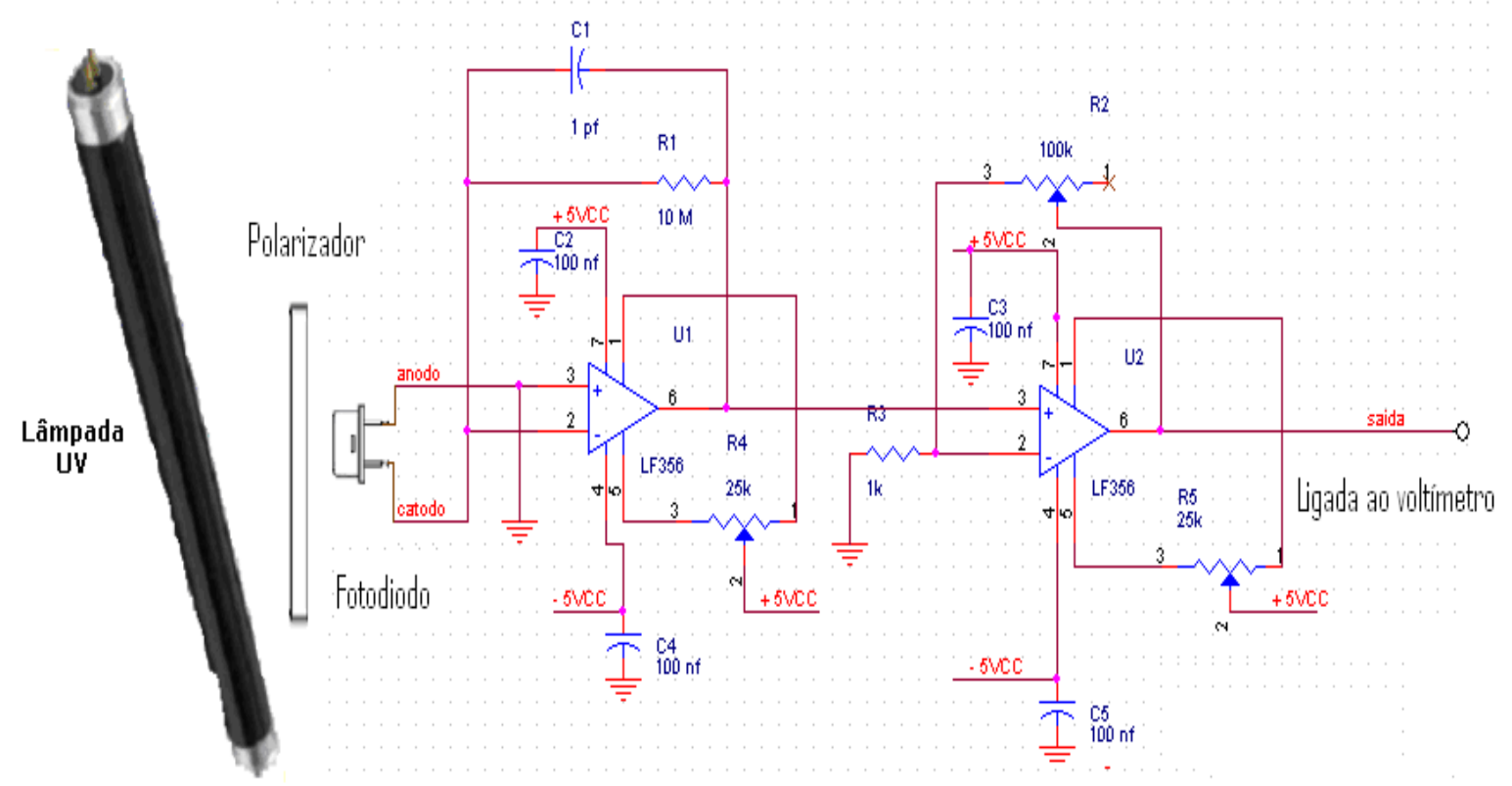

Figura 61: Circuito de detecção e amplificação de sinal.

A lâmpada ultravioleta foi acondicionada em uma caixa contendo um orifício de $3 \mathrm{~mm}$, de modo que a luz proveniente da lâmpada passasse através do mesmo, atravessasse o polarizador e finalmente atingisse com o fotodiodo.

A saída do amplificador foi ligada a um multímetro Minipa modelo ET-2076. Primeiramente, foi realizada uma medida com a lâmpada desligada a fim de fazer o ajuste de zero. Para isso, foi necessário ajustar os potenciômetros $R_{4}$ e $R_{5}$, que são responsáveis pelo ajuste de off-set dos amplificadores operacionais. Como o circuito lógico trabalha com nível TTL, isto é, tensão de alimentação de 5VCC, foi escolhida a tesão de $5 \mathrm{VCC}$ como tensão de referência do A/D. Logo o máximo de tensão na saída dos amplificadores era de 5VCC. . Para fazer essa calibragem foi ligada a lâmpada e retirado o polarizador, dessa forma toda luz que provinha da lâmpada atingia o fotodiodo. Através do potenciômetro $R_{2}$ foi ajustada a tensão para de modo que a tensão máxima fosse de 5VCC. Verificou-se que após fixado o valor de 5VCC a tensão não se mantinha constante chegando a medir tensões aleatórias entre OVCC e 8VCC. Foram adicionados capacitores cerâmicos de 100nf entre o terra e as alimentações dos circuitos integrados a fim de eliminar ruído, mas o problema continuou. Foram efetuados vários testes onde foi diagnosticado que o transformador 
da fonte induzia ruídos no circuito. O transformador da fonte foi isolado do circuito, mas o problema continuou. Como última tentativa foi eliminada a fonte ligada a rede $\mathrm{AC}$, que foi substituída por duas baterias de 9vcc.

Ao se ligar e desligar a lâmpada, para fazer os testes, percebeu-se que a lâmpada demanda 40s para atingir sua máxima potência, e que após atingida a potência máxima, esta decai até atingir um valor fixo. Para contornar esse problema foi implementado no software uma rotina de inicialização, para contagem de tempo, como segue:

AD_START=0;

$A D \_S E L=0$;

IE=0; //desabilita interrupção

/ Inicialização do LCD */

init_lcd();

clear_lcd();

lcd_xy $(0,1)$;

Icd_string(msg1); // Escreve msg1 -> " Inicializando... "

/* Inicialização da Lâmpada */

LAMP_UV=1; // Liga a lâmpada de UV

DelayS(40); // Aguarda um tempo para esquentar

LAMP_UV=0; // Desliga a lâmpada de UV

/ Calibração Lâmpada UV */

DelayS(1);

clear_lcd();

lcd_xy $(0,1)$;

Icd_string(LB1); // Escreve LB1 -> " Calibrando UV"

wait(150);

LAMP_UV=1; //Liga a lâmpada de UV

DelayS(3);

val_calibr $A=A D(0)$; // Recebe o valor do $A D$ para ajuste de calibração de UV

(fundo de escala)

LAMP_UVA=0; // Desliga a lâmpada de UVA

clear_lcd(); 
Icd_xy $(0,1)$; // Posiciona o cursor na primeira linha do $L C D$.

Ao se ligar o equipamento, o display apresenta a palavra "Inicializando" Somente quando a lâmpada estabilizar, é que o dispositivo estará pronto para efetuar medidas.

\section{Interface com usuário}

A interface entre o menu e o usuário é feita através de um de um display de LCD.

Ao ligar o equipamento o display exibirá ao usuário as mensagens:

- De inicialização do sistema - Figura 62: "Inicializando...”; Tem o intuito de aguardar a estabilização da lâmpada. Quando o sinal fica estável, nas últimas 100 medidas, o sistema prossegue;

- De calibração do sistema - Figura 63: "Calibrando UVA" e "Calibrando UVB". O sinal de cada sensor, com recepção de 100\% da luz emitida pela fonte é armazenado para poder realizar a medida naquele instante.

- De realização da medida - Figura 64: "Escolha o teste: 1. UVA; 2. UVB". Quando a fase de calibração estiver finalizada, o software aguardará um comando do usuário para selecionar o tipo de medição (UVA ou UVB) e então realizará a medida.

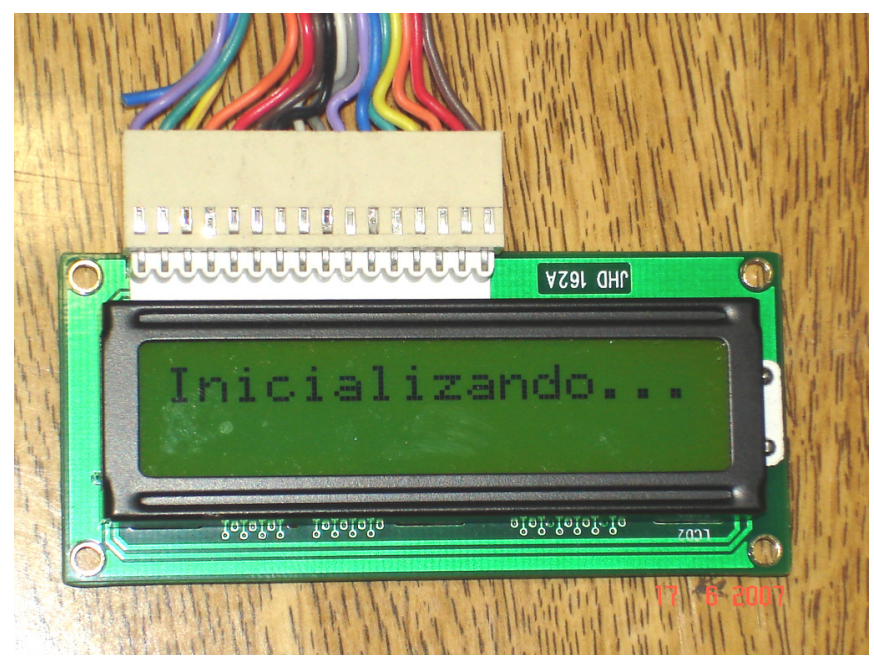

Figura 62 - Display com a mensagem de inicialização do sistema. 


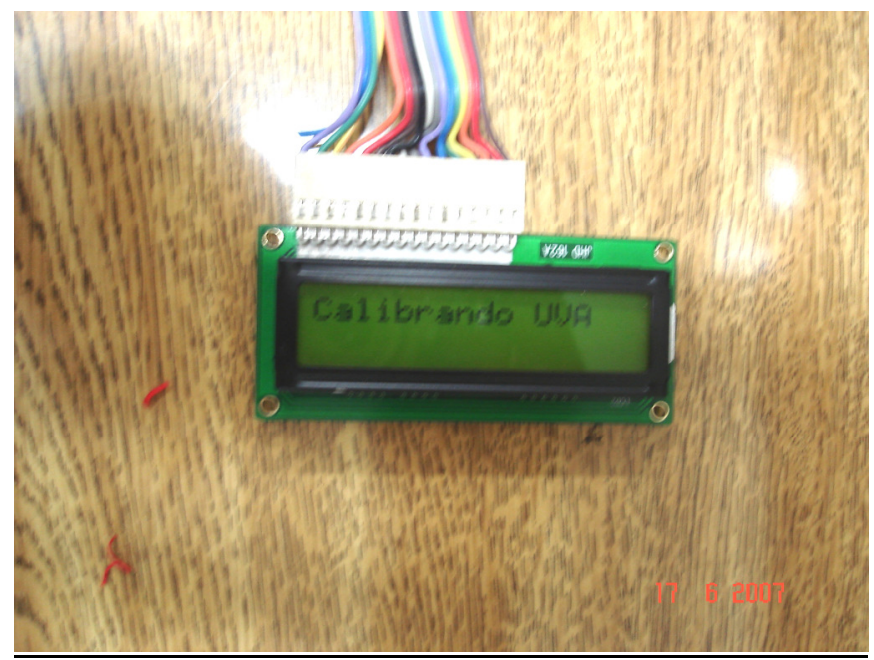

Figura 63 - Display com a mensagem de calibração do sistema

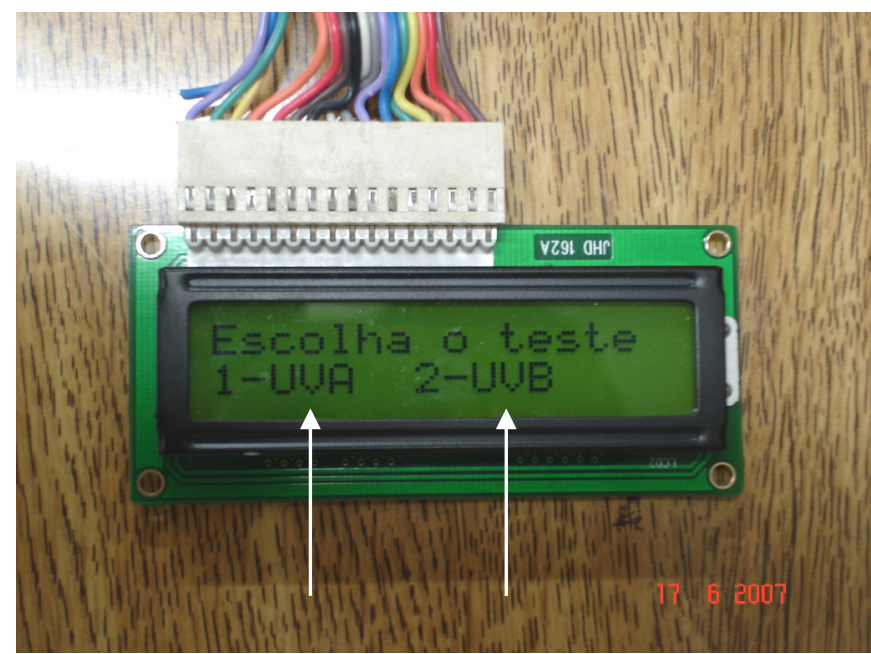

Figura 64 - Display exibindo a seleção de teste.

Após a seleção do teste e antes do valor em porcentagem exibido no display a mensagem "Calculando..." será exibida. Assim, o valor é apresentado para o usuário.

A interface com o usuário é realizada através de três chaves (switches), que no software são entendidas como: botões UVA, UVB e ESC. A seta na Figura 65 mostra as três chaves. 


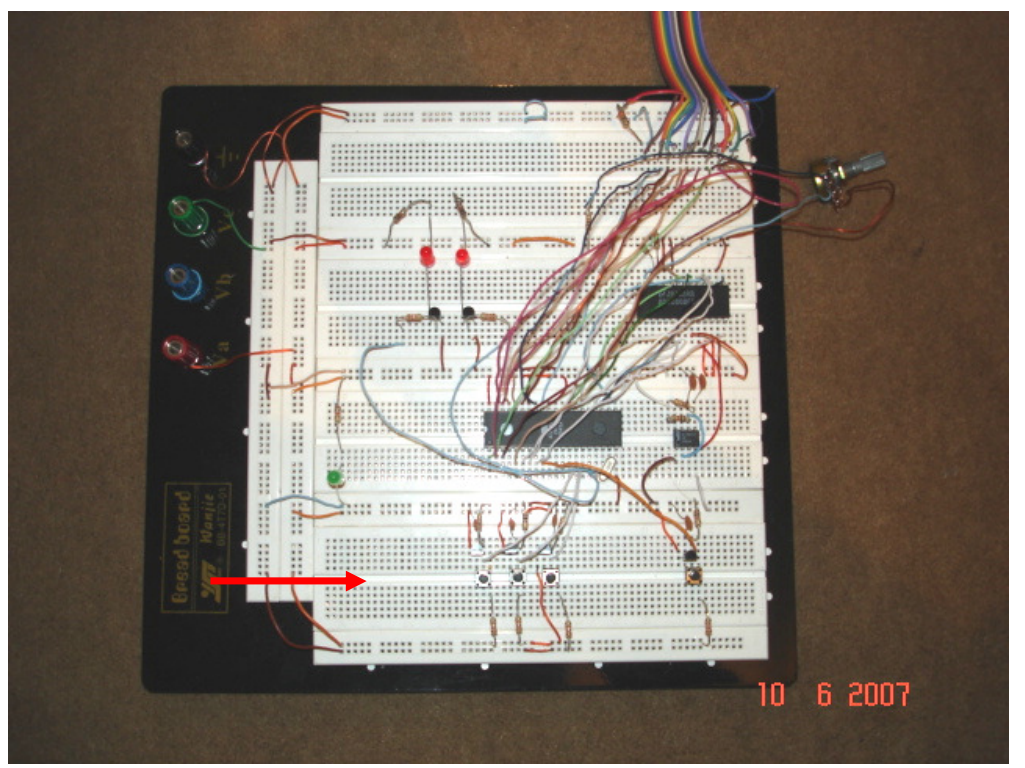

Figura 65: Parte do circuito digital utilizado na simulação 


\section{Calibração do sistema}

O equipamento está projetado para que tenha um tempo para estabilização da lâmpada de UV de 1 minuto, que é um tempo adequado para esse tipo de fonte de luz.

A calibração do sistema é realizada no instante em que o equipamento é ligado. Nesse momento, o microcontrolador aciona as duas lâmpadas, por 60s, e então, liga as fontes de UV separadamente, faz a leitura do AD, sem nenhuma lente inserida no circuito, e armazena o resultado como fundo de escala para calibração.

Como o fotodiodo é linear até a saturação, a porcentagem de proteção da lente é feita através de uma divisão entre o valor de fundo de escala armazenado sem a amostra e o valor lido após a inserção da amostra no sistema ótico.

O sistema foi calibrado com polarizadores e a Lei de Malus foi obedecida, como mostra o gráfico da Figura 66.

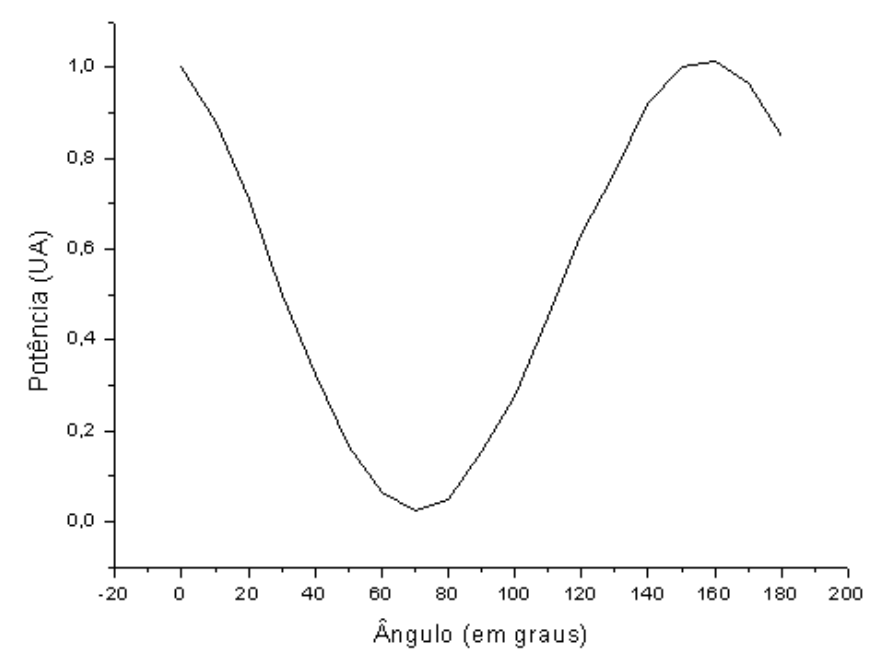

Figura 66: Medidas realizadas com polarizador no sistema para calibração. 


\section{Testes em óculos}

Foram realizados testes em 20 amostras de óculos, categoria 4, e comparadas ao espectrofotômetro Cary 17 - VARIAN.

O espectrofotômetro foi calibrado com Óxido de Hólmio e ajustado para a escala de 10nm de passos, conforme a norma NBR15111.

Quando a seleção foi para UVA em nosso protótipo, foi comparado com os valores dos pontos obtidos no espectrofotômetro, na região de $290 \mathrm{~nm}-310 \mathrm{~nm}$; e para UVB, na região de $320-380 \mathrm{~nm}$.

O fator de correlação entre o protótipo desenvolvido e o espectrofotômetro foi de 0,82 . 


\section{Discussão e Conclusão}

O circuito digital apresenta uma imprecisão devido ao conversor analógico digital de aproximadamente $10 \mathrm{mV}$, que representa um erro de aproximação menor do $1 \%$ nas medidas. Porém, o software embarcado no microcontrolador não imprime no display casas decimais.

Isto tem a implicação direta no fator de correlação entre este protótipo e o espectrofotômetro.

As flutuações da lâmpada também contribuem para a imprecisão, uma vez que a repetibilidade do sistema é de 90\%, em 20 medidas de uma mesma lente.

Assim, este projeto tornou-se um protótipo inicial de desenvolvimento de um sistema mais elaborado para que um medidor de radiações UVA e UVB portátil, possa estar a serviço da população em médio prazo.

Novos projetos para este medidor estão sendo implementados, como continuidade deste trabalho para se atingir este objetivo. 


\section{Bibliografia}

Atchison, A.; Smith, G.; (2000); Optics of the Human Eye, Ed. Butterworth-Heinemann,.

Beeson, S.; Mayer, J.W. (2008) - Patterns of Light Chasing the Spectrum from Aristotle to LEDs - Springer New York Publisher.

Blumenthaler, M.; Rehwald, W.; Ambach,: W.; (1985) "Seasonal variations of erythema dose at two alpine stations of different altitudes”, Arch. Met. Geoph. Biocl., série B, 35,389 .

Davis, J. K.; (1990) "The sunglass standard and its rationale" Optom. Vis . Sei., volume 67,414

Green, A. E. S., Cross, K. C.; Smith L. A. (1980) "Improved analytic characterization of ultraviolet skylight", Photochem. Photobiol., volume 31, 59.

H. L. Hoover, S. G. Marsaud (1985) "Calculating solar ultraviolet irradiation of the human cornea and responding required sunglass lens transmittance", Proceedings of the SPIE, Volume 601, Ophtalmic Physics, 140- 145.

H. L. Hoover. (1986) "Solar ultraviolet irradiation of the human cornea, lens and retina : Equations of ocular radiation", Appl. Opt, volume 25, 329.

Harm, W., (1980). "Biological effects of ultraviolet radiation" - IUPAB biophysics series Cambridge, Eng.; New York : Cambridge University Press, 216 p.

Hecht, E.; (1990) - Optics - New York, Addison-Wesley Publishing Company, $2^{\text {nd }}$ Edition.

Hoover, H. L.; (1987) "Sunglass, pupil dilation, and solar irradiation of the human lens and retina", Appl. Opt., 689

Koller, L. R., (1952). “Ultraviolet radiation” - New York : Wiley, 270p. 
NBR15111; (2004) "Proteção pessoal dos olhos - Óculos de sol e filtros de proteção contra raios solares para uso geral"

Piazena, H.; (1993) "Vertical distribution of solar irradiation in the tropical Chile Andes", Am. Soc Photobiol., Annual Meeting, Chicago.

Sliney, D. H., (2001) "Photoprotection of the eye - UV radiation and sunglasses" Journal of Photochemistry and Photobiology .v.64, pp. 166-175

Sliney, D.H., (1995). "UV radiation ocular exposure dosimetry" - Journal of Photochemistry and Photobiology, v.31, pp. 69-77.

Smith, K. C.; Sedra, A. S. (1999) Microeletrônica - $4^{\mathrm{a}}$ edição - Ed. Makron Books.

Vergaz, R. et al; (2002) "UV index experimental values during the years 2000 and 2001 from the Spanish broadband UVB radiometric network" Photochemistry and photobiology 76(2):181-7. 